ORNL/ER-322

LOCKHEED MARTINA

\section{ENVIRONMENTAL RESTORATION PROGRAM}

\section{Work Plan for the High Ranking Facilities Deactivation Project at Oak Ridge National Laboratory, Oak Ridge, Tennessee}

RECEIVED

AUf 20 1946

OSTI

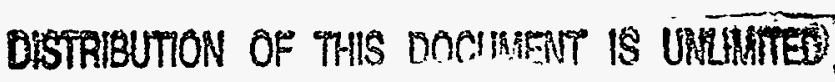

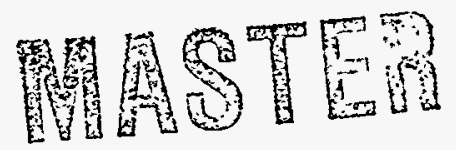

This document has been approved for release to the public by the ORNL Technical Information Officer. Date: $3 / 5 / 96$ 
Advanced Integrated Management Services, Inc. and Parsons Power, Inc.

contributed to the preparation of this document and should not be considered eligible contractors for its review.

This report has been reproduced directly from the best available copy.

Available to DOE and DOE contractors from the Office of Scientific and Technical Information, P.O. Box 62, Oak Ridge, TN 37831; prices available from 423-576-8401 (fax 423-576-2865).

Available to the public from the National Technical Information Service, U.S. Department of Commerce, 5285 Port Royal Rd., Springfield, VA 22161. 
Energy Systems Environmental Restoration Program

\author{
Work Plan for the High Ranking \\ Facilities Deactivation Project \\ at Oak Ridge National Laboratory, \\ Oak Ridge, Tennessee
}

\title{
Revision 1
}

Date Issued-March 1996

\author{
Prepared by \\ Advanced Integrated Management Services, Inc., \\ Oak Ridge, Tennessee \\ under subcontract 85X-HQG25 \\ and \\ Parson's Power, Inc., \\ Oak Ridge, Tennessee \\ under subcontract 1BX-GJS75C \\ Prepared for the \\ U.S. Department of Energy \\ Office of Environmental Management \\ under budget and reporting code EW 20 \\ Environmental Management Activities at \\ OAK RIDGE NATIONAL LABORATOR I \\ Oak Ridge, Tennessee 37831-6285 \\ managed by \\ LOCKHEED MARTIN ENERGY SYSTEMS, INC. \\ for the \\ U.S. DEPARTMENT OF ENERGY \\ under contract DE-AC05-84OR21400
}




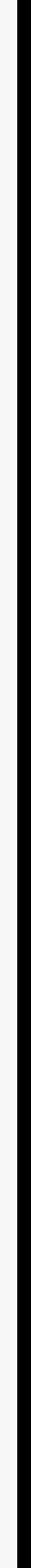




\section{DISCLAIMIER}

Portions of this document may be illegible in electronic image products. Images are produced from the best available original document. 


\section{CONTENTS}

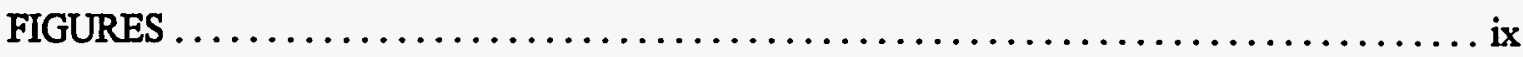

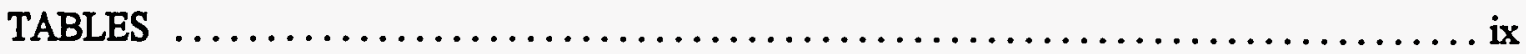

ABBREVIATIONS $\ldots \ldots \ldots \ldots \ldots \ldots \ldots \ldots \ldots \ldots \ldots \ldots \ldots \ldots \ldots \ldots \ldots \ldots \ldots \ldots \ldots \ldots$

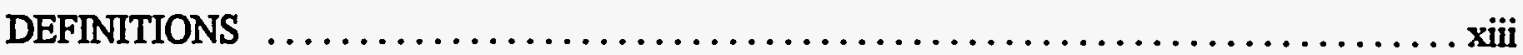

EXECUTIVE SUMMARY $\ldots \ldots \ldots \ldots \ldots \ldots \ldots \ldots \ldots \ldots \ldots \ldots \ldots \ldots \ldots \ldots \ldots \ldots \ldots$

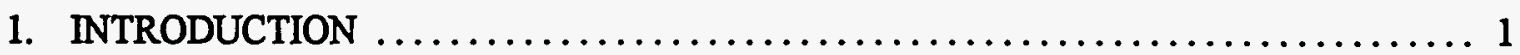

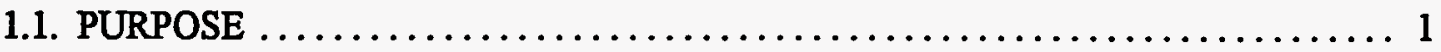

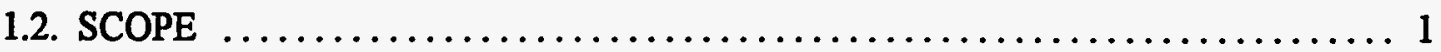

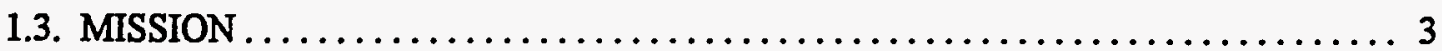

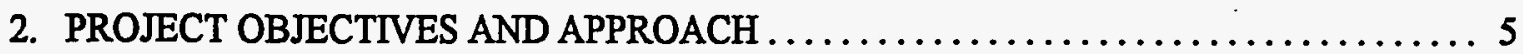

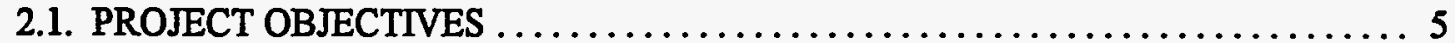

2.1.1. Environment, Safety, and Health Objectives $\ldots \ldots \ldots \ldots \ldots \ldots \ldots \ldots 6$

2.1.2. Compliance Objectives ............................ 6

2.1.3. EM-60/EM-40 Transition Objectives for Those Facilities Destined for D\&D . 6

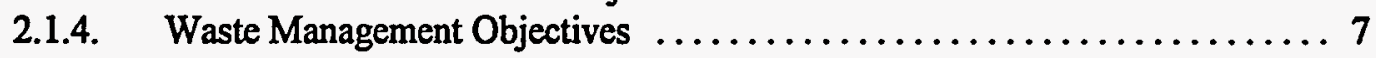

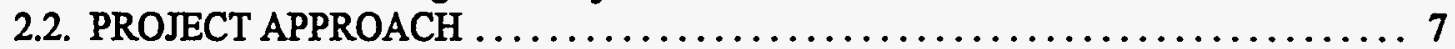

2.2.1. General Technical Requirements $\ldots \ldots \ldots \ldots \ldots \ldots \ldots \ldots \ldots \ldots \ldots$

2.2.2. Configuration Requirements $\ldots \ldots \ldots \ldots \ldots \ldots \ldots \ldots \ldots \ldots \ldots$

2.2.3. Hazardous and Radioactive Materials Removal/Stabilization Requirements .. 8

2.2.4. Surveillance and Maintenance Requirements $\ldots \ldots \ldots \ldots \ldots \ldots \ldots$. 9

2.3. FACILITY DEACTIVATION PROCESS $\ldots \ldots \ldots \ldots \ldots \ldots \ldots \ldots \ldots \ldots \ldots \ldots \ldots$

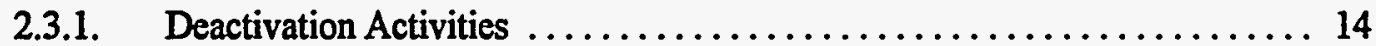

3. FACILITY SPECIFIC ACTIVITIES AND ENDPOINT CRITERIA $\ldots \ldots \ldots \ldots \ldots \ldots \ldots$

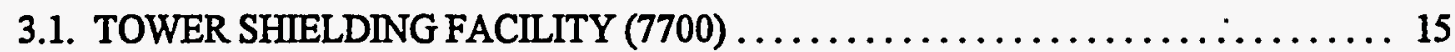

3.1.1. Building 7700 Tower Shielding Facility ................. 15

3.1.2. Building 7700A Big Beam Shield (Reactor Facility) ............ 22

3.1.3. Building 7700B Outside Source Storage Area (OSSA) ........... 23

3.1.4. Tower Shielding Civil Defense Facility (Bunker) $\ldots \ldots \ldots \ldots \ldots \ldots \ldots 24$

3.1.5. Building 7701 Tower Shielding Handling Pool $\ldots \ldots \ldots \ldots \ldots \ldots \ldots 24$

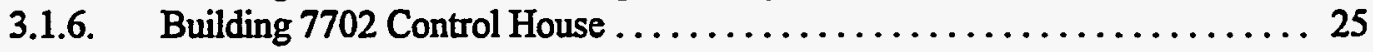

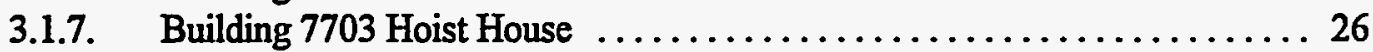

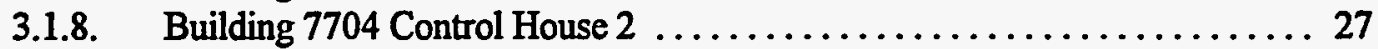

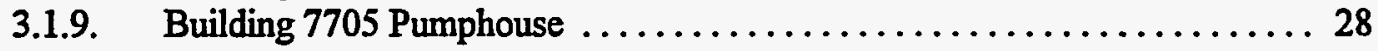

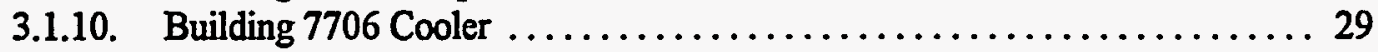

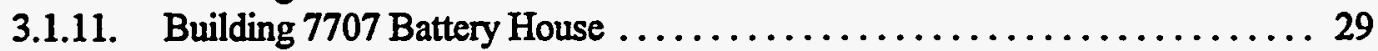

3.1.12. Building 7708 Butler Building ........................ 30

3.1.13. Building 7716 Tower Shielding Pool Pump and Filter House ......... 32 
3.2. HIGH RADIATION LEVEL ANALYTICAL FACILITY (3019B) $\ldots \ldots \ldots \ldots \ldots 32$

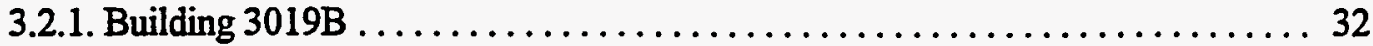

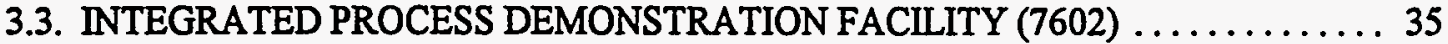

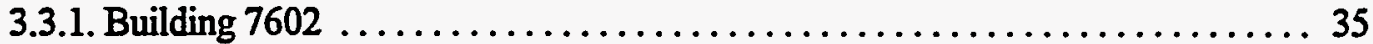

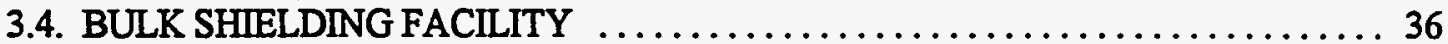

3.4.1. Building $3010-$ Bulk Shielding Facility $\ldots \ldots \ldots \ldots \ldots \ldots \ldots \ldots \ldots$

3.4.2. Building 3004 Water Demineralizer ........................ 40

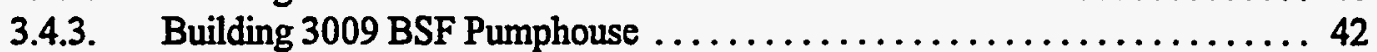

3.4.4. Building 3088 Storage Bulk Shielding Facility $\ldots \ldots \ldots \ldots \ldots \ldots \ldots 43$

3.4.5. Building 3101 Storage Shed Bulk Shielding Facility $\ldots \ldots \ldots \ldots \ldots \ldots 43$

3.4.6. Building 3117 BSF Cooling Tower .................... 45

3.4.7. Tank A-1204 Liquid Nitrogen Tank .................... 46

3.4.8. Tank 13822 Liquid Helium Tank ........................ 46

3.4.9. Building 3098 BSF Filter Facility $\ldots \ldots \ldots \ldots \ldots \ldots \ldots \ldots \ldots \ldots \ldots$

3.4.10. Building 3119 Heat Exchanger and Pumphouse $\ldots \ldots \ldots \ldots \ldots \ldots . \ldots 4$

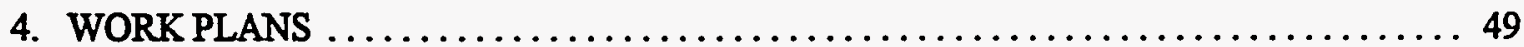

4.1. WORK BREAKDOWN STRUCTURE $\ldots \ldots \ldots \ldots \ldots \ldots \ldots \ldots \ldots \ldots \ldots \ldots \ldots$

4.2. PROJECT BASELINE SCHEDULE $\ldots \ldots \ldots \ldots \ldots \ldots \ldots \ldots \ldots \ldots \ldots \ldots \ldots \ldots$

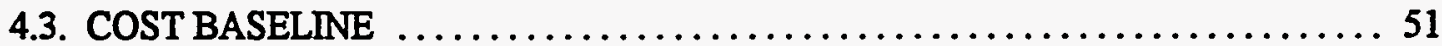

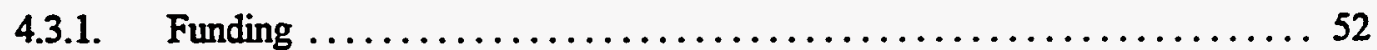

4.4. PROJECT ORGANIZATION AND RESPONSIBILITIES $\ldots \ldots \ldots \ldots \ldots \ldots \ldots \ldots$

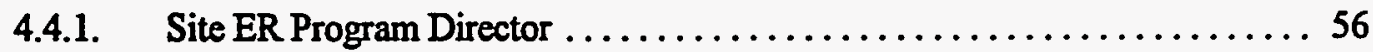

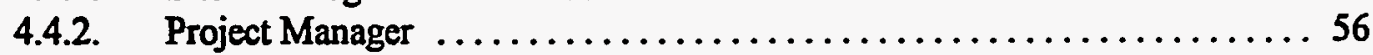

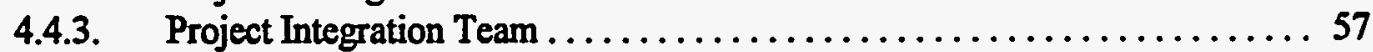

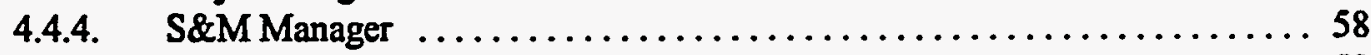

4.4.5. Deactivation/Compliance Activities Manager ................ 59

4.4.6. Health Physics Support .......................... 59

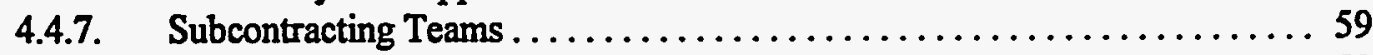

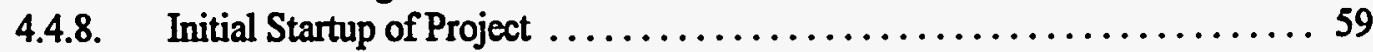

4.5. KEY PROJECT ASSUMPTIONS $\ldots \ldots \ldots \ldots \ldots \ldots \ldots \ldots \ldots \ldots \ldots \ldots \ldots \ldots \ldots \ldots \ldots \ldots \ldots \ldots$

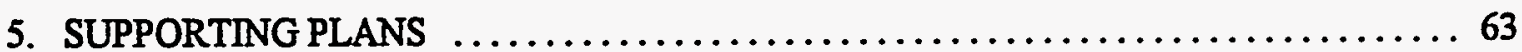

5.1. SURVEILLANCE AND MAINTENANCE PLAN DEVELOPMENT $\ldots \ldots \ldots \ldots 63$

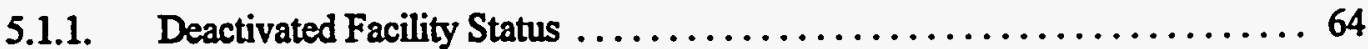

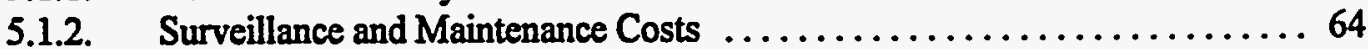

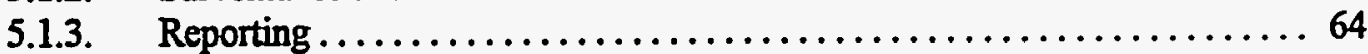

5.2. SAFETY DOCUMENTATION PLAN $\ldots \ldots \ldots \ldots \ldots \ldots \ldots \ldots \ldots \ldots \ldots \ldots \ldots$

5.2.1. Status of Existing Safety Documentation .................. 64

5.2.2. Unreviewed Safety Question Determination Process and Status .........65 65

5.2.3. Description of Problem Safety Summary Report .............. 65

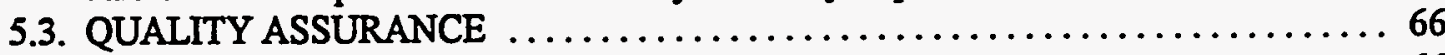

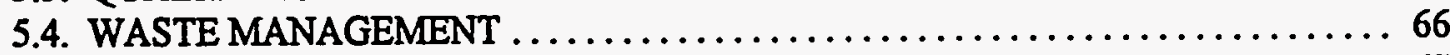

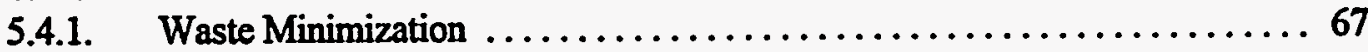

5.5. NATIONAL ENVIRONMENTAL POLICY ACT DOCUMENTATION . . . . . . 67

5.6. ENVIRONMENT, SAFETY, AND HEALTH $\ldots \ldots \ldots \ldots \ldots \ldots \ldots \ldots \ldots \ldots \ldots$

5.7. DOCUMENTATION AND RECORDS $\ldots \ldots \ldots \ldots \ldots \ldots \ldots \ldots \ldots \ldots \ldots \ldots$ 
5.7.1. Field Documentation Forms $\ldots \ldots \ldots \ldots \ldots \ldots \ldots \ldots \ldots \ldots, 68$

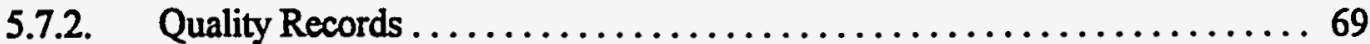

Appendix A. DESCRIPTION AND HISTORY OF FACILITIES $\ldots \ldots \ldots \ldots \ldots \ldots \ldots$ A-1

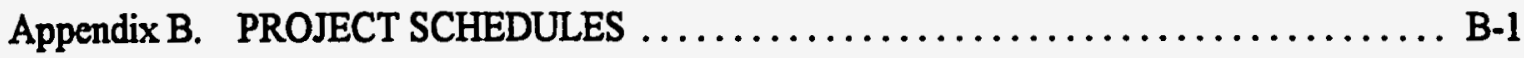

Appendix C. PROJECT COST ESTIMATES $\ldots \ldots \ldots \ldots \ldots \ldots \ldots \ldots \ldots \ldots \ldots \ldots \ldots \ldots \ldots \ldots$

Appendix D. PROJECT SURVEILLANCE AND MANTENANCE ACTIVITIES ........ D-1

Appendix E. FY 1996 PLANNED MAJOR HIGHLIGHTS $\ldots \ldots \ldots \ldots \ldots \ldots \ldots \ldots$ E-1 


\section{FIGURES}

ES-1. High Ranking Facilities Deactivation Project-schedule ................ xvii

2.1. High Ranking Facilities Deactivation Project—deactivation process for surplus facilities 11

4.1. High Ranking Facilities Deactivation Project-project organization $\ldots \ldots \ldots \ldots \ldots \ldots 5$

4.2. High Ranking Facilities Deactivation Project-problem-solving methodology ....... 58

\section{TABLES}

ES-1. High Ranking Facilities Deactivation Project-cost summary $\ldots \ldots \ldots \ldots \ldots \ldots \ldots$ xvii

1.1 High Ranking Facilities Deactivation Project-scheduled facilities $\ldots \ldots \ldots \ldots \ldots \ldots . \ldots \ldots$

4.1. High Ranking Facilities Deactivation Project-work breakdown structure $\ldots \ldots \ldots \ldots 50$

4.2 High Ranking Facilities Deactivation Project-milestones $\ldots \ldots \ldots \ldots \ldots \ldots \ldots \ldots$

4.3 High Ranking Facilities Deactivation Project-activities for FY $1996 \ldots \ldots \ldots \ldots \ldots . . \ldots 3$

5.1 Surveillance and maintenance costs .......................... 64 


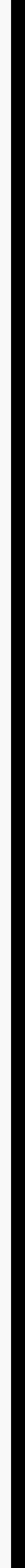




\section{ABBREVIATIONS}

ADS

AEC

BSF

BSR

CERCLA

CFC

CFR

CX

D\&D

DOE

DOT

EM-40

EM-60

EPA

ER

ERDA

ES\&H

FMC

FT\&M

FY

FFA

HAZWOPER

HEPA

HFIR

HPRR

HQ

HRFDP

HRLAF

HSD

HVAC

LCD

LLLW

LTI

LTNIF

LWBR

MOA

MTR

NE

NEPA

NRC

ORNL

ORO

ORR
Activity Data Sheet

Atomic Energy Commission

Bulk Shielding Facility

Bulk Shielding Reactor

Comprehensive Environmental Response, Compensation, and

Liability Act

chlorofluorocarbons

Code of Federal Regulations

categorical exclusion

decontamination and decommissioning

U.S. Department of Energy

U.S. Department of Transportation

U.S. Department of Energy Headquarters Office of

Decontamination and Decommissioning

U.S. Department of Energy Nuclear Material and Facility

Stabilization Program

U.S. Environmental Protection Agency

Environmental Restoration (the Program)

Environmental Restoration and Development Administration

environment, safety, and health

facility management contractor

facility transfer and management

fiscal year

Federal Facility Agreement

hazardous waste operations and emergency response

high-efficiency particulate air

High Flux Isotope Reactor

Health Physics Research Reactor

U. S. Department of Energy Headquarters

High Ranking Facilities Deactivation Project

High Radiation Level Analytical Facility

hazards screening document

heating, ventilation, and air conditioning

Limiting Conditions for Operations Document

liquid low-level (radioactive) waste

Low Temperature Irradiation Facility

Low Temperature Neutron Irradiation Facility

Light Water Breeder Reactor

memorandum of agreement

Materials Test Reactor

Office of Nuclear Energy

National Environmental Policy Act

Nuclear Regulatory Commission

Oak Ridge National Laboratory

Oak Ridge Operations Office

operational readiness review 
OSHA

OSSA

PCA

PCBs

PEP

PIT

PSS

PUREX

QA

QA\&I

QC

RCRA

RDF

RP

RPSD

RRD

RTS

SEG

S\&M

SA

SAR

SDB

SLLW

SNAP

SRO

SRS

SSHASP

SST

SWSA

THOREX

TRU

TSCA

TSF

TSR

USQD

WBS
Occupational Safety and Health Administration

outside source storage area

pool critical assembly

polychlorinated biphenyls

project execution plan

project integration team

problem safety summary

Plutonium uranium extraction

quality assurance

quality assessment and inspection

quality control

Resource Conservation and Recovery Act

Radiochemical Development Facility

radiation protection

Robotics and Process Systems Division

Research Reactor Division

Radiochemical Technology Section

Scientific Ecology Group

surveillance and maintenance

safety assessment

safety analysis report

small disadvantaged business

solid low-level (radioactive) waste

space nuclear auxiliary power

senior reactor operator

Savannah River site

site-specific health and safety plan

safe, secure trailer

solid waste storage area

thorium extraction

transuranics

Toxic Substances Control Act

Tower Shielding Facility

Tower Shielding Reactor

unreviewed safety question determination

work breakdown structure 


\section{DEFINITIONS}

Ancillaries are supporting facilities, utilities, safety systems, and security systems that provide direct support and are solely dedicated to the operational aspects of the facility.

Hazardous Wastes are those that are designated hazardous by EPA regulations ( 40 CFR 261).

Operational Readiness Review is a structured method for determining that a project, process, or facility is ready to operate and occupy and includes, as a minimum, review of the readiness of the plant and hardware, personnel, and procedures. The review also includes a determination of compliance with ES\&H Orders.

Safety Analysis Report is a safety document providing a concise but complete description and safety evaluation of the site, the design, normal and emergency operation, potential accidents, and predicted consequences of such accidents, and the means proposed to prevent such accidents or mitigate the consequences of such accidents.

Safety Document is a document prepared specifically to assure that the safety aspects of part or all of the activities conducted at a reactor are formally and thoroughly analyzed, evaluated, and recorded (e.g., technical specifications, safety analysis reports, etc.)

Senior Reactor Operator is an individual certified by contractor management to operate or to direct the operation of a DOE-owned reactor.

Shutdown is that condition in which a reactor facility has ceased operation and DOE has declared officially that it does not intend to operate the reactor further.

Spent Nuclear Fuel is that which has been irradiated but has not been reprocessed to remove its constituent elements.

Standby is that condition in which a reactor facility is neither operable nor declared excess, and documentary authorization exists to maintain the reactor for possible future operation.

Surplus Facility is any facility or site (including equipment) that has no identified or planned programmatic use and is contaminated with radioactivity to levels that may require controlled access. 


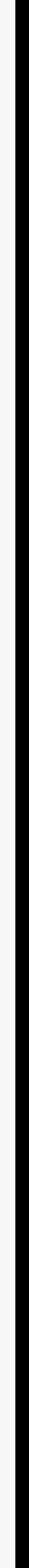




\section{EXECUTIVE SUMMARY}

The High Ranking Facilities Deactivation Project (HRFDP), commissioned by the U.S. Department of Energy Nuclear Materials and Facility Stabilization Program (EM-60), is to place four primary high-risk surplus facilities with 28 associated ancillary facilities at Oak Ridge National Laboratory (ORNL) in a safe, stable, and environmentally sound condition as rapidly and economically as possible. The facilities will be deactivated and left in a condition suitable for an extended period of minimized surveillance and maintenance (S\&M) prior to decontaminating and decommissioning (D\&D). These four facilities include two reactor facilities containing spent fuel. One of these reactor facilities also contains 55 tons of sodium with approximately 34 tons containing activated sodium-22 $\left({ }^{2} \mathrm{Na}\right), 2.5$ tons of lithium hydride $(\mathrm{LiH})$, approximately 100 tons of potentially contaminated lead $(\mathrm{Pb})$, and several other hazardous materials as well as bulk quantities of contaminated scrap metals. The other two facilities to be transferred include a facility with a bank of hot cells containing high levels of transferrable contamination and also a facility containing significant quantities of uranyl nitrate $\left[\mathrm{UO}_{2}\left(\mathrm{NO}_{3}\right)_{2}\right]$ and quantities of transferrable contamination.

These facilities have been identified as high risk facilities relative to other inactive/surplus facilities by EM-60. In FY 1994 and FY 1995, EM-60 initiated the Surplus Facilities Inventory and Assessment Project around the nation at all U.S. Department of Energy (DOE) sites. From this activity, a DOE-sponsored risk-ranking exercise for all facilities was performed. Those facilities that ranked at or above a certain score (determined by DOE) were considered high rankers and as such were directed to be transferred to EM- 60 by October 1, 1995.

\section{PROJECT INTEGRATION}

Completion of the HRFDP Project will result in significant life cycle S\&M cost savings for the facilities during future years due to removal and/or deactivation of hazardous and contaminated materials, thereby reducing S\&M requirements and documentation. The ultimate end goal is the transfer of these facilities to the D\&D program. The DOE Oak Ridge Operations (ORO) and EM-60 Headquarters, along with the HRFDP Manager, will evaluate currently identified deactivation activities to establish priority and to schedule and identify any additional activities necessary for transfer. Also, the HRFDP team will work with the U.S. Department of Energy Headquarters Office of Decontamination and Decommissioning (EM-40) to minimize life cycle costs in order to optimize the deactivation project and ensure a seamless transition to the EM-40 /D\&D program.

\section{BUSINESS APPROACH}

A major goal of the HRFDP is to subcontract as many activities as practical. The subcontracting strategy will incorporate performance-based incentivized contracts and privatization of stabilization activities where S\&M cost savings make this a feasible and attractive option. For example, by removing fuel from the two reactor facilities, it is anticipated an S\&M reduction of approximately $\$ 600 \mathrm{~K}$ per year could be achieved, compared with the cost for removing the fuel at an approximate cost of $\$ 2.5 \mathrm{M}$. In this instance, the payback to the defueling subcontractor would be realized in approximately four years.

The HRFDP has adopted the strategy of identifying deactivation and S\&M activities based on regulatory drivers, anticipated return on investment (dollars spent compared to reduction of life cycle costs), and lowering life cycle S\&M costs while always maintaining an adequate safety envelope. 


\section{INTRODUCTION}

\subsection{PURPOSE}

This work plan, commissioned by the U.S. Department of Energy Nuclear Materials and Facility Stabilization Program (EM-60), documents the objectives, technical requirements, and detailed work plans-including preliminary schedules, milestones, and conceptual FY 1996 cost estimates-for the High Ranking Facilities Deactivation Project (HRFDP) at Oak Ridge National Laboratory (ORNL). This plan has been developed by the Environmental Restoration (ER) Program of Lockheed Martin Energy Systems (Energy Systems) for the U.S. Department of Energy (DOE) Oak Ridge Operations Office (ORO).

\subsection{SCOPE}

In 1994, DOE completed an assessment of surplus facilities at each DOE site in the nation. Each surplus facility was then categorized according to a DOE-specified risk profile. Facilities were ranked with classifications of "high," "medium," or "low" risk by DOE. At ORNL, facilities ranked with a high risk classification have been incorporated into HRFDP by direct order from EM-60 Headquarters with the expressed objective of preparing these facilities to meet the requirements for deactivation and eventual transfer to the U.S. Department of Energy Headquarters Office of Decontamination and Decommissioning (EM-40/D\&D) Program for final disposition.

Four major facilities and their 28 ancillaries are currently included within HRFDP, as listed in Table 1.1. A description of each facility and all associated ancillary facilities is contained in Appendix A. To complete its mission, HRFDP must execute those activities required to perform deactivation, reduce surveillance and maintenance (S\&M) costs, and place each facility and its ancillaries in a safe shutdown condition. A deactivated, shutdown facility is one in which (1) hazardous materials, waste, and transferrable radioactive contamination have been removed from accessible areas; (2) containment structures have been checked or have been restored to sound physical condition; (3) energy sources in the facility have been de-energized to the maximum extent practical; (4) use and occupancy of the facility have been terminated; (5) the facility is structurally sound and weather tight; and (6) routine S\&M activities have been reduced to the lowest level practicable to maintain the facility in a structurally safe and sound condition while maintaining an adequate safety envelope and managing current and future uncertainties and risks.

This project includes identification of all known activities required to achieve these conditions and will manage their execution according to this plan and within the memoranda of agreement (MOAs) developed by DOE Headquarters and local offices. Existing building-specific procedures will be utilized and modified as required to conform to ER/DOE policies, practices, and procedures where necessary. Because of the complexity and age of the facilities, many uncertainties exist as to their condition. These unknowns will be managed accordingly and will likely result in future revisions to this work plan. 
Table 1.1. High Ranking Facilities Deactivation Project—scheduled facilities

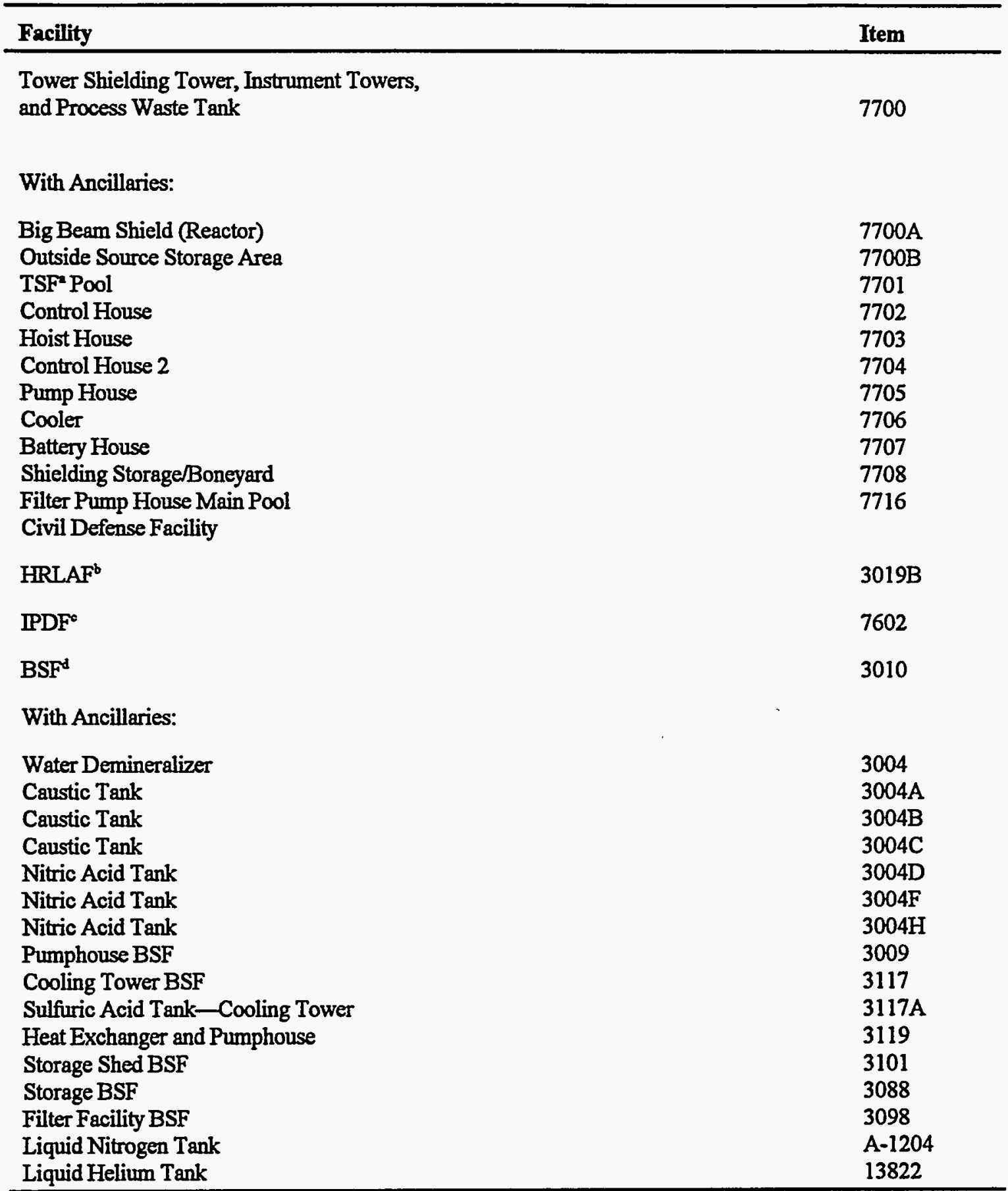

'TSF (Tower Shielding Facility, 'HRLAF (High Radiation Level Analytical Facility); TPDF (Integrated Process Demonstration Facility); BSF (Bulk Shielding Facility) 


\subsection{MISSION}

This planning document is intended to act as the initial guiding document for the creation and operation of HRFDP. Planning activities to follow provide the foundation and execution for the life cycle of the project. The overall mission of this plan is to deactivate the ORNL surplus facilities considered to be high risk to the environment and to worker health and safety and place them in a suitable condition for an extended period of rectuced S\&M costs. This project will also ensure an adequate safety envelope operating under-and complying with-appropriate state, federal, and local regulations; DOE Orders; and contractual agreements.

In pursuing this overall mission, the project will also

- establish a baseline S\&M program consistent with pre- and post-deactivation facility requirements;

- coordinate with EM-40 to facilitate acceptance and ultimate transfer of HRFDP facilities into the EM-40 D\&D program following deactivation, with a major goal of reducing life cycle S\&M costs;

- minimize waste generation during S\&M and deactivation activities with an emphasis on recycling and/or reuse of waste materials;

- utilize a mix of Energy Systems and subcontract personnel to ensure all S\&M and deactivation activities are conducted in the most cost-effective manner;

- utilize private sector resources and expertise in incentivised performance contracts to facilitate deactivation activities on time and within budget;

- develop a work breakdown schedule (WBS), identify deactivation activities and methods of accomplishment, and provide a detailed current facility list; and

- develop a Life Cycle Baseline and a 5-Year S\&M Plan, which will be updated annually. 


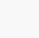




\section{PROJECT OBJECTIVES AND APPROACH}

\subsection{PROJECT OBJECTIVES}

The ultimate goal of HRFDP is to turn over stewardship and ownership of the high-risk ranking facilities to the EM-40/D\&D program quickly, safely, and economically. Before these facilities can be transferred to EM-40, each facility must be permanently deactivated and placed in a safe, stable, secure condition; the history and final status of the facility must be thoroughly documented; and a 5-year postdeactivation S\&M plan must be developed.

All programmatic operations at the facility must be terminated before the facility is a candidate for deactivation. An MOA between EM-60 and the previous owners must be drawn up to document that no future programmatic operations are planned. This MOA will require approval from the operations office and the appropriate headquarters program offices.

According to the draft EM-40 acceptance criteria, any immediate threats to human health, safety, and the environment must be eliminated by placing the facility in a safe, stable, and secure condition. Bulk quantities of special nuclear materials, reactor fuel, high-level waste, and Resource Conservation and Recovery Act (RCRA) hazardous wastes must be removed prior to transfer to EM-40, unless otherwise agreed. The buildings and systems at the facility must be structurally sound so as to permit deferred final decommissioning of the facility for 5 to 10 years after turnover. During this period, EM-60 will remain responsible for the facility until EM-40 is prepared for the transfer of responsibility. Exceptions to this requirement may be made in cases where EM-40 is prepared to support S\&M. In accordance with DOE Order 5400.1 (General Environmental Protection Program), the structures and monitoring systems of the deactivated facility must be in adequate physical condition to contain potential releases of residual radioactive contamination. The structures and security systems must also be in sufficiently good condition to preclude unauthorized entry to all structures of the facility.

The history of each facility must be documented before transfer to EM-40 so that EM-40 will be aware of the types of future potential problems that may arise. This history must enumerate all the known radionuclides and hazardous chemicals ever used or stored at the site. All processes and operations employed at the facility must be described. Any known chemical or radiological spills, inadvertent releases, and accidents must be noted.

The documentation on the final status of each facility must address all relevant systems and issues, including the water system, sewers, ventilation system, utilities, fire protection, and regulatory compliance. Survey records, S\&M requirements, procedures, and unplanned occurrence records must be provided to EM-40 at the time of transfer for any radiological/hazardous materials remaining at the site. Where possible, surveys must document the nature and extent of any contamination to soil, surface water, and groundwater. The compliance status of all regulatory commitments must be reported. Any plans or agreements to correct previously discovered violations must be included. Such regulatory commitments would include the Occupational Safety and Health Administration (OSHA); RCRA; the Comprehensive Environmental Response, Compensation, and Liability Act (CERCLA); the Toxic Substances Control Act (TSCA); the National Environmental Policy Act (NEPA); and others as may be applicable, including DOE Orders and state regulations.

Specific facility endpoint criteria have been established that identify those actions and activities that must be completed prior to the turnover of each facility to EM-40. These criteria have been included in Chap. 3 of this work plan. 


\subsubsection{Environment, Safety, and Health Objectives}

Objectives are to

- serve as a local and national model for the DOE-HQ EM-60 Program environment, safety, and health (ES\&H) protection awareness and preparedness;

- characterize the potential risks posed by HRFDP facilities sufficiently to design deactivation and S\&M plans that effectively protect ES\&H systems while simultaneously reducing S\&M costs and accomplishing deactivation as economically as possible;

- plan and implement deactivation activities to minimize worker, public, and ecological risk as well as reduce overall costs and risk liability;

- implement an S\&M program to place HRFDP facilities in a storage configuration that minimizes $S \& M$, worker, public, and environmental risk for the present and near term future while maintaining an adequate safety envelope for each facility;

- develop plans and establish systems to monitor potential releases and to mitigate and document unplanned releases associated with deactivation and S\&M activities; and

- seek opportunities to develop and apply innovative and creative technologies (e.g., remote and robotics systems) to further reduce potential worker exposure to hazards.

\subsubsection{Compliance Objectives}

Objectives are to

- Serve as a model project with respect to the identification of, and compliance with, requirements, orders, and guidelines applicable to EM-60 deactivation and S\&M activities;

- identify the pertinent DOE Orders and guidelines, state requirements, U.S. Environmental Protection Agency (EPA) requirements, and other federal requirements that are applicable to deactivation and S\&M plans and actions. Apply these drivers directly to the assessment of S\&M and deactivation activities to aid in determining a risk/benefit analysis;

- design project and quality assurance $(\mathrm{QA})$ plans to enable all deactivation activities to comply with all applicable and relevant requirements; and

- develop graded approaches to health and safety compliance strategies and deactivation activities appropriate for shutdown of EM-60 surplus facilities.

\subsubsection{EM-60/EM-40 Transition Objectives for Those Facilities Destined for D\&D}

Objectives are to

- Serve as a model EM-60 project with respect to a smooth, orderly, and cost-effective transition of facilities from EM-60 to EM-40;

- identify the minimum set of prioritized deactivation activities that must be completed for each facility for transition to EM-40;

- identify additional transition activities that could reduce life cycle costs using cost and risk decision criteria; and 
- establish and maintain a formal system for planning, estimating, scheduling, and accomplishing EM-60/EM-40 facility transition actions.

\subsubsection{Waste Management Objectives}

Objectives are to

- incorporate secondary waste stream minimization into deactivation and S\&M plans;

- implement deactivation alternatives that strive to maximize waste segregation and recycling opportunities while minimizing life cycle waste management and S\&M costs;

- provide a platform for developing and applying creative new systems, management techniques, and technologies for technically sound and cost efficient waste treatment, storage, and disposal and recycling where applicable;

- develop and implement project approaches and plans designed to minimize waste-handling and packaging requirements;

- develop estimates and projections regarding the nature and magnitude of wastes expected from deactivation and S\&M activities to support waste management program planning; and

- maximize acceptance of remaining HRFDP waste by private industry through planning or generating waste streams that meet applicable industry waste acceptance criteria.

\subsection{PROJECT APPROACH}

The basic mission of HRFDP is to place assigned facilities into a safe, stable, and deactivated state with the lowest possible S\&M cost while maintaining adequate safety envelopes. Technical requirements define the project's completion and the acceptable conditions for turnover to the D\&D Program. Concurrently, HRFDP will have to manage continuous uncertainty and perceived potential risk while maintaining all assigned facilities in a safe condition and ensuring timely transfer to EM-40.

The technical requirements specified here represent the best technical judgment of engineers, facility managers, and technicians experienced in past facility operations and those knowledgeable about the current conditions of the facilities.

\subsubsection{General Technical Requirements}

General technical requirements to be met by the project are those set forth in the draft DOE Policy Memorandum for Acceptance of Facilities for ER Program, issued March 15, 1991, by L. F. Duffy. HRFDP shall ensure that imminent hazards to personnel or the environment are controlled through partial closure, removal, isolation, mitigation, or stabilization. HRFDP shall also ensure that structures can be maintained in a safe condition, with removal of immediate threats to human health and safety or implementation of appropriate compensatory measures (barriers, access controls, administrative controls, etc.). Following deactivation, the facilities shall be classified as unoccupied facilities. As such, compliance with DOE Order 6430.1A, General Design Criteria (which establishes minimum design requirements for occupied facilities), is not required. The project shall ensure that access during the surveillance phase is not required at a greater frequency than necessary to maintain the unoccupied safe facility status. 


\subsubsection{Configuration Requirements}

The configuration of HRFDP facilities shall be modified and controlled sufficiently to ensure safety and regulatory compliance during project performance and postproject S\&M. As the minimum configuration control requirement, records shall be established and archived for essential systems for post-project S\&M and future D\&D planning. As a minimum, the following records should be established and maintained by the HRFDP team:

- a description of each facility and a summary of its history and past use;

- final radiological status surveys;

- logbook files, equipment operating procedures, S\&M requirements, procedures, records, drawings, photographs, etc., that reflect "as-left" configuration;

- zero energy-check records for electrical circuits that were de-energized;

- installed piping system and equipment blank records;

- facility hazards screening documents (HSDs) and related facility safety documentation;

- radiological posting in compliance with applicable requirements set forth in RPP-230 "Radiological Posting" and the DOE Radiological Control Manual;

- pending radiation occurrence reports, event fact sheets, unusual occurrence reports, and/or any other out-of-standard condition reports finalized and closed out;

- documentation demonstrating compliance with worker safety and health requirements;

- any required permits relating to the facility's current or anticipated use (activities shall not preclude subsequent closure options until permitting dictates final closure); and

- deactivation check sheets completed and approved by the responsible personnel performing the actual work, the overview organizations, and plant management.

\subsubsection{Hazardous and Radioactive Materials Removal/Stabilization Requirements}

Hazardous and radioactive materials shall be removed from the facilities or stabilized/fixed sufficiently to ensure long-term safety and regulatory compliance and enable subsequent successful transfer to D\&D. Materials shall be removed and/or stabilized sufficiently to ensure that the facilities comply with the ORNL Radiological Control Manual, as applicable, to a unoccupied facility after completion of deactivation. As a general guide, "as-left"contamination and radiation levels should be no greater than the levels encountered during normal operation and occupancy of the facilities.

To ensure long-term safety and regulatory compliance, the following requirements generally apply:

- Permanent radiation areas to be entered for surveillance shall be decontaminated or the surface contamination fixed or stabilized to preclude resuspension and/or migration of loose contamination. Temporary radiation areas inside and outside of buildings shall be eliminated. These operations will be examined in a cost/benefit analysis to define alternative approaches.

- Packaged radioactive and mixed waste with identified final disposition shall be removed and disposed of or recycled as appropriate.

- All hazardous materials shall be removed and disposed of or recycled as necessary according to 
appropriate regulatory guidelines and requirements. This goal will reduce corporate liability and maximize potential cost reductions.

- Loose or damaged (friable) asbestos in areas expected to be entered during surveillance shall be removed or stabilized. Each instance should be examined on a case-by-case basis to manage exposure risks.

- Tanks, vessels, and pipes shall be drained using installed equipment and features. Where possible, heels should not contain material classified as hazardous waste.

- Hazardous materials used for deactivation and cleanup work shall be collected and disposed of or recycled as appropriate.

- Emergency lighting and associated batteries from the facilities shall be removed and disposed of as appropriate.

To ensure minimum life cycle cost, the following general requirements apply:

- Surplus materials, furniture, equipment, supplies, and spare parts should be characterized, inventoried, labeled, segregated, and transferred to other facilities for use or disposed of as waste or recycled as appropriate.

- Reuse or recycling in lieu of disposal of waste materials will be maximized during deactivation.

- Existing system and equipment capabilities will be used for material removal/stabilization to the maximum extent possible.

- Operations and inventories that require implementation of technical safety requirements during the surveillance period will be eliminated (i.e., removing spent nuclear fuels).

\subsubsection{Surveillance and Maintenance Requirements}

Facility configuration shall be managed to ensure that $D \& D$ options are not foreclosed and that facility safety and environmental protection can be maintained until D\&D activities are completed.

To ensure safety and environmental protection during surveillance, the following requirements generally apply:

- Consistent with the ORNL plant safety bases, such as limiting conditions documents (LCDs), technical safety requirements, hazards screening documents (HSDs), etc., the operation of safety and utility system shall be reduced to the lowest extent possible while maintaining ventilation, alarms, and other capabilities necessary for a deactivated facility. Required vital safety systems and utility systems shall be fully functional and have operating procedures in place as necessary. To minimize points of ingress, doors to the facilities shall be locked from the inside except those required for entrance by surveillance crews. Surveillance and emergency crews will be assigned keys for access to secured facilities as necessary.

- Security systems and procedures shall be adequate to prevent any unauthorized entry to facilities. All facility entries and activities shall be logged.

- Liquid effluent sources from facilities, if any, shall be eliminated prior to the transfer to D\&D. Flow routes to disposal sites will be isolated. Isolation will be achieved by sealing or turning off valves at supply points and screening off accessible outlets of the discharge pipes for varmint control. 
- Facility penetrations (louvers, pipe openings, etc.) will be closed off where practical to prevent intrusions by birds and other animals.

- Systems that were opened to facilitate deactivation and could present a radiological and/or an industrial safety problem if left open shall be adequately closed off and locked.

- Known facility roof leaks and/or deteriorated roof panels should be repaired as necessary.

- Radiation space monitoring and continuous air monitoring systems shall be reduced to a level commensurate with the identified surveillance requirements and their regulatory drivers. As a general guide, "as-left" contamination and radiation levels in the facilities should be low enough that only portable or external telemetric monitoring equipment is required.

To achieve an unoccupied facility status, the following requirements generally apply:

- Ventilation and monitoring equipment shall be eliminated or consolidated, relocated, housed, operated, and/or maintained such that facility entry frequency does not compromise the unoccupied status.

- Fire protection systems shall be modified or eliminated, consistent with all codes and fire regulations, to both achieve and reflect the unoccupied status and to minimize system testing and maintenance.

- Electrical and water supply services to the process buildings shall be isolated where possible; electrical and water supply services in the surrounding yard areas shall be reduced where possible to meet minimum surveillance requirements.

- The building steam system shall be deactivated wherever practical. If not practical to deactivate the system, it shall be inspected and upgraded to ensure a 5-year operating life before being transferred to D\&D.

- When building, heating systems must remain in operation to protect facility equipment and/or systems from freezing; temperatures in the facilities will be maintained at the lowest temperatures consistent with protection of the facility.

\subsection{FACILITY DEACTIVATION PROCESS}

The process of deactivating facilities is illustrated in Fig. 2.1. The figure indicates the general sequence of the deactivation process; however, some steps (i.e., waste disposal) are performed in parallel with other steps or are continuous throughout the deactivation process. The exact deactivation sequence is actually determined on a facility- and activity-specific basis. 


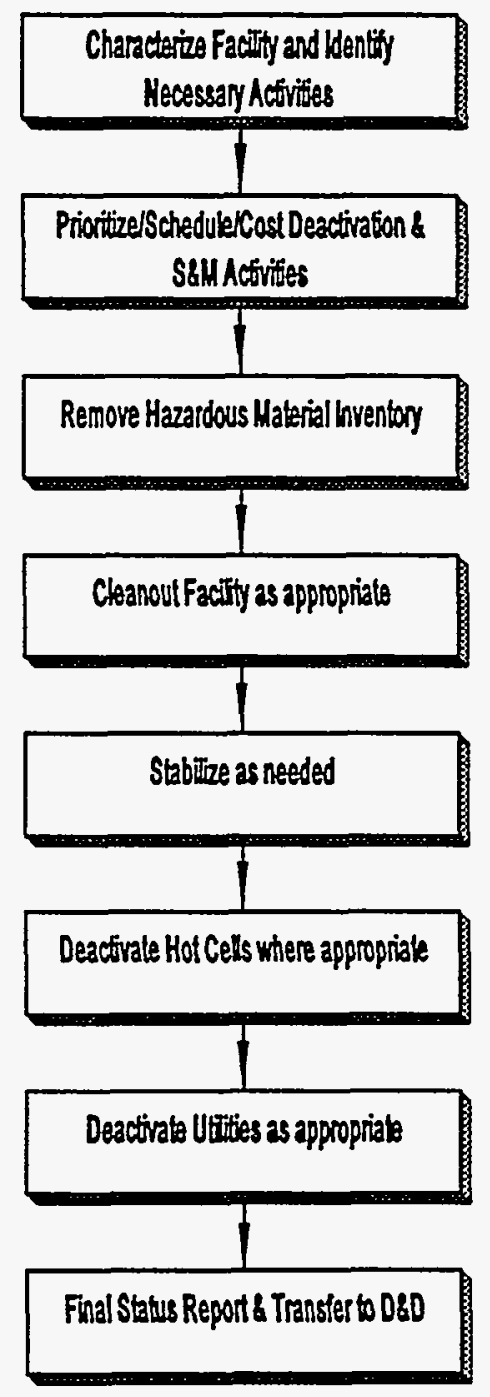

Fig. 2.1. High Ranking Facilities Deactivation Project-deactivation process for surplus facilities. 
The following lists the specific goals to be accomplished in completing each step shown in Fig. 2.1:

1. Characterize facility conditions.

- Update radiological surveys.

- Assess facility conditions.

- Inventory hazardous chemicals in facility.

- Inventory radioactive materials in facility.

- Baseline current $\mathbf{S} \& M$ activities.

This activity is required to assess and manage existing ES\&H risks associated with a facility and to baseline existing S\&M costs.

2. Prioritize deactivation activities (procedures).

- Prioritize/schedule/estimate costs for all activities.

- Evaluate activities for liability, cost reduction, and worker risk.

- Establish deactivation end-point criteria.

- Finalize evaluation utilizing life cycle cost reduction analysis.

Based on the information obtained in Step 1, activities will be identified that will simultaneously reduce ES\&H risks and S\&M costs. These will be prioritized according to risk reduction and cost savings.

3. Remove inventory.

- Remove radioactive materials.

- Remove hazardous chemicals, except those needed for decontamination tasks.

This step, which reduces the hazards classification of a facility and allows a reduction in facility safety documentation, is required to meet EM-40 acceptance criteria. It will also reduce the S\&M costs associated with ensuring adequate containment of the materials.

4. Clean out facility.

- Remove surplus equipment.

- Remove loose unanchored equipment from hot cells, hoods, and glove boxes.

- Remove abandoned equipment from operating areas.

- Characterize, package, and remove all wastes.

This step will salvage usable equipment and is a good housekeeping practice. Abandoned equipment such as old office furniture, storage cabinets, etc., will be removed. This also eliminates combustible materials from facilities which, in some cases, may reduce fire protection requirements. 


\section{Stabilize facility.}

- Remove transferrable contamination from secondary containment.

- Bond and label fixed contamination.

- Repair deficiencies in primary containment systems where necessary.

- Remove potential airborne contamination from hoods and glove boxes.

- Deactivate all services to hoods and glove boxes and seal drains.

- Repair roofs as necessary.

A structurally sound facility is required by the EM-40 facility acceptance criteria. Removal of contamination will reduce hazards to S\&M personnel, reduce background levels, ensuring longer life for seals and glove boxes, reduce the frequency of filter changes, and minimize the potential for a release to the environment. Since drains will be plugged, all sources of liquids must be eliminated. Services to hoods and glove boxes must be similarly eliminated.

6. Deactivate hot cells (where necessary).

- Perform initial cell decontamination.

- Terminate all fluid penetration into cells.

- Deactivate all electrical service to the cells.

- Plug all drains.

- Seal and lock all access ports.

Deactivation of hot cells will significantly decrease life cycle S\&M costs. This will minimize or eliminate the need for the use of monitrons and continuous air monitors from facilities. The service life of manipulator boot and in-cell filters will be extended. Plugging of all drains is required by the Federal Facility Agreement. With all drains plugged, it is essential that all possible pathways for introduction of liquids into cells be eliminated; thus, all penetrations and access ports must be sealed and/or collection devices and alarms be utilized.

7. Deactivate utilities in facilities.

- Deactivate all electrical circuits except those used for monitoring or required ventilation systems.

- Deactivate and drain all piping.

- Remove all unnecessary instrumentation.

These above steps eliminate utility costs and future maintenance of these systems.

8. Prepare Final Facility Status Report.

- Document facility history.

- Document "as-left" condition. 
- Develop procedures for postdeactivation $S \& M$ and for unplanned entries.

- Transfer facilities to EM-40.

\subsubsection{Deactivation Activities}

The following is a description of activities to complete deactivation and achieve a configuration requiring minimal $S \& M$. These activities are required to reduce facility $S \& M$ costs and/or mitigate ES\&H vulnerabilities and ensure regulatory compliance. The first several activities are generic in that the same basic activity will be repeated in several facilities. The specific deactivation activities that are planned for each facility, the methods by which these activities will be accomplished, and the endpoint criteria for each activity have been included in Chap. 3. In the following section, the term clean is relative to the process of removing debris followed by a wipe-down of surfaces to remove loose contamination. The term does not necessarily imply that protective clothing will or will not be necessary for entry or that facility entry should be controlled.

\subsubsection{Piping, utility, and alarm deactivation}

All water, air, steam (if practical), and gas piping will be disconnected at the supply header coming to the facility. All lines will be drained. All electrical service not essential to the basic S\&M requirements of the deactivated facility will be disconnected at the main breaker box. All radiation protection (RP) instruments and alarms will be removed. Remote air sampling capability will be installed wherever possible to minimize future entries into the facility.

\subsubsection{Fire protection}

Fire protection systems may be converted to dry systems if economically justifiable, or the buildings may be heated to maintain minimum temperatures above $40^{\circ} \mathrm{F}$ to avoid freezing of existing wet sprinkler systems. This is to be evaluated on a facility-specific basis.

\subsubsection{Final facility status report}

A final report will be prepared that will document the history of the building and the physical and radiological condition of the facilities, provide as-is drawings of essential facility support systems where available, and provide correctly defined S\&M requirements and procedures. 


\section{FACILITY-SPECIFIC ACTIVITIES AND ENDPOINT CRITERIA}

The purpose of the deactivation activities listed in this section is to place the facilities in a safe, stable condition requiring a minimum amount of S\&M. The endpoint of these activities were chosen to obtain an optimum balance between the S\&M reductions and safety increases, and the cost incurred in performing the activities. All the deactivation activities presented in this section are subject to change based on funding, their abilities to reduce S\&M costs and risks, and their abilities to meet EM-40 acceptance criteria. Also, the methods of accomplishment and endpoint criteria are subject to change as better and lower-cost ways are found to perform the tasks. These are not engineered methods performed in an alternatives analysis. The tasks will promptly (depending on funding) be prioritized and provide conceptual estimates and start and end dates for all activities.

\subsection{TOWER SHIELDING FACILITY (7700)}

The key end points for the deactivation of the TSF are the removal of the spent reactor fuel and radioactive sources, permitting achievement of significant reductions in S\&M costs, removal of sodium and other hazardous substances, and recycling of scrap metal. Levels of radioactive contamination inside the TSF buildings are low compared with the other high-risk ranking facilities, and little work will be required to deactivate them once the inventories have been removed. Nevertheless, many other activities are necessary to reduce overall risk and ensure and facilitate acceptance by EM-40.

\subsubsection{Building 7700 Tower Shielding Facility}

\subsubsection{Characterize Tower Shielding Facility}

A competent characterization of the facility is required to update radiological surveys, completely assess conditions within the facility, and develop a complete inventory of hazardous and chemical materials within the facility and on the site.

Method of Accomplishment: Develop a characterization plan and perform radiological surveys both within the facility buildings and around the site. Map and regulate the facility to reflect the information obtained in the updated characterization study.

End Point: The end point will be when the facility and ancillaries are fully characterized and documented in a characterization report.

\subsubsection{Salvage demineralized water tanks}

After the reactor fuel is removed and the coolant circulation system shut down, the tanks serve no useful purpose. This activity cannot be performed prior to fuel removal. While the tanks remain at the TSF site, they must be periodically monitored to verify that no one is using the tanks for unauthorized disposal of hazardous materials. Removing the tanks from the site eliminates this surveillance requirement and consequently reduces S\&M costs.

Method of Accomplishment: An Office of Radiation Protection representative or a qualified subcontractor will conduct a smear survey on the tanks to verify that they are clean. A metal recycling subcontractor will remove the tanks to its off-site recycling facility. The subcontractor will be 
responsible for providing the trucks, cranes, jacks, and any other equipment and/or personnel required to remove the tanks from the site.

End Point: This task will be completed when the two demineralized water tanks have been removed from the site and the subcontractor certifies the steel and any residual contents have been recycled and/or disposed of according to any and all existing regulations and DOE Orders.

\subsubsection{Install north area institutional controls}

An outdoor area north of the towers, near Building 7720, contains some partially buried, activated concrete blocks. More radioactive items may be also be below the surface in this area. This raises concerns because the area is located outside the 600 -ft perimeter fence, in an area that the public has access to during scheduled deer hunts. Although the area is posted as a radiological area, it is possible that hunters could inadvertently enter the area. There are no documented cases of this inadvertent entry occurring, but such encroachments would likely go unreported. Two approaches can be taken to prevent such incursions. Either the activated material can be removed from this area and placed on the TSF pad within the 600 - $\mathrm{ft}$ perimeter fence, or a new fence can be constructed around this area.

Method of Accomplishment: If the activated concrete blocks visible are the only contaminated/activated material in the area, a forklift driven up the access road will be used to transport the blocks to an appropriate area within the fence. The blocks may be placed along with other activated concrete blocks on the TSF pad or in the boneyard. If more contaminated/activated material is found underground, Plant and Equipment (P\&E) Division personnel or a competent subcontractor will construct a fence around the area using standard techniques. The gate to this fence will be securely locked, and radiation waming signs will be posted as appropriate.

End Point: This task will be completed when all activated items in this area are behind an institutional barrier.

\subsubsection{Remove fuel lune plates from silo}

The reactor fuel lune plates, which are odd, annular-shaped fuel elements, contain weapons-grade uranium. Removing them from the site will alleviate safeguards and security concerns and significantly reduce S\&M costs.

Method of Accomplishment: This action will be done in conjunction with the removal of the reactor fuel loaded in the TSR-II core. See Sect. 3.1.2.1.

End Point: This task will be completed when the fuel lune plates have been removed from the site and sent to the Savannah River Site (SRS) or other facility as designated by DOE and when certification is received, accepting responsibility for the materials.

\subsubsection{Remove outdoor sodium shields}

Sodium is contained in the four large shielding blocks sitting on the TSF pad. One of these shields contains clean sodium, while the other three contain activated sodium. The sodium is a potential RCRA and safety issue and must be removed before the facility can be transferred to EM-40. If the shielding blocks developed leaks, the sodium would also represent a fire hazard. 
Method of Accomplishment: A qualified subcontractor will remove the sodium from the shields, oxidize it, and dispose of the $\mathrm{NaOH}$ off site. The outdoor sodium shields are too large to be loaded onto trucks, so the sodium must be removed from the shields and repackaged in appropriate containers at the TSF site in accordance with the U.S. Department of Transportation (DOT) requirements of 49 CFR 172. This can be accomplished by melting the sodium and draining the shields into smaller tanks under a controlled, dry atmosphere. The subcontractor will be responsible for developing a method for melting and draining the sodium out of the large shielding blocks. The subcontractor will also be responsible for providing the trucks, cranes, and any other equipment and/or personnel required to remove the material from the site. This activity should be done in conjunction with the removal of the additional sodium shields from Building 7708.

End Point: This task will be completed when the sodium in the outdoor shielding blocks has been removed from the site and the subcontractor certifies the sodium has been recycled and/or disposed of according to any and all existing laws and DOE Orders. The empty casks will remain at the TSF site pending eventual transfer to EM-40.

\subsubsection{Remove outdoor lithium hydride shields $(\mathrm{LiH})$}

The LiH/uranium ellipsoid shield stored south of the TSF pad should be removed and disposed of. $\mathrm{LiH}$ is a potential RCRA and safety issue and must be removed before the facility can be transferred to EM-40. If the shield were to leak, the material could easily become a fire hazard.

Method of Accomplishment: A qualified subcontractor will remove the shield, separate the depleted uranium and $\mathrm{LiH}$, oxidize the $\mathrm{LiH}$, and dispose of the $\mathrm{LiH}$ and depleted uranium off site. It is the responsibility of the subcontractor to develop a process to safely extract the uranium and oxidize the $\mathrm{LiH}$ in accordance with all applicable laws and regulations. The subcontractor will be also responsible for providing the trucks, cranes, and any other equipment and/or personnel required to remove the material off site and transport according to all DOT regulations. This task should be accomplished in conjunction with the removal of the additional $\mathrm{LiH}$ shields in Building 7708.

End Point: This task will be completed when the outdoor ellipsoid LiH/U shield has been removed from the site and the subcontractor certifies the $\mathrm{LiH}$, uranium, and the outer can have been recycled and/or disposed of in accordance with any and all existing laws and DOE Orders.

\subsubsection{Remove copper slab}

The copper slabs stored on the south side of the perimeter road near Building 7708 should be removed and disposed of.

Method of Accomplishment: An Office of Radiation Protection representative or a qualified subcontractor will conduct surveys of the slabs to determine the extent of contamination or activation, if any. A metal recycling subcontractor will be sought to buy clean material, or material containing only small amounts of surface contamination that can be easily washed off. A qualified subcontractor will remove and dispose off site any heavily activated material or material with no economic value. The subcontractor will be responsible for providing the trucks, cranes, and any other equipment and/or personnel required to remove the material off site. 
End Point: This task will be completed when the copper slabs are removed from the site and the subcontractor certifies the copper has been recycled and/or disposed of according to any and all existing laws and DOE Orders.

\subsubsection{Remove outdoor lead}

The lead slabs stored on the south side of the perimeter road near Building 7708 should be removed and disposed of. This material must be removed before the facility can be transferred to EM-40.

Method of Accomplishment: An Office of Radiation Protection representative or a qualified subcontractor will conduct surveys of the slabs to determine the extent of contamination or activation, if any. A metal recycling subcontractor will be sought to buy clean material, or material containing only small amounts of surface contamination that can be easily washed off. A qualified subcontractor will remove and dispose off site any heavily activated or contaminated material or material with no economic value. The subcontractor will be responsible for providing the trucks, cranes, and any other equipment and/or personnel required to remove the material off site.

End Point: This task will be completed when the lead slabs are removed from the site and the subcontractor certifies the lead has been recycled and/or disposed of according to any and all existing laws and DOE Orders.

\subsubsection{Remove hevimet slab}

Remove and dispose of the hevimet (an alloy of predominantly tungsten) slab stored on the south side of the perimeter road near Building 7708. This material must be removed before the facility can be transferred to EM-40.

Method of Accomplishment: An Office of Radiation Protection representative or a qualified subcontractor will conduct surveys of the slab to determine the extent of contamination or activation, if any. A metal recycling subcontractor will be sought to buy clean portions of the slab, or portions containing only small amounts of surface contamination that can be easily washed off. A qualified subcontractor will remove and dispose off site any heavily activated material or material with no economic value. The subcontractor will be responsible for providing the trucks, cranes, and any other equipment and/or personnel required to remove the material off site.

End Point: This task will be completed when the hevimet slab is removed from the site and the subcontractor certifies the hevimet has been recycled and/or disposed of according to any and all existing laws and DOE Orders.

\subsubsection{Remove bismuth slab}

Remove and dispose of the bismuth slabs stored on the south sicle of the perimeter road near Building 7708. This material must be removed before the facility can be transferred to EM-40.

Method of Accomplishment: An Office of Radiation Protection representative or a qualified subcontractor will conduct a survey of the slab to determine the extent of contamination or activation, if any. A metal recycling subcontractor will be sought to buy clean material, or material containing only small amounts of surface contamination that can be easily washed off. A qualified subcontractor will remove and dispose off site any heavily activated material or material with no economic value. The 
subcontractor will be responsible for providing the trucks, cranes, and any other equipment and/or personnel required to remove the material off site.

End Point: This task will be completed when the bismuth slabs are removed from the site and the subcontractor certifies the bismuth has been recycled and/or disposed of according to any and all existing laws and DOE Orders.

\subsubsection{Remove boron carbide shields}

Remove and dispose of the boron carbide shields stored on the south side of the perimeter road near Building 7708. This material must be removed before the facility can be transferred to EM-40.

Method of Accomplishment: An Office of Radiation Protection representative or a qualified subcontractor will conduct surveys of the shields to determine the extent of contamination or activation, if any. A recycling subcontractor will be sought to buy clean material, or material containing only small amounts of surface contamination that can be easily washed off. A qualified subcontractor will remove and dispose off site any heavily activated material or material with no economic value. The subcontractor will be responsible for providing the trucks, cranes, and any other equipment and/or personnel required to remove the material off site.

End Point: This task will be completed when the boron carbide shields are removed from the site and the subcontractor certifies the boron carbide has been recycled and/or disposed of according to any and all existing laws and DOE Orders.

\subsubsection{Remove boral sheets}

Remove and dispose of the boral sheets stored on the south side of the perimeter road near Building 7708. This material must be removed before the facility can be transferred to EM-40.

Method of Accomplishment: An Office of Radiation Protection representative or a qualified subcontractor will conduct surveys of the sheets to determine the extent of contamination or activation, if any. A recycling subcontractor will be sought to buy clean material, or material containing only small amounts of surface contamination that can be easily washed off. A qualified subcontractor will remove and dispose off site any heavily activated material or material with no economic value. The subcontractor will be responsible for providing the trucks, cranes, and any other equipment and/or personnel required to remove the material off site.

End Point: This task will be completed when the boral sheets are removed from the site and the subcontractor certifies the boral sheets have been recycled and/or disposed of according to any and all existing laws and DOE Orders.

\subsubsection{Remove zirconium slab}

Remove and dispose of the zirconium slab stored on the south side of the perimeter road near Building 7708. This material must be removed before the facility can be transferred to EM-40.

Method of Accomplishment: An Office of Radiation Protection representative or a qualified subcontractor will conduct surveys of the slab to determine if it is contaminated or activated. If it is clean or contains only surface contamination that can be easily washed off, the material will be green-tagged and sold on the commercial market. If the material is activated, a qualified subcontractor will remove it 
for off-site disposal. The subcontractor will be responsible for providing the trucks, cranes, and any other equipment and/or personnel required to remove the material off site.

End Point: This task will be completed when the zirconium slab is removed from the site and the subcontractor certifies the zirconium has been recycled and/or disposed of according to any and all existing laws and DOE Orders.

\subsubsection{Remove thorium dioxide shields}

Remove and dispose of the thorium dioxide shields stored outdoors near Building 7708. Hazardous and radiological materials must be removed from the facility before transfer to EM-40.

Method of Accomplishment: A set of disposition alternatives will be compiled. These options will be evaluated and assessed. The optimum solution identified will be implemented.

End Point: This task will be completed when the $\mathrm{ThO}_{2}$ shields have been removed from the site and the subcontractor certifies the thorium dioxide has been recycled and/or disposed of according to any and all existing laws and DOE Orders.

\subsubsection{Remove cadmium shields}

Remove and dispose of the cadmium stored in shields outdoors near Building 7708.

This material must be removed before the facility can be transferred to EM-40.

Method of Accomplishment: An Office of Radiation Protection representative or a qualified subcontractor will conduct surveys of the shields to determine the extent of contamination or activation, if any. A recycling subcontractor will be sought to buy clean material, or material containing only small amounts of surface contamination that can be easily washed off. A qualified subcontractor will remove and dispose off site any heavily activated material or material with no economic value. The subcontractor will be responsible for providing the trucks, cranes, and any other equipment and/or personnel required to remove the material off site.

End Point: This task will be completed when the cadmium shields are removed from the site and the subcontractor certifies the cadmium has been recycled and/or disposed of according to any and all existing laws and DOE Orders.

\subsubsection{Remove main hoist towers}

Dismantle the main hoist towers. Salvage clean portions of the towers as scrap metal, and dispose of the activated portions as solid low-level waste (must be done after reactor fuel removal). Maintaining the towers would require repainting every five years at a cost of more than $\$ 300 \mathrm{~K}$. Dismantling them removes this S\&M requirement reducing costs dramatically.

Method of Accomplishment: An erection subcontractor will be hired to dismantle the towers. After the towers have been dismantled, an Office of Radiation Protection representative or a qualified subcontractor will conduct a radiological survey on the tower components. Inactivated portions will be cut off and taken by a metal recycling subcontractor for off-site recycling. A qualified subcontractor will remove the activated portions of the tower components and dispose of the materials off site. The 
subcontractor will be responsible for providing the trucks, cranes, and any other equipment and/or personnel required to remove the material off site.

End Point: This activity will be concluded when all of the tower components have been moved off site and the subcontractor certifies that the steel has been recycled or disposed of in a manner in accordance with any and all existing laws and DOE Orders.

\subsubsection{Remove tank mover}

Remove the tank remover and salvage for scrap metal.

Method of Accomplishment: A Health Physics representative or a qualified subcontractor will conduct a radiological survey on the tank remover. If it is clean, the steel will be recycled. If the tank remover is activated, it will be disposed of as waste. A qualified subcontractor will remove the tank remover and recycle or dispose of the material off site. The subcontractor will be responsible for providing the trucks, cranes, and any other equipment and/or personnel required to remove the tank remover off site.

End Point: This task will be completed when the tank remover has been removed from the TSF site and the subcontractor has certified that the steel and other components of the tank remover have been recycled or disposed in accordance with any and all existing laws and DOE Orders.

\subsubsection{Remove reactor fuel loaded in TSR-II reactor core}

The TSR-II reactor core is located inside the big beam shield. See Sect. 3.1.2.1.

\subsubsection{Remove instrumentation towers}

Dismantle the instrumentation towers, conduct a radiological survey of the dismantled tower components, and remove the components for recycle or disposal. The underground anchors supporting similar towers have corroded, causing the towers to fall. To prevent this potential accident from occurring at TSF, causing injury or death to site personnel, these towers should be removed.

Method of Accomplishment: An erection subcontractor will be hired to dismantle the towers. The erection subcontractor will erect scaffolding around each tower and begin cutting and removing sections of the towers, starting from the top. The erection subcontractor will be responsible for supplying cranes, scaffolding equipment, and any other equipment or personnel required to complete this task. After the tower has been dismantled, a Health Physics representative or a qualified subcontractor will conduct a radiological survey of the tower components. Clean portions are to be green-tagged. A metal recycling subcontractor will remove the clean portions to their off-site recycling facility. Activated portions (if any) must be compacted and disposed of as solid low-level waste. A subcontractor will remove these portions and dispose of them in accordance with all existing laws and relevant DOE Orders. The subcontractor will be responsible for providing the trucks, cranes, and any other equipment and/or personnel required to remove the material off site.

End Point: This activity will be completed when the dismantled components have been removed from the site and the subcontractor certifies that the steel has been recycled or disposed in accordance with any and all existing laws and DOE Orders. 


\subsubsection{Salvage tank 7700C}

Green-tag the 7700C tank and salvage the steel as scrap. This tank no longer serves a useful purpose. While the tank remains at the TSF site, it must be periodically monitored to verify that no one is using it for unauthorized disposal of hazardous materials. Removing the tank from the site eliminates this surveillance requirement.

Method of Accomplishment: An Office of Radiation Protection General Environmental Protection Program representative or a qualified subcontractor will survey it to verify that the tank is clean. The tank can be lifted onto a truck with a crane without requiring any on-site dismantlement. A metal recycling subcontractor will take the tank to its off-site facility. The subcontractor will be responsible for providing the truck, crane, and any other equipment and/or personnel required to remove the tank off site.

End Point: This task will be completed when this tank is off the site and the subcontractor certifies that the steel has been recycled or disposed in accordance with any and all existing laws and DOE Orders.

\subsubsection{Final facility status report}

Prepare the final facility status report as documented in Sect. 2.3.1.3.

Method of Accomplishment: Document all characterization and survey maps, and redline facility drawings to reflect all system and facility changes.

End Point: This task will be completed when the final facility status report has been issued and been approved by DOE Headquarters.

\subsubsection{Building 7700A, Big Beam Shield (Reactor Facility)}

\subsubsection{Remove reactor fuel}

Remove the reactor fuel loaded in the TSR-II core. It is assumed by the Research Reactor Division (RRD) that the reactor fuel will be sent to the Savannah River Site, a new dry storage site at Oak Ridge, or to the Bulk Shielding Facility (BSF) pool for interim storage.

Removing the fuel will result in a dramatic reduction in risk, liability, and S\&M costs. After the reactor fuel is removed from the site, the coolant circulation system can be safely shut down. This will eliminate the need for demineralized water, demineralizer resin, electrical power for the pumps and filter presses, and maintenance to keep the system operating. The reactor fuel also contains weapons-grade uranium, so removing the fuel will alleviate safeguards and security concerns. Additionally, the facility manager will not be required to maintain Senior Reactor Operator (SRO) status.

Method of Accomplishment: A list of disposition options for the fuel will be identified. These options will include leaving the fuel in place until the Savannah River Site or other spent fuel repository is able to accept the material, building a dry storage facility at ORNL, and/or moving the fuel to BSF for interim storage. The merits of each option will be studied, assessed, and evaluated. After the optimum plan is selected, a fuel removal plan will be prepared and implemented. 
Before the fuel can be removed from the reactor, the current broken hoist will be repaired and certified and the TSF handling pool cleaned. After the TSF fuel basket has been approved by NRC, it will be fabricated by GE and sent to ORNL. The baskets and the GE-2000 shipping cask will arrive at the TSF site. The TSF handling pool will be filled with demineralized water. The tower hoists will lift the reactor out of the big beam shield and place it in the handling pool. While in the pool, the fuel elements will be dismantied and loaded into the baskets. The baskets will be placed in the GE-2000 shipping cask and covered with the overpack. The shipping cask and fuel will then be transported in a safe, secure trailer (SST) to the location chosen by DOE for permanent or interim storage of the fuel.

End Point: This task will be completed when the reactor fuel has safely arrived at the SRS or other site designated by DOE for final disposition.

\subsubsection{Deactivate unnecessary services}

Deactivate all unnecessary piping, utilities, and alarms as indicated in Sect. 2.3.1.1. Evaluate and document all facility safety systems. Deactivate all nonessential systems. It is anticipated that all systems to this structure can be deactivated (must be done after reactor fuel removal).

\subsubsection{Final facility status report}

Prepare the final facility status report as documented in Sect. 2.3.1.3.

Since this is an ancillary facility, status will be included in the final facility status report of the primary facility (TSF).

\subsubsection{Building 7700B Outside Source Storage Area (OSSA)}

\subsubsection{Remove radioactive sources}

Remove and dispose of, as appropriate, the radioactive sources stored in OSSA. Removing the sources would eliminate the need to monitor the area and is required under EM-40 acceptance criteria.

Method of Accomplishment: Possible disposal locations will be identified and assessed, and the optimum location chosen. The sources are currently stored in a retrievable form. The sources will be removed in the manner specified by the relevant procedures and then shipped to the chosen disposal site in accordance with all applicable laws and DOT regulations. This activity should be done in conjunction with the removal of the radioactive sources stored in the 7702 Control House and the BSF pool.

End Point: Completion of this activity will occur when the sources are removed from the TSF site and disposed of in accordance with any and all existing laws and relevant DOE Orders.

\subsubsection{Final facility status report}

Prepare the final facility status report as documented in Sect. 2.3.1.3.

Since this is an ancillary facility, status will be included in the final facility status report of the primary facility (TSF). 


\subsubsection{Tower Shielding Civil Defense Facility (Bunker)}

\subsubsection{Move activated blocks}

Move the activated reinforced concrete blocks from the bunker's entrance inside the TSF $600-\mathrm{ft}$ perimeter fence. During scheduled deer hunts, this area is open to the public. The chain and radiation signs currently posted around the area are not a sufficient barrier to preclude unauthorized access to the area.

Method of Accomplishment: A fork lift will be driven to the Civil Defense Facility along the gravel access road. The fork lift will carry each activated block to an appropriate location within the 600-ft perimeter fence. The blocks may be placed along with other activated blocks on the TSF pad, or be placed in the boneyard.

End Point: This activity will be completed when the concrete blocks are safely stored within the 600-ft perimeter fence.

\subsubsection{Final facility status report}

Prepare the final facility status report as documented in Sect. 2.3.1.3. Since this is an ancillary facility, status will be included in the final facility status report of the primary facility (TSF).

\subsubsection{Building 7701 Tower Shielding Handling Pool}

\subsubsection{Prepare pool for fuel transfer}

Lift concrete slab covering pool, clean pool, and fill with demineralized water (should be done just before reactor fuel removal). During the fuel removal process, the reactor core will be lifted and placed in the pool. The water in the pool will provide shielding while the reactor fuel is being removed from the reactor and moved into the shipping cask.

Method of Accomplishment: A portable crane will be used to remove the concrete slab covering the pool. The pool will not be decontaminated at this point but only rinsed to remove gross levels of dirt and debris. Water from this process will be drained, loaded aboard trucks, and put into the ORNL or Y-12 Plant liquid low-level waste (LLLW) treatment system. Instrumentation will be upgraded, as necessary. Demineralized water from Building 3004 will be supplied by a tank truck. The pumps and filters in Building 7716 will be employed to maintain the quality of the water, as necessary.

End Point: This task will be completed when the pool is cleaned, filled, and ready to receive the reactor core.

\subsubsection{Clean and cover pool}

Drain and cover the pool with the concrete slab (must be done after reactor fuel removal). This is necessary to put the pool in a stable, safe, and secure shutdown condition.

Method of Accomplishment: The water in the pool will be drained into a tank. The tank will be loaded aboard a truck and transported off the TSF site and put into the ORNL or Y-12 Plant LLLW system for the appropriate treatment. After evaporation of residual water, a portable crane will cover the pool with a concrete pad. 
End Point: This task will be finished when the pool has been drained, painted, and covered.

\subsubsection{Final facility status report}

Prepare the final facility status report as documented in Sect. 2.3.1.3. Since this is an ancillary facility, status will be included in the final facility status report of the primary facility (TSF).

\subsubsection{Building 7702 Control House}

\subsubsection{Remove radioactive sources}

Remove radioactive calibration sources from the safe in the hallway between Buildings 7702 and 7704. Radiological hazards must be removed prior to transfer of the facility to EM-40.

Method of Accomplishment: Possible disposal locations will be identified and assessed, and the optimum location chosen. The sources are currently stored in a retrievable form. The sources will be removed in the manner specified by the relevant procedures and then shipped to the chosen disposal site in accordance with all applicable laws and DOT regulations. This activity should be done in conjunction with the removal of the radioactive sources stored in the 7700B OSSA and the BSF pool.

End Point: Completion of this activity will occur when the sources are removed from the TSF site and certified disposed of or stored in accordance with any and all existing laws and relevant DOE Orders.

\subsubsection{Remove lithium}

Remove the lithium metal stored in the building. The lithium must be removed before the facility can be turned over to EM-40.

Method of Accomplishment: The small quantity $(-1.5 \mathrm{~kg})$ of this material does not justify the work required to make arrangements for disposing of the material off site. The material will be transported to an identified building in the main ORNL plant area for temporary storage until ORNL personnel have a use for the material.

End Point: This task will be completed when the material has been removed from the TSF site and placed in interim storage.

\subsubsection{Deactivate unnecessary services}

Deactivate all unnecessary piping, utilities, and alarms as indicated in Sect. 2.3.1.1 (must be done after reactor fuel removal). It is anticipated that all services to this building may be terminated. Evaluate and document all facility safety systems. Deactivate all nonessential systems (must be done after reactor fuel removal).

\subsubsection{Fire protection}

No upgrades to the fire protection system are planned. After the facility has been deactivated, the economic value of the building will be too low to justify the expense of maintaining a fire prevention system. The existing sprinkler system will be deactivated. 


\subsubsection{Final facility status report}

Prepare the final facility status report as documented in Sect. 2.3.1.3. Since this is an ancillary facility, status will be included in the final facility status report of the primary facility (TSF).

\subsubsection{Building 7703 Hoist House}

\subsubsection{Repair hoist}

Repair the broken hoist (must be done before fuel removal). This hoist located at TSF and utilized to remove the reactor/storage casts will be needed to support the fuel removal process.

Method of Accomplishment: P\&E Division will supply mechanics and any material and/or equipment necessary to repair and certify the hoist.

End Point: This activity will be concluded when the hoist is functioning sufficiently to meet the performance criteria established in the TSF Operating Manual.

\subsubsection{Salvage hoists}

After the reactor fuel has been removed from the reactor, the hoists will serve no further purpose. Recycling the metal will allow the metal to be used for useful purposes rather than slowly deteriorating as the facility awaits eventual D\&D.

Method of Accomplishment: The hoisting cables will be disconnected from the towers. All electrical power sources to the hoists will then be disconnected. Any motor oil remaining in the hoists will be drained and added to the other motor oil being stored in the building, in compliance with all applicable current regulations and policies. A metal recycling contractor will remove the hoists for recycling. The subcontractor will be responsible for providing the trucks, cranes, and any other equipment and/or personnel required to remove the hoists from the site.

End Point: This activity will be completed when the hoists are removed from the site and the subcontractor has certified that the metal has been recycled in accordance with any and all existing laws and DOE Orders.

\subsubsection{Remove motor oil}

Remove used motor oil stored in Building 7703 (should be done after the hoists have been retired). The motor oil must be removed before the facility can be turned over to EM-40.

Method of Accomplishment: The oil will be packaged in the appropriate drums for transport. The ORNL Waste Management Division will collect the motor oil and deliver it to the ORNL Petroleum Recycling Group.

End Point: This task will be completed when the motor oil has been removed from the TSF site, and the Waste Management Division has certified that the oil has been recycled or disposed of in accordance with any and all existing laws and relevant DOE Orders. 


\subsubsection{Remove pesticides}

Remove pesticides stored in Building 7703. The wasp spray must be removed before the facility can be transferred to $E M-40$.

Method of Accomplishment: The cans of wasp spray will be loaded onto a truck and moved to a storage site in the ORNL main plant area. No additional packaging requirements are anticipated for transport. From there, it will be distributed where needed.

End Point: This task will be concluded when the pesticides have been moved to a storage building in the ORNL main plant area.

\subsubsection{Deactivate unnecessary services}

Deactivate all unnecessary piping, utilities, and alarms as indicated in Sect. 2.3.1.1 (must be done after reactor fivel removal). Evaluate and document all facility safety systems. Deactivate all nonessential systems (must be done after reactor fuel removal). It is anticipated that all services to this building may be terminated.

\subsubsection{Fire protection}

No upgrades to the fire protection system are planned. After the facility has been deactivated, the economic value of the building will be too low to justify the expense of maintaining a fire prevention system. The existing sprinkler system will be deactivated.

\subsubsection{Final facility status report}

Prepare the final facility status report as documented in Sect. 2.3.1.3. Since this is an ancillary facility, status will be included in the final facility status report of the primary facility (TSF).

\subsubsection{Building 7704 Control House 2}

\subsubsection{Remove lead bricks}

Remove and dispose of $5,700 \mathrm{lbs}$ of lead bricks stored in the building. The lead must be removed before the facility can be transferred to EM-40.

Method of Accomplishment: The Office of Radiation Protection or a qualified subcontractor will conduct surveys on a statistically required representative sample of the bricks. If they are found to be clean, or possess only surface contamination that can be easily washed off, the bricks will be sold on the commercial market. If the contamination/activation is more extensive, a qualified subcontractor will remove and dispose of the lead. The subcontractor will be responsible for providing the trucks, cranes, and any other equipment and/or personnel required to remove the material off site. This activity should be done, if possible, in conjunction with the removal of the outdoor lead slabs stored at TSF.

End Point: Conclusion of this activity will occur when the lead bricks have been removed from the TSF site and the subcontractor certifies that the lead has been recycled or disposed of in accordance with all existing laws and DOE Orders. 


\subsubsection{Deactivate unnecessary services}

Deactivate all umnecessary piping, utilities, and alarms as indicated in Sect. 2.3.1.1 (must be done after reactor fuel removal). Evaluate and document all facility safety systems. Deactivate all nonessential systems. It is anticipated that all services to this building may be terminated.

\subsubsection{Fire protection}

After the building has been deactivated, the economic value of the facility will be too low to justify the expense of maintaining a fire prevention system. The existing sprinkler system will be deactivated.

\subsubsection{Final facility status report}

Prepare the final facility status report as documented in Sect. 2.3.1.3. Since this is an ancillary facility, status will be included in the final facility status report of the primary facility (TSF).

\subsubsection{Building 7705 Pumphouse}

\subsubsection{Salvage clean metal items}

Green-tag and salvage as scrap any uncontaminated metal equipment (must be done after reactor fuel removal). The pumps will no longer be needed after the reactor fuel removal. Recycling will allow the metal to be used for other useful purposes.

Method of Accomplishment: The Office of Radiation Protection or a qualified subcontractor will conduct radiological surveys on the pumps to determine if they are contaminated. A metal recycling contractor will remove the material for recycling if it is found to be clean. The subcontractor will be responsible for providing the trucks, cranes, and any other equipment and/or personnel required to remove the material off site.

End Point: This task will be completed when the pumps have been removed from the TSF site or when the pumps have been found to be contaminated, in which case they will be left in place.

\subsubsection{Remove demineralizer resin}

Remove resin from the demineralizer and dispose of as low level radioactive waste (must be done after reactor fuel removal). After the water in the coolant circulation system is cut off, the resin will dry out. The dried resin powder could become a potential source of airborne transferrable contamination.

Method of Accomplishment: All lines bringing water to and from the demineralizer columns will be capped. After allowing residual water in the columns to drain, the columns will be placed, intact, into shipping drums, and removed from the building. The ORNL Waste Management Division will collect and dispose of the drums in accordance with all applicable laws and DOE Orders.

End Point: This activity will be completed when the demineralizing columns have been removed from the TSF site and the Waste Management Division certifies that they have been disposed of or stored in accordance with any and all existing laws and DOE Orders. 


\subsubsection{Deactivate unnecessary services}

Deactivate all unnecessary piping, utilities, and alarms as indicated in Sect. 2.3.1.1 (must be done after reactor fuel removal). Evaluate and document all facility safety systems. Deactivate all non-essential systems. It is anticipated that all services to this building may be terminated.

\subsubsection{Fire protection}

No upgrades to the fire protection system are planned. Building 7705 does not have a sprinkler system. The economic value of the building is too low to justify the installation of a sprinkler system.

\subsubsection{Final facility status report}

Prepare the final facility status report as documented in Sect. 2.3.1.3. Since this is an ancillary facility, status will be included in the final facility status report of the primary facility (TSF).

\subsubsection{Building 7706 Cooler}

\subsubsection{Deactivate unnecessary services}

Deactivate all unnecessary piping, utilities, and alarms as indicated in Sect. 2.3.1.1 (must be done after reactor fuel removal). Evaluate and document all facility safety systems. Deactivate all nonessential systems. It is anticipated that all services to this building may be terminated.

\subsubsection{Fire protection}

No upgrades to the fire protection system are planned. Building 7706 does not have a sprinkler system. The economic value of the building is too low to justify the installation of a sprinkler system.

\subsubsection{Final facility status report}

Prepare the final facility status report as documented in Sect. 2.3.1.3. Since this is an ancillary facility, status will be included in the final facility status report of the primary facility (TSF).

\subsubsection{Building 7707 Battery House}

\subsubsection{Remove batteries}

Remove and dispose of the lead acid batteries. This must be done after the reactor fuel is removed, as emergency power may be needed as long as the reactor fuel is loaded in the reactor. The batteries must be removed before the facility can be transferred to EM- 40 .

Method of Accomplishment: The batteries will be removed from Building 7707 and packaged in a manner suitable for transport. The ORNL Waste Management Division or a qualified subcontractor will collect the packages and deliver them to a battery recycling site. Waste Management will be responsible for providing the trucks, cranes, and any other equipment and/or personnel required to remove the material off site.

End Point: Conclusion of this task will occur when the lead-acid batteries have been removed from the TSF site and Waste Management certifies that the batteries have been 
recycled, disposed, or stored in accordance with any and all existing laws and applicable DOE Orders.

\subsubsection{Deactivate unnecessary services}

Deactivate all unnecessary piping, utilities, and alarms as indicated in Sect. 2.3.1.1 (must be done after reactor fuel removal). Evaluate and document all facility safety systems. Deactivate all nonessential systems. It is anticipated that all services to this building may be terminated.

\subsubsection{Fire protection}

No upgrades to the fire protection system are planned. Building 7707 does not have a sprinkler system. The economic value of the building is too low to justify the installation of a sprinkler system.

\subsubsection{Final facility status report}

Prepare the final facility status report as documented in Sect. 2.3.1.3. Since this is an ancillary facility, status will be included in the final facility status report of the primary facility (TSF).

\subsubsection{Building 7708 Butler Building}

\subsubsection{Remove sodium shields}

Remove sodium shielding blocks in the Butler Building (7708) for disposal. The sodium is a potential RCRA and safety issue and must be removed before the facility can be turned over to EM-40. If the shielding blocks were to develop leaks, it would also represent a fire hazard.

Method of Accomplishment: The sodium shields stored in Building 7708 include shields containing clean sodium, containing activated sodium, shields with activated cans, and shields containing mixtures of sodium and depleted uranium. A qualified subcontractor will remove and dispose of the sodium shields. The subcontractor is responsible for the development of a process to safely oxidize the sodium and remove the uranium. The subcontractor will also be responsible for providing the trucks, cranes, and any other equipment and/or personnel required to remove the material off site. The sodium must be melted and repackaged prior to placement aboard the truck, in accordance with the DOT requirements in 49 CFR 172. This task should be completed, if possible, in conjunction with the removal of the sodium in the large outdoor shields on the TSF pad.

End Point: This task will be completed when the sodium shielding blocks have been moved off site and the subcontractor has certified that the sodium, uranium, and aluminum shielding containers have been processed and disposed of in accordance with any and all existing laws and DOE Orders.

\subsubsection{Remove lithium hydride shields}

Remove shielding blocks for disposal. The $\mathrm{LiH}$ must be removed before the facility can be transferred to EM-40. If the shielding blocks leaked, it would also become a fire hazard.

Method of Accomplishment: The LiH shields stored in.Building 7708 include shields with clean lithium hydride and shields with activated aluminum containers. A qualified subcontractor will remove 
dispose of the $\mathrm{LiH}$. The subcontractor will be responsible for providing the trucks, cranes, and any other equipment and/or personnel required to remove the material from the site.

End Point: This task will be completed when the LiH shielding blocks have been moved off site and the subcontractor has certified that the $\mathrm{LiH}$ and the aluminum containers have been processed and disposed of in accordance with any and all existing laws and DOE Orders.

\subsubsection{Deactivate unnecessary services}

Deactivate all unnecessary piping, utilities, and alarms as indicated in Sect. 2.3.1.1. Evaluate and document all facility safety systems. Deactivate all nonessential systems. It is anticipated that all services to this building may be terminated.

\subsubsection{Fire protection}

No upgrades to the fire protection system are planned. Building 7708 does not have a sprinkler system. Until the sodium and $\mathrm{LiH}$ are removed from the building, a sprinkler system would be hazardous because of the violent reaction sodium and $\mathrm{LiH}$ have with water. After the sodium and $\mathrm{LiH}$ are removed from the building, the economic value of the building will be too low to justify the installation of a sprinkler system.

\subsubsection{Remove control balls}

Remove the six reactor control balls sitting in an open tank. These control balls were heavily activated while they were inside the reactor core and are potentially a dangerous source of radiation. The tank holding them must be frequently monitored to ensure that sufficient water is present to provide adequate shielding. Removing the control balls will eliminate this S\&M requirement and reduce the risk of radiation exposure.

Method of Accomplishment: Concrete or lead shielding will be placed around the tank to allow the control balls to be removed from the tank and packaged for disposal without exposing personnel. A mobile crane will then slowly lift a control ball out of the tank. During this procedure, the radiation will be constantly monitored. If the radiation levels are higher than anticipated, the ball will be immediately lowered back into the tank and work stopped until the situation has been reevaluated. When the control ball has been safely removed from the tank, it will be lowered into a B-25 box for disposal as solid low-level waste (SLLW). This procedure will be repeated for all six control balls. The ORNL Waste Management Division will collect the box and dispose of the material in accordance with all existing laws and relevant DOE Orders.

End Point: The activity will be concluded when the control balls have been removed from the site and Waste Management certifies that the material has been stored or disposed of in accordance with any and all existing laws and DOE Orders.

\subsubsection{Consolidate boneyard}

Conduct radiological surveys of the items in the boneyard/scrapyard. Clean items should be salvaged as scrap metal, where possible, or moved out of the boneyard. For large metal items with only small activated areas, the activated portions should be cut off and the clean portions salvaged as scrap. The Office of Radiation Protection conducts monthly radiological and contamination surveys of the 
boneyard. The time and cost required to complete these surveys can be reduced dramatically by reducing the size of the area that must be monitored.

Method of Accomplishment: Office of Radiation Protection personnel or a qualified subcontractor will conduct a radiological survey of each large item in the boneyard. If only small portions of the item are activated, the activated portions of the item will be cut off. A forklift will lift the clean portions and transport the material to an assembly area outside the boneyard, near the road. After this procedure has been completed for all items in the boneyard, a metal recycling contractor will arrive and remove the clean material for recycling. The subcontractor will be responsible for providing cranes, trucks, and any other equipment or personnel necessary to remove the clean items off site. The forklift will then be used to consolidate the remaining activated items in the boneyard into a smaller contained area. Office of Radiation Protection personnel will adjust the boundaries of the radiation zone accordingly.

End Point: This activity will be completed when (1) all major items in the boneyard/scrapyard have been surveyed; (2) the clean items have been removed from the site, and the subcontractor has certified that the metal has been recycled or disposed of according to all existing laws and DOE Orders; and (3) the boneyard has been consolidated into a smaller area.

\subsubsection{Final facility status report}

Prepare the final facility status report as documented in Sect. 2.3.1.3. Since this is an ancillary facility, status will be included in the final facility status report of the primary facility (TSF).

\subsubsection{Building 7716 Tower Shielding, Pool Pump, and Filter House}

\subsubsection{Deactivate unnecessary services}

Deactivate all unnecessary piping, utilities, and alarms as indicated in Sect. 2.3.1.1 (must be done after reactor fuel removal). Evaluate and document all facility safety systems. Deactivate all nonessential systems. It is anticipated that all services to this building may be terminated.

\subsubsection{Final facility status report}

Prepare the final facility status report as documented in Sect. 2.3.1.3. Since this is an ancillary facility, status will be included in the final facility status report of the primary facility (TSF).

\subsection{HIGH RADIATION LEVEL ANALYTICAL FACILITY (3019B)}

Unlike the other three high risk ranking facilities, Building 3019B contains no large inventories of toxic or radioactive materials. However, the facility shares a common wall, utilities, and ventilation with Building 3019A. Consequently, the important endpoints of the deactivation of Building 3019B are completion of the repairs to the roof and ventilation system, the removal of transferrable contamination, and the bonding of fixed contamination in the back cell areas.

\subsubsection{Building 3019B}

The High Radiation Level Analytical Facility does not include any ancillary facilities. All deactivation activities performed at this facility pertain to Building 3019B. 


\subsubsection{Install roof drains}

Install or repair roof drains as necessary. The roof of Building 3019B has settled, and the existing roof drains are no longer in the lowest portions of the roof. This has caused water to collect on portions of the roof after rains and has caused the roof to leak. Since the drains in the building have been plugged, rain water coming in from leaks in the roof can wash transferrable contamination from the area behind the hot cells outside the building, causing environmental insult and exposing plant personnel.

Method of Accomplishment: P\&E personnel or a qualified subcontractor will survey the roof to determine which portions of the roof have the lowest elevations and require the installation of drains. The roof will be punctured in the appropriate locations and the drain pipes installed. The drains will discharge outside the building.

End Point: This activity will be completed when all local depressions in the roof elevation have an operable drain in them and no leaks are occurring.

\subsubsection{Repair roof}

Repair roof leaks near roof hatch, conveyer penetration, and other places where necessary. The purpose of this activity is to prevent rain water from washing transferrable contamination from the area behind the cells out of the building, causing environmental insult and exposing plant personnel.

Method of Accomplishment: Survey and locate leak locations, remove loose material and clean the area, and apply roof patch as needed. Seal remaining small cracks and fissures with tar pitch. After completion of these repairs, the repaired roof will be tested. If this test reveals any remaining deficiencies, additional patching will be applied.

End Point: This activity will be completed when the roof no longer allows noticeable rainwater penetration into the facility.

\subsubsection{Characterize ventilation exhaust header}

Remotely inspect interior of hot cell ventilation header. Some corrosion has been observed on the outside of ventilation header, but it is not known whether the corrosion extends all the way through to the duct interior. (The portion of the exhaust duct that is outside the building has been replaced recently, so this only involves the portion of the exhaust header that is inside the building.) While no actions may be necessary, if the inspection indicates that the corrosion represents an imminent danger, the problem must be rectified. If possible, only remedial patching will be done. If the deterioration is too great to be remedied by patching, the header will be replaced.

Method of Accomplishment: A remote-controlled robot will traverse the course of the ductwork, transmitting images of the pipe interior. After collecting the data, an assessment of the extent of the damage will be made. Methods for repairing the damage, if necessary, will be identified and evaluated, and the optimum solution implemented. The method of accomplishment for the repairs cannot be determined until the extent of the damage is known. It is possible that no further action will be required.

End Point: This task will be completed when it is verified that the corrosion in the exhaust duct no longer represents a credible threat to the safety envelope of the facility. 


\subsubsection{Encapsulate roof conveyer}

Build a structure around the conveyer on the roof to protect it from weather and to provide additional containment. Several contaminated samples that were carried through the conveyer spilled while in transit. If the conveyer were to leak or breach, the contamination would be released to the environment. By placing a superstructure over the conveyer, the conveyer is protected and secondary containment added.

Method of Accomplishment: A wooden or metal covering will be built around the conveyer. This structure will be bolted to the roof in a few places to prevent wind from removing it, but it will be designed to be easily removable so that it won't be a hindrance to eventual D\&D operations.

End Point: This task will be completed when a protective structure covers the portion of the conveyer above Building 3019B.

\subsubsection{Dike exterior doors}

Dike the doors and install a drainage tank, with appropriate alarms, to drain any water accumulating in the building. The purpose of this activity is to prevent accumulated water from washing contamination from the area behind the hot cells into the environment. This is necessary because all the floor drains in the facility have been plugged and disconnected.

Method of Accomplishment: A solid concrete dike will be placed across the base of each exterior doorway. A survey will be conducted to locate the lowest point along the outside edge of the building. A pipe will be installed at this point, discharging accumulated water into a 100-gal tank installed and located outside the building. Any necessary upgrades to the existing floor flood monitors will also be completed.

Endpoint: This task will be completed when the doors are diked and the drain and tank have been installed in the appropriate comer.

\subsubsection{Install air monitors}

Install remote monitoring devices so that the Health Physics personnel will not have to enter the area behind the cells to take air samples. This activity will eliminate the need for Health Physics personnel to enter the area behind the cells twice a week as they now do. Because of the time consumed in dressing out to enter a radiological area, this will result in a significant savings in S\&M costs.

Method of Accomplishment: The sampling device will be mounted along the wall adjacent to the interlock area between the front cell faces and the back cell loading areas.

End Point: This task will be completed when air samples can be taken from outside the hot cell loading area behind the cells.

\subsubsection{Deactivate unnecessary services}

Deactivate all unnecessary piping, utilities, and alarms as indicated in Sect. 2.3.1.1. Evaluate and document all facility safety systems. Deactivate all nonessential systems. It is anticipated that the cell ventilation system, the building ventilation system, the heating system, and the sprinkler system will be maintained. 


\subsubsection{Fire protection}

No upgrades to the sprinkler system are anticipated. There is no need to convert to a dry sprinkler system since the heating system will be maintained. The heating system of Building 3019B is integrated with Building 3019A, so heating cannot be discontinued as long as Building 3019A remains operational.

\subsubsection{Final facility status report}

Prepare the final facility status report as documented in Sect. 2.3.1.3.

Method of Accomplishment: Document all characterization and survey maps, and redline facility drawings to reflect all system and facility changes.

End Point: This task will be completed when the final facility status report has been issued and has been approved by DOE Headquarters.

\subsection{INTEGRATED PROCESS DEMONSTRATION FACILITY (IPDF) (7062)}

IPDF does not contain any spent fuel. The major activities required for Building 7602 have to do with removal of the inventory of hazardous and radiological material and transferrable contamination.

\subsubsection{Building 7602}

Unlike the reactor facilities (TSF and BSF), IPDF does not include any ancillary facilities. All deactivation activities performed at this facility pertain to Building 7602.

\subsubsection{Remove uranyl nitrate}

Remove the remaining drums of concentrated uranyl nitrate solutions. The uranyl nitrate solutions must be removed before the facility can be transferred to EM-40.

Method of Accomplishment: The uranyl nitrate solutions are already packaged in 55-gal drums suitable for transport. Potential disposal locations for the material will be identified. These disposition alternatives will be assessed and evaluated, and the optimum option implemented.

End Point: This activity will be complete when all the drums of uranyl nitrate solution have been removed from Building 7602 and it has been certified that the material has been disposed of in accordance with all existing laws and applicable DOE Orders.

\subsubsection{Decontaminate selected basement areas}

Decontaminate contaminated basement floors as necessary. The contamination in certain areas may interfere with $S \& M$ activities and increase $S \& M$ costs by forcing $S \& M$ personnel to dress out in protective clothing before they can enter the area.

Method of Accomplishment: An assessment will be done to determine which contaminated areas will interfere with S\&M activities. In portions of the building where the reduced S\&M costs from this activity justify the expense of decontaminating the areas, the affected sections of the floor will be rinsed down. The water will be collected and put into the ORNL LLLW system. 
End Point: This activity will be completed when transferrable contamination has been removed from areas that are frequently accessed by personnel carrying out S\&M activities.

\subsubsection{Deactivate unnecessary services}

Deactivate all unnecessary piping, utilities, and alarms as indicated in Sect. 2.3.1.1. Evaluate and document all facility safety systems. Deactivate all nonessential systems.

\subsubsection{Fire protection}

No upgrades to the sprinkler system are anticipated. There is no need to convert to a dry sprinkler system because the heating system will be maintained. The HVAC system of Building 7602 is integrated with Building 7603, so heating cannot be discontinued while Building 7603 remains operational.

\subsubsection{Final facility status report}

Prepare the final facility status report as documented in Sect. 2.3.1.3.

Method of Accomplishment: Document all characterization and survey maps, and redline facility drawings to reflect all system and facility changes.

End Point: This task will be completed when the final facility status report has been issued and has been approved by DOE Headquarters.

\subsection{BULK SHIELDING FACILITY (BSF)}

BSF contains enriched Bulk Shielding Reactor and Oak Ridge Research Reactor fuel that will be transferred to SRS prior to transfer of the facility to EM-40. Other endpoint criteria are facility decontamination, full characterization of Building 3004, and characterization of BSF following fuel removal.

\subsubsection{Building 3010 - BSF}

\subsubsection{Characterize BSF}

Carry out a full characterization of the facility including ancillaries. A full characterization as necessary of the facilities and ancillaries will document and provide a baseline of the radioactive contamination present in those facilities. This document will aid in the endpoint development for deactivation activities.

Method of Accomplishment: Develop characterization plan, perform surveys internal, perform surveys external, and map and regulate facility to reflect characterization.

End Point: The end point will be when the facility and ancillaries are fully characterized and documented. 


\subsubsection{Repair roof}

Repair existing leaks in the roof to prevent rain and snow melt water from entering the facility.

Method of Accomplishment: Survey and locate leak locations, remove loose material and clean the lean area, and apply roof patch as needed. Seal remaining small cracks and fissures with tar pitch. After completion of these repairs, the repaired roof will be tested by pouring water over it. If this test reveals any remaining deficiencies, additional patching will be applied.

End Point: This activity will be completed when the roof no longer allows rainwater penetration into the facility.

\subsubsection{Decontaminate crane}

Decontaminate the crane in the reactor pool bay (must be done before fuel removal). This activity will prevent the spread of radioactive contamination during the reactor fuel removal process.

Method of Accomplishment: The extent of radioactive contamination on the crane will have to be determined during the facility characterization. Using this information, a decontamination plan will be developed to determine the portions of the crane that must be decontaminated prior to crane operation. After implementation of the decontamination plan, the crane will be recharacterized and certified to verify its condition and place it in use.

End Point: The end point will be when radioactive contamination present on the crane is prevented from spreading during the fuel removal process and crane operation.

\subsubsection{Remove reactor fuel}

Remove reactor fuel located in the Reactor Pool Bay. The reactor fuel will be sent for permanent disposition to SRS, to a new dry storage facility in Oak Ridge, or to another facility designated by DOE. Removing reactor fuel from the site will reduce the risk, liability, and S\&M cost associated with the facility.

Method of Accomplishment: A list of disposition options for the fuel will be identified. These options will include leaving the fuel in place until SRS or other spent fuel repository is able to accept the material, building a dry storage facility at ORNL, and moving the fuel to High Flux Isotype Reactor, the BSF, or the Oak Ridge Research Reactor for interim storage. The merits of each option will be studied, assessed, and evaluated. After the optimum plan is selected, a fuel removal plan will be prepared and implemented.

End Point: The end point of the activity will be when the fuel has been accepted by SRS, or other facility designated by DOE and acceptance has been certified.

\subsubsection{Remove heavy water}

Remove and dispose of the tritium-contaminated $\mathrm{D}_{2} \mathrm{O}$ stored in the BSF pool. The heavy water is contaminated with tritium, and EM- 40 acceptance criteria require all hazardous and radiological material be removed prior to transfer of the facility to the $D \& D$ program. 
Method of Accomplishment: The tritium levels in the heavy water will be characterized. Potential disposition locations for the $\mathrm{D}_{2} \mathrm{O}$ will then be identified. The merits of each disposition option will be evaluated and assessed. A removal and disposal plan will be drafted, identifying the optimum disposition alternative. The $\mathrm{BSF}$ crane will remove the $\mathrm{D}_{2} \mathrm{O}$ from the pool and package it in the appropriate shipping containers, in sccordance with applicable DOT regulations. The material will then be shipped off to the location specified in the $\mathrm{D}_{2} \mathrm{O}$ removal and disposal plan.

End Point: This task will be concluded when material has been shipped off site and it has been certified that the material has been disposed of or stored according to all applicable laws and DOE Orders.

\subsubsection{Remove radioactive sources}

Remove and dispose of the radioactive sources kept in the pool. Removing the sources would eliminate the need to monitor the area weekly.

Method of Accomplishment: Possible disposal locations will be identified and an assessment made of the optimum location chosen. The sources are currently stored in a retrievable form. The sources will be removed in the manner specified by the relevant procedures and then shipped to the chosen disposal site in accordance with all applicable laws and DOT regulations. This activity should be done in conjunction with the removal of the radioactive sources stored in the 7702 Control House and the 7700B OSSA.

End point: The end point of this activity will be when the sources are removed from the BSF and it has been certified that the material has been disposed of or stored in accordance with any and all existing laws and applicable DOE Orders.

\subsubsection{Remove fission chambers}

Remove and dispose of the fission chambers stored within a cabinet in the reactor bay room. Removing the chambers would be in compliance with EM-40 acceptance criteria of removing hazardous and radiological inventories from a facility prior to transfer.

Method of Accomplishment: The fission chambers have decayed to the point that they can be disposed of as low-level waste. The chambers will be packaged in appropriate shipping containers and removed from the facility. The ORNL Waste Management Division will collect the package and dispose of it in accordance with all applicable regulations and site policies.

End Point: The end point of this activity will be when the chambers are removed from the BSF and Waste Management certifies that the material has been disposed of in accordance with all existing laws and relevant DOE Orders.

\subsubsection{Remove surplus material}

Remove surplus, unanchored equipment, office trash, etc. Removing surplus, unanchored equipment prior to transfer to D\&D is required by EM-40 acceptance criteria.

Method of Accomplishment: Office of Radiation Protection personnel or a qualified subcontractor will survey all surplus unanchored equipment and furniture. Uncontaminated items will be removed from the facility, loaded onto trucks, and shipped to surplus sales. Lightly contaminated equipment will be 
evaluated to determine if the items possess sufficient economic value to justify the expenses of decontaminating them. Such items will be decontaminated by properly trained radiation workers, removed from the building, and shipped to surplus sales. Remaining contaminated surplus equipment will be compacted, packaged in B-25 boxes, and removed from the building. The ORNL Waste Management Division will collect the boxes and dispose of the material in accordance with all pertinent regulations and site policies.

End Point: The end point will be when all surplus, unanchored equipment is removed from the BSF and Waste Management certifies that all SLLW has been disposed in accordance with any and all existing laws and DOE Orders.

\subsubsection{Bond transferrable contamination}

Remove or bond transferrable contamination in the reactor bay, as necessary. Removing or bonding transferrable contamination in areas frequently accessed by personnel performing routine S\&M activities would rechuce the monitoring requirements in the facility and lower the cost for other S\&M activities by decreasing the protective clothing requirements.

Method of Accomplishment: Review facility characterization maps and evaluate the impact the contamination in each area will have on S\&M activities. Determine in which areas the reduction in S\&M costs from decontaminating them will justify the expense of the decontamination activities. Develop a decontamination plan for these areas only. Remove transferrable contamination in these S\&M work areas by bonding and peeling. Package and dispose of contaminated bonding material into B-25 boxes and remove the boxes from the building. The ORNL Waste Management Division will collect and dispose of B-25 boxes in accordance with all current regulation and site policies. Resurvey the decontaminated areas, as needed, to update the facility characterization and revise S\&M Health Physics requirements as appropriate.

End Point: The end point of this activity will be when transferrable contamination is removed or bonded in S\&M work areas and Waste Management has certified that all low-level waste generated from the decontamination activities has been disposed of in accordance with any and all existing laws and DOE Orders.

\subsubsection{Deactivate unnecessary services}

Deactivate all unnecessary piping, utilities, and alarms as indicated in Sect. 2.3.1.1 (must be done after reactor fuel removal). Evaluate and document all facility safety systems, and deactivate all nonessential safety systems.

\subsubsection{Fire protection}

Develop conversion plan of wet sprinkler system to dry system, change fire header control valve and other equipment including addition of an air compressor for system conversion, and document fire system alterations.

\subsubsection{Final facility status report}

Prepare the final facility status report as documented in Sect. 2.3.1.3. Document all characterization and survey maps; redline facility drawings to reflect all system and facility changes. 


\subsubsection{Building 3004 Water Demineralizer}

Although Building 3004 is an ancillary of BSF, it also provides demineralized water to other facilities, including Building 3042, Building 3005, and Building 7700. Since these requirements will continue after the deactivation of BSF, Building 3004 will be kept operational for the foreseeable future or until arrangements are made to provide all facilities supported by Building 3004 with alternate sources of demineralized water.

\subsubsection{Salvage Tanks 3004A, 3004B, 3004C, 3004D, 3004F, and 3004H}

Tanks 3004A, 3004B, 3004C, 3004D, 3004F, and 3004H are no longer being used. However, while the tanks remain at the site, they must be periodically monitored to verify that no one is using the tanks for unauthorized disposal of hazardous materials. Removing the tanks from the site eliminates this surveillance requirement.

Method of Accomplishment: An Office of Radiation Protection representative or a qualified subcontractor will survey the tanks, decontaminate the exterior as needed, and green-tag the tanks. A metal recycling subcontractor will remove the tanks and transport them off site for salvage as scrap. The subcontractor will be responsible for providing trucks, hoists, and any other equipment required to remove the tanks from the building and load them for transport. These tanks are not required for current operations in Building 3004, and can be removed immediately.

End Point: This task will be completed when the tanks are removed from the facility and the subcontractor certifies that they have been recycled or disposed of in accordance with any and all existing laws and DOE Orders.

\subsubsection{Salvage outdoor water tank}

Disconinect and drain all piping to the 10,000 -gal, outdoor, demineralized water tank. Green-tag the tank and salvage the steel as scrap. The outdoor, 10,000-gal tank is no longer necessary to the operation of the demineralizer. Water currently flowing into this tank can be rerouted to go directly into ORNL's sanitary wastewater system. This would eliminate the expenses involved in periodically send a truck to drain this tank and dispose of the water. In addition, while the tank remains at the site, it must be periodically monitored to verify that no one is using the tank for unauthorized disposal of hazardous materials. Removing the tank from the site eliminates this surveillance requirement.

Method of Accomplishment: Additional water lines connecting the piping to the tank with ORNL's sanitary wastewater system will be installed. After rerouting the water flow, the old lines leading to the tank will be drained and capped. Any water accumulated in the tank will be drained and disposed of in ORNL's sanitary wastewater system. An Office of Radiation Protection representative or a qualified subcontractor will survey the tank, decontaminate the exterior as needed, and green-tag the tank. A metal recycling subcontractor will remove the tank and transport it off site for salvage as scrap. The subcontractor will be responsible for providing trucks, hoists, and any other equipment required to remove the tank and load it for transport. This tank is not required for current operations in Building 3004 and can be removed immediately. This task should be performed in conjunction with the removal of the other surplus tanks from BSF and its ancillaries.

End Point: This task will be completed when the tank is removed from the facility and the subcontractor certifies that it has been recycled in accordance with any and all existing laws and DOE Orders. 


\subsubsection{Bond transferrable contamination}

Decontaminate and bond transferrable contamination in the facility, as needed. Removing or bonding transferrable contamination in areas frequently accessed by personnel performing routine S\&M activities would reduce the monitoring requirements in the facility and lower the cost for other S\&M activities by decreasing the protective clothing requirements.

Method of Accomplishment: Review facility characterization maps and evaluate the impact the contamination in each area will have on S\&M activities. Determine in which areas the reduction in S\&M costs from decontaminating them will justify the expense of the decontamination activities. Develop a decontamination plan for these areas only. Remove transferrable contamination in these S\&M work areas by bonding and peeling. Package and dispose of contaminated bonding material into B-25 boxes, and remove the boxes from the building. The ORNL Waste Management Division will collect and dispose of B-25 boxes in accordance with all current regulation and site policies. Resurvey the decontaminated areas, as needed, to update the facility characterization and revise S\&M Health Physics requirements as appropriate.

End Point: The end point of this activity will be when transferrable contamination is removed or bonded in S\&M work areas and Waste Management has certified that all low-level waste generated from the decontamination activities has been disposed of in accordance with any and all existing laws and DOE Orders.

\subsubsection{Remove surplus equipment}

Remove all loose, unanchored surplus equipment from the first floor. The resin beds will need to remain to treat the water until the demineralizer is eventually shut down. All other equipment may be removed immediately.

Method of Accomplishment: Office of Radiation Protection personnel will survey all surplus unanchored equipment and furniture. Uncontaminated items will be removed from the facility, loaded onto trucks, and shipped to surplus sales. Lightly contaminated equipment will be evaluated to determine if the items possess sufficient economic value to justify the expenses of decontaminating them. Such items will be decontaminated by properly trained radiation workers, removed from the building, and shipped to surplus sales. Remaining contaminated surplus material will be compacted, where possible, packaged in B-25 boxes and removed from the building. The ORNL Waste Management Division will collect the boxes and dispose of the material in accordance with all pertinent regulations and site policies.

End Point: The end point will be when all surplus, unanchored equipment is removed from Building 3004 and Waste Management certifies that all SLLW has been disposed of in accordance with any and all existing laws and DOE Orders. (The resin beds are not surplus equipment).

\subsubsection{Deactivate unnecessary services}

Deactivate all unnecessary piping, utilities, and alarms as indicated in Sect. 2.3.1.1 (must be done after reactor fuel removal). Evaluate and document all facility safety systems. Deactivate all nonessential systems. 


\subsubsection{Fire protection}

No upgrades to the fire protection system are planned. The building currently has a wet sprinkler system. There is no need to convert to a dry sprinkler system, because Building 3004 must remain heated and operational until all the facilities it supports acquire alternative sources of demineralized water.

\subsubsection{Final status report}

Prepare the final facility status report as documented in Sect. 2.3.1.3. Document all characterization and survey maps; redline facility drawings to reflect all system and facility changes. Although Building 3004 is an ancillary of BSF, a separate final facility status report will be issued for this building because its deactivation will occur so much later than that of Building 3010 and the other BSF ancillaries.

\subsubsection{Building 3009 BSF Pumphouse}

\subsubsection{Roof repair}

Repair leaks in the roof as necessary. The roof must be structurally sound and in good repair to prevent rain and snow melt water from entering the facility and washing contamination outside where it would cause environmental insult and expose plant personnel.

Method of Accomplishment: Survey and locate leaks, remove loose material and clean the lean area, and apply roof patch as needed. Seal remaining small cracks and fissures with tar pitch. After completion of these repairs, the repaired roof will be tested by pouring water over it. If this test reveals any remaining deficiencies, additional patching will be applied.

End Point: This activity will be completed when the roof no longer allows noticeable rainwater penetration into the facility.

\subsubsection{Remove waste material}

Remove contaminated material on the floor and dispose of them as low-level waste. The removal of combustible and contaminated materials reduce the S\&M cost associated with the facility.

Method of Accomplishment: Package all loose material and characterize as needed. Dispose of all noncontaminated material as general waste. Compact and dispose of contaminated items as solid low-level waste. The Waste Management Division will collect and dispose of the material in accordance with all applicable regulations and site policies.

End Point: The end point of this activity will be when materials are removed from the facility and Waste Management certifies that the materials have been disposed of in accordance with any and all existing laws and DOE Orders.

\subsubsection{Remove gross levels of contamination and bond transferrable contamination}

Remove gross levels of transferrable contamination from the floor, walls, and remaining equipment. Paint bond the remaining contamination in the facility, as necessary. Removing gross contamination and bonding remaining transferrable contamination in areas frequently accessed by personnel performing 
routine S\&M activities would reduce the monitoring requirements in the facility and lower the cost for other S\&M activities by decreasing the protective clothing requirements.

Method of Accomplishment: Review facility characterization maps and evaluate the impact the contamination in each area will have on S\&M activities. Determine in which areas the reduction in S\&M costs from decontaminating them will justify the expense of the decontamination activities. Develop a decontamination plan for these areas only. Utilize traditional cleaning and bonding practices. Package and dispose of contaminated material B-25 boxes and remove the boxes from the building. The ORNL Waste Management Division will collect and dispose of or store B-25 boxes in accordance with all current regulation and site policies. LLLW will be disposed of in the ORNL LLLW treatment system. Resurvey the decontaminated areas, as needed, to update the facility characterization and revise S\&M Health Physics requirements as appropriate.

End Point: The end point of this activity will be when transferrable contamination is removed or bonded in S\&M work areas and Waste Management has certified that all low-level waste generated from the decontamination activities has been disposed of or stored in accordance with any and all existing laws and DOE Orders.

\subsubsection{Deactivate unnecessary services}

Deactivate all unnecessary piping, utilities, and alarms as indicated in Sect. 2.3.1.1. Evaluate and document all facility safety systems. Deactivate all nonessential systems. Evaluate and document all facility safety systems.

\subsubsection{Provide fire protection}

No upgrades to the fire protection system are planned. Building 3009 currently has no sprinkler system. The economic value of the building is too low to justify the installation of a new sprinkler system.

\subsubsection{Final facility status report}

Prepare the final facility status report as documented in Sect. 2.3.1.3. Since this is an ancillary facility, status will be included in the final facility status report of the primary facility (BSF).

\subsubsection{Building 3088 Storage BSF}

No deactivation activities are planned for this facility.

\subsubsection{Final facility status report}

Prepare the final facility status report as documented in Sect. 2.3.1.3. Since this is an ancillary facility, status will be included in the final facility status report of the primary facility (BSF).

\subsubsection{Building 3101 Storage Shed BSF}

\subsubsection{Bond transferrable contamination}

Bond transferrable contamination in S\&M areas in the building, as necessary. Removing or bonding transferrable contamination in areas frequently accessed by personnel performing routine S\&M activities 
would reduce the monitoring requirements in the facility and lower the cost for other S\&M activities by decreasing the protective clothing requirements.

Method of Accomplishment: Review facility characterization maps to evaluate the impact the contamination in each area will have on S\&M activities. Determine in which areas the reduction in S\&M costs from decontaminating them will justify the expense of the decontamination activities. Develop a decontamination plan for these areas only. Remove transferrable contamination in these S\&M work areas by bonding and peeling. Package and dispose of contaminated bonding material into B-25 boxes and remove the boxes from the building. The ORNL Waste Management Division will collect and dispose of B-25 boxes in accordance with all current regulation and site policies. Resurvey the decontaminated areas, as needed, to update the facility characterization and revise S\&M Health Physics requirements as appropriate.

End Point: The end point of this activity will be when transferrable contamination is removed or bonded in S\&M work areas and Waste Management has certified that all low-level waste generated from the decontamination activities has been disposed of in accordance with any and all existing laws and DOE Orders.

\subsubsection{Remove surplus equipment}

Remove and dispose of surplus equipment (e.g., pumps) sitting outside the building. Removing surplus, unanchored equipment prior to transfer to $D \& D$ is required by EM-40 acceptance criteria.

Method of Accomplishment: Office of Radiation Protection personnel will survey all surplus unanchored equipment and furniture. Uncontaminated items will be removed from the facility, loaded onto trucks, and shipped to surplus sales. Lightly contaminated equipment will be evaluated to determine if the items possess sufficient economic value to justify the expenses of decontaminating them. Such items will be decontaminated by properly trained radiation workers, removed from the building, and shipped to surplus sales. Remaining contaminated surplus equipment will be compacted, packaged in B-25 boxes, and removed from the building. The ORNL Waste Management Division will collect the boxes and dispose of the material in accordance with all pertinent regulations and site policies.

End Point: The end point will be when all surplus, unanchored equipment is removed from Building 3101 and Waste Management certifies that all SLLW has been disposed of in accordance with any and all existing laws and DOE Orders.

\subsubsection{Remove unidentified waste}

Remove and dispose eight bags of unidentified waste stored in the building. Removing combustible materials reduces the risk and liability associated with the building, and removal of hazardous and radiological materials is required by EM-40 acceptance criteria.

Method of Accomplishment: The bags will be examined to determine what types of waste they contain. After the contents have been characterized, the appropriate containers for disposal will be obtained. The waste will be packaged for transport off site and removed from the building. The ORNL Waste Management Division will collect the packages and dispose of the material in accordance with the relevant regulations and site policies. 
End Point: The end point of this activity will be when all waste materials are removed and Waste Management has certified that the material has been disposed of or stored in accordance with any and all existing laws and DOE Orders.

\subsubsection{Deactivate unnecessary services}

Deactivate all unnecessary piping, utilities, and alarms as indicated in Sect. 2.3.1.1. Evaluate and document all facility safety systems. Deactivate all nonessential systems. It is anticipated that all services to the building may be discontinued.

\subsubsection{Fire protection}

No upgrades to the fire protection system are planned. Building 3101 does not have a sprinkler system. The economic value of the building is too low to justify the installation of a sprinkler system.

\subsubsection{Final facility status report}

Prepare the final facility status report as documented in Sect. 2.3.1.3. Since this is an ancillary facility, status will be included in the final facility status report of the primary facility (BSF).

\subsubsection{Building 3117 BSF Cooling Tower}

\subsubsection{Salvage Tank 3117A}

Characterize and green-tag Tank 3117A; salvage as scrap metal. Tank 3117A is no longer being used. However, while the tank remains at the site, it must be periodically monitored to verify that no one is using the tank for unauthorized disposal of hazardous materials. Removing the tank from the site eliminates this surveillance requirement.

Method of Accomplishment: An Office of Radiation Protection representative or a qualified subcontractor will survey the tank, decontaminate the exterior as needed, and green-tag the tank. A metal recycling subcontractor will remove the tank and transport it off site for salvage as scrap. The subcontractor will be responsible for providing trucks, hoists, and any other equipment required to remove the tank and load it for transport. This task should be performed in conjunction with the removal of the other surplus tanks from BSF and its ancillaries.

End Point: This task will be completed when the tank is removed from the facility and the subcontractor certifies that it has been recycled in accordance with any and all existing laws and DOE Orders.

\subsubsection{Deactivate unnecessary utilities}

Deactivate all unnecessary piping, utilities, and alarms as indicated in Sect. 2.3.1.1 (must be done after reactor fuel removal). Evaluate and document all facility safety systems. Deactivate all nonessential systems. It is anticipated that all services to the building may be discontinued.

\subsubsection{Final facility status report}

Prepare the final facility status report as documented in Sect. 2.3.1.3. Since this is an ancillary facility, status will be included in the final facility status report of the primary facility (BSF). 


\subsubsection{Tank A-1204 Liquid Nitrogen Tank}

\subsubsection{Salvage Tank A-1204}

Green-tag Tank A-1204 and salvage as scrap metal. Tank A-1204 is no longer being used. However, while the tank remains at the site, it must be periodically monitored to verify that no one is using the tank for unauthorized disposal of hazardous materials. Removing the tank from the site eliminates this surveillance requirement.

Method of Accomplishment: An Office of Radiation Protection representative or a qualified subcontractor will survey the tank, decontaminate the exterior as needed, and green-tag the tank. A metal recycling subcontractor will remove the tank and transport it off site for salvage as scrap. The subcontractor will be responsible for providing trucks, hoists, and any other equipment required to remove the tank and load it for transport. This task should be performed in conjunction with the removal of the other surplus tanks from BSF and its ancillaries.

End Point: This task will be completed when the tank is removed from the facility and the subcontractor certifies that it has been recycled in accordance with any and all existing laws and DOE Orders.

\subsubsection{Tank 13822 Liquid Helium Tank}

\subsubsection{Salvage Tank 13822}

Green-tag Tank 13822 and salvage as scrap metal. Tank 13822 is no longer being used. However, while the tank remains at the site, it must be periodically monitored to verify that no one is using the tank for unauthorized disposal of hazardous materials. Removing the tank from the site eliminates this surveillance requirement.

Method of Accomplishment: An Office of Radiation Protection representative or a qualified subcontractor will survey the tank, decontaminate the exterior as needed, and green-tag the tank. A metal recycling subcontractor will remove the tank and transport it off site for salvage as scrap. The subcontractor will be responsible for providing trucks, hoists, and any other equipment required to remove the tank and load it for transport. This task should be performed in conjunction with the removal of the other surpius tanks from BSF and its ancillaries.

End Point: This task will be completed when the tank is removed from the facility and the subcontractor certifies that it has been recycled in accordance with any and all existing laws and DOE Orders.

\subsubsection{Building 3098 BSF Filter Facility}

\subsubsection{Bond transferrable contamination}

Bond transferrable contamination in S\&M areas of the facility, as necessary. Removing or bonding transferrable contamination in areas frequently accessed by personnel performing routine S\&M activities would reduce the monitoring requirements in the facility and lower the cost for other S\&M activities by decreasing the protective clothing requirements. 
Method of Accomplishment: Review facility characterization maps and evaluate the impact the contamination in each area will have on S\&M activities. Determine in which areas the reduction in S\&M costs from decontaminating them will justify the expense of the decontamination activities. Develop a decontamination plan for these areas only. Remove transferrable contamination in these S\&M work areas by bonding and peeling. Package and dispose of contaminated bonding material into B-25 boxes and remove the boxes from the building. The ORNL Waste Management Division will collect and dispose of B-25 boxes in accordance with all current regulation and site policies. Resurvey the decontaminated areas, as needed, to update the facility characterization and revise S\&M Health Physics requirements as appropriate.

End Point: The end point of this activity will be when transferrable contamination is removed or bonded in S\&M work areas and Waste Management has certified that all low-level waste generated from the decontamination activities has been disposed of in accordance with any and all existing laws and DOE Orders.

\subsubsection{Deactivate unnecessary services}

Deactivate all unnecessary piping, utilities, and alarms as indicated in Sect. 2.3.1.1. Evaluate and document all facility safety systems. Deactivate all nonessential systems. It is anticipated that all services to the building can be discontinued.

\subsubsection{Fire protection}

No upgrades to the fire protection system are planned. Building 3098 does not have a sprinkler system. The economic value of the building is too low to justify the installation of a sprinkler system.

\subsubsection{Final facility status report}

Prepare the final facility status report as documented in Sect. 2.3.1.3. Since this is an ancillary facility, status will be included in the final facility status report of the primary facility (BSF).

\subsubsection{Building 3119 Heat Exchanger and Pumphouse}

\subsubsection{Salvage tanks}

Decontaminate the outside of the two tanks in the building. The interior of the tanks are clean. Green-tag them and salvage them as scrap. These tanks are no longer being used. However, while the tanks remain at the site, they must be periodically monitored to verify that no one is using them for unauthorized disposal of hazardous materials. Removing the tanks from the site eliminates this surveillance requirement.

Method of Accomplishment: An Office of Radiation Protection representative or a qualified subcontractor will survey the tanks, decontaminate the exteriors as needed, and green-tag the tanks. A metal recycling subcontractor will collect the tanks and transport them off site for salvage as scrap. The subcontractor will be responsible for providing trucks, hoists, and any other equipment required to remove the tanks from the building and load it for transport. This task should be performed in conjunction with the removal of the other surplus tanks from BSF and its ancillaries. 
End Point: This task will be completed when the tank is removed from the facility and the subcontractor certifies that it has been recycled or disposed of in accordance with any and all existing laws and DOE Orders.

\subsubsection{Remove surplus equipment}

Remove and dispose of all loose, unanchored surplus equipment. The only equipment in the building that is not surplus is the Motor Control Center, which supports several other buildings. Removing surplus, unanchored equipment prior to transfer to D\&D is required by EM-40 acceptance criteria.

Method of Accomplishment: Office of Radiation Protection personnel or a qualified subcontractor will survey all surplus unanchored equipment and furniture. Uncontaminated items will be removed from the facility, loaded onto trucks, and shipped to surplus sales. Lightly contaminated equipment will be evaluated to determine if the items possess sufficient economic value to justify the expenses of decontaminating them. Such items will be decontaminated by properly trained radiation workers, removed from the building, and shipped to surplus sales. Remaining contaminated surplus equipment will be compacted, packaged in B-25 boxes, and removed from the building. The ORNL Waste Management Division will collect the boxes and dispose of the material in accordance with all pertinent regulations and site policies.

End Point: The end point will be when all surplus, unanchored equipment is removed from Building 3119 and Waste Management certifies that all SLLW has been disposed in accordance with any and all existing laws and DOE Orders. (The Motor Control Center is not surplus equipment).

\subsubsection{Deactivate unnecessary services}

Deactivate all unnecessary piping, utilities, and alarms as indicated in Sect. 2.3.1.1 (must be done after reactor fuel removal). It is anticipated that all services to the building other than the electrical lines to the Motor Control Center can be discontinued. Evaluate and document all facility safety systems. Deactivate all nonessential systems. Evaluate and document all facility safety systems.

\subsubsection{Fire protection}

No upgrades to the fire protection system are planned. Building 7703 does not have a sprinkler system. The economic value of the building is too low to justify the installation of a sprinkler system.

\subsubsection{Final facility status report}

Prepare the final facility status report as documented in Sect. 2.3.1.3. Since this is an ancillary facility, status will be included in the final facility status report of the primary facility (BSF). 


\section{WORK PLANS}

\subsection{WORK BREAKDOWN STRUCTURE (WBS)}

HRFDP WBS defines a hierarchy between elements of HRFDP and reflects the lowest level of work package necessary to complete the project. WBS will be used as a program management tool to

- identify the scope of all work activities;

- plan and schedule work;

- $\quad$ prepare resource budgets to support work;

- develop spending profiles;

- develop subcontract documents; and

- collect technical, schedule, and cost performance data.

Table 4.1 illustrates WBS. All participants will manage and schedule work, collect costs, and evaluate progress in accordance with WBS at the work package level. Appropriate budget and reporting codes will be applied to ensure that roll-up capability within WBS structure is protected.

\subsection{PROJECT BASELINE SCHEDULE}

Energy Systems ER Program is responsible for the preparation and the maintenance of master project schedules. These master project schedules are developed in accordance with the scope defined within ORNL WBS and contain all controlled milestones. The master project schedule is supported by a number of lower-level schedules created to match activities at levels seven, eight, or lower of WBS. The sum of the lower-level schedules make up the baseline utilized by Energy Systems for progress determination and control of milestone accomplishment.

The top-level HRFDP schedule is shown in Fig. ES-1. Schedules for each facility are shown in Appendix B (Subproject Schedules). As shown, HRFDP will be complete in FY 2001. Planned major highlights for FY 1996 are shown in Appendix E. A summary of FY 1996 planned major highlights, their costs, and scheduled completion dates are shown in Table 4.1.

The project team established schedule objectives that address the major milestones incorporated into the schedule. These milestones provide points for overall project management, progress tracking, decision-making, control, and reporting within the master project schedule and lower-level schedules. Project milestones for HRFDP will include start and finish of deactivation of each facility as identified, and result in the production of a final facility report where applicable. All HRFDP milestones are listed in Table 4.2. 
4.1. High Ranking Facilities Deactivation Project-WBSะ 1.6.6.2.10.1

\begin{tabular}{|c|c|}
\hline WBS & Title \\
\hline 1.6 .6 & EM-60" \\
\hline 1.6 .6 .2 & EM-60-0R1 \\
\hline 1.6.6.2.10 & ORNL site \\
\hline 1.6.6.2.10.1.01. & Project integration \\
\hline 1.6.6.2.10.1.02. & $\mathbf{S} \& \mathbf{M}^{\mathbf{b}}$ \\
\hline 1.6.6.2.10.1.02.01 & $\mathrm{BSF}^{\mathrm{c}}(\mathbf{3 0 1 0}) \mathrm{S} \& \mathrm{M}$ \\
\hline 1.6.6.2.10.1.02.01.01 & S\&M planning \\
\hline 1.6.6.2.10.1.02.01.02 & Surveillance \\
\hline 1.6.6.2.10.1.02.01.03 & Maintenance \\
\hline 1.6.6.2.10.1.02.01.04 & Utilities \\
\hline 1.6.6.2.10.1.02.02 & High Radiation Analytical Facility (3019B) S\&M \\
\hline 1.6.6.2.10.1.02.02.01 & S\&M planning \\
\hline 1.6.6.2.10.1.02.02.02 & Surveillance \\
\hline 1.6.6.2.10.1.02.02.03 & Maintenance \\
\hline 1.6.6.2.10.1.02.02.04 & Utilities \\
\hline 1.6.6.2.10.1.02.03 & IPDF (7602) S\&M \\
\hline 1.6.6.2.10.1.02.03.01 & S\&M planning \\
\hline 1.6 .6 .2 .10 .1 .02 .03 .02 & Surveillance \\
\hline 1.6.6.2.10.1.02.03.03 & Maintenance \\
\hline 1.6.6.2.10.1.02.03.04 & Utilities \\
\hline 1.6 .6 .2 .10 .1 .02 .04 & TSR (7700) S\&M \\
\hline 1.6 .6 .2 .10 .1 .02 .04 .01 & S\&M planning \\
\hline 1.6.6.2.10.1.02.04.02 & Surveillance \\
\hline 1.6.6.2.10.1.02.04.03 & Maintenance \\
\hline 1.6.6.2.10.1.02.04.04 & Utilities \\
\hline 1.6 .6 .2 .10 .1 .03 & BSF (3010) deactivation \\
\hline 1.6.6.2.10.1.04 & High Radiation Level Analytical Facility (3019B) deactivation \\
\hline 1.6.6.2.10.1.05 & IPDF 7602 deactivation \\
\hline 1.6.6.2.10.1.06 & TSR$^{*}(7700)$ deactivation \\
\hline
\end{tabular}

'WBS (work breakdown structure) 'EM-60 (U.S. Department of Energy Nuclear and Facility Stabilization Program; 'S\&M (surveillance and maintenance); 'BSF (Bulk Shielding Facility); 'TPDF (Integrated Process Demonstration Facility); 'TSR (Tower Shielding Reactor) 
Table 4.2. High Ranking Facilities Deactivation Project-milestones

\begin{tabular}{|c|c|}
\hline Date & Milestone \\
\hline Feb. 96 & Submit Level $1 \mathrm{~A}$ life cycle baseline cost and schedule to DOE for approval \\
\hline Mar. 96 & Complete alternatives assessment for BSF' fuel removal \\
\hline Aug. 96 & Complete reactor fuel removal alternatives evaluation for $\mathrm{TSF}^{\mathrm{b}}$ \\
\hline Sept. 97 & Project deactivation cost estimates completed \\
\hline Sept. 96 & Complete facility deactivation activities at 7602 Process Demonstration Facility \\
\hline Sept. 97 & BSF fuel removal (per $R_{R} D^{c}$ assumptions) \\
\hline Sept. 98 & TSF fuel removal (per RRD assumptions) \\
\hline May 98 & Complete facility deactivation activities at 3019B high level analytical lab \\
\hline Mar 98 & Complete sodium/lithium removal from the TSFd site \\
\hline May 00 & Complete deactivation activities at the TSF site \\
\hline May 01 & Complete deactivation activities at the BSF site \\
\hline Sept. 03 & Transfer facilities set to EM-40 D\&De Program \\
\hline
\end{tabular}

"BSF (Bulk Shielding Facility); 'TSF (Tower Shielding Facility); RRD (Research Reactors Division); 'D\&D (decontamination and decommissioning)

The schedules will include activities to be performed by other DOE prime participants and subcontractors. On a monthly basis, progress for ongoing activities and future projections will be provided by each prime participant and project team member and will be supplied to the appropriate Energy Systems Project Manager and Scheduler. This information will be used to update the project schedule and assist the Project Analyst in evaluating project status and providing the Project Manager with the information necessary to make informed decisions and the preparation of project reporting activities.

Schedule status will be reviewed by Energy Systems program management, project management, and DOE program management during the normal monthly reporting process required by the monthly status report and progress-tracking system. The WBS system was developed to address the uniqueness of HRFDP. Nevertheless, this structure will provide the best way to track activities and costs and still enable them to be rolled up to the Activity Data Sheet (ADS) level.

\subsection{COST BASELINE}

The cost baseline for the project is a time-phased cost estimate to complete the deactivation activities and turn the facilities over to the D\&D Program. The following were used to develop the cost estimate:

- define the project's technical and end-point criteria;

- identify and schedule the individual work elements required to meet the requirements; 
- systematically organize the work elements in a WBS;

- estimate the resources needed to complete the work elements in WBS using a uniform set of estimating assumptions; and

- assume actual work will be performed by a team of subcontractors.

Total (ADS level) estimated HRFDP costs are summarized in Table ES-1. Detailed cost estimates for each deactivation activity are not yet complete. Project deactivation cost estimates are expected to be complete by the end of FY 1996.

The project cost estimate is referred to as a baseline because it will be integrated with the technical and schedule baseline and is subject to formal change control. This estimate is the sum of the estimates for the individual activities in the control accounts and developed on the automated cost-estimating system.

Annual review of the work plan accommodates changes resulting from revised programmatic requirements, budget constraints, or unplanned conditions or changes. As project work proceeds, the total estimated cost and the total project costs to date and schedules are to be updated to reflect the current estimate at completion for both when each year's ADS is prepared by the HRFDP Project Manager.

The level of confidence in this estimate is similar to that expected at the end of the conceptual design phase of a major project, assuming the work is performed and controlled as described in this report. There have been no major engineering studies performed to assess these project estimates.

\subsubsection{Funding}

The five-year funding plan shown in Table ES-1 is from ADS 6502 as submitted in April 1995, with minor updates. The FY 1996 is unchanged from the original submittal; however, the FYs 1997-2001 were adjusted to compensate for the TSF nuclear spent fuel removal actions completed in FY 1998, per this work plan, instead of FY 1997 as assumed in ADS 6502. HRFDP has performed its own conceptual estimates, which indicate a significant difference between the two. Working together with RRD should help to reduce the differences in dollars, which are partially based on different assumptions.

The work plan includes all known deactivation activities identified at the appropriate facilities as of June 1995. The funding as shown in Table ES-1 does not reflect the funding to implement all of these activities. Therefore, as these and future unknown deactivation activities are evaluated, prioritized, and accepted as viable activities, funding requests will be revised. See Table 4.3 for the conceptual cost estimate and completion date for FY 1996 deactivation activities. 
Table 4.3. High Ranking Facilities Deactivation Project-activities for FY 1996

\begin{tabular}{|c|c|c|c|}
\hline WBS & Deactivation activities & $\begin{array}{l}\text { Conceptual cost estimates } \\
\text { (thousands of dollars) }\end{array}$ & $\begin{array}{c}\text { Scheduled } \\
\text { completion (date) }\end{array}$ \\
\hline 10.1 .01 & Life cycle baseline & 75 & $2 / 96$ \\
\hline 10.1.03.01 & BSF fuel removal evaluation & 200 & $3 / 96$ \\
\hline 10.1.05.01 & $\begin{array}{l}\text { Remove and dispose of uranyl } \\
\text { nitrate at Building } 7602\end{array}$ & 500 & $6 / 96$ \\
\hline 10.1.04.01 & $\begin{array}{l}\text { Patch and evaluate building } \\
\text { 3019B roof }\end{array}$ & 125 & $8 / 96$ \\
\hline 10.1.06.01 & Survey instrument towers at TSF" & 75 & $8 / 96$ \\
\hline 10.1.06.02 & TSF fuel removal evaluation & 200 & $8 / 96$ \\
\hline \multirow[t]{2}{*}{ 10.1.06.03 } & Remove and recycle lead at TSF & 200 & 9/96 \\
\hline & Routine deactivation' ${ }^{1}$ & 150 & 9/96 \\
\hline
\end{tabular}

'Routine deactivation will be performed at all 32 facilities. WBS (work breakdown structure) will be assigned as the actions are identified.

'TSF (Tower Shielding Facility) 
The resource data used to prepare the cost estimate are derived from current cost data and staffing requirements for existing work elements that are expected to continue for the duration of the project and from technical work descriptions and schedules prepared for each deactivation and S\&M activity.

The estimate for each work element was reviewed by knowledgeable plant staff and account for uniformity and reasonableness prior to acceptance into the.cost estimate. However, these conceptual estimates are based on the best information that could be collected in a limited time. As activities are more throughly defined and evaluated, it is expected that additional funding will be necessary to complete all deactivation activities as planned.

The resources were priced using labor rates developed from the existing financial system. The indirect costs, including steam and water use assessments, organization overheads, material procurement, and general and administrative burdens, were developed similarly.

Comparisons of the deactivation resource mix with the existing resource mix were made and the changes reconciled with work content differences. Where necessary, cost allowances were made based on historical usage rates, including materials and MK-Ferguson construction forces.

\subsection{PROJECT ORGANIZATION AND RESPONSIBILITIES}

This project is provided oversight by the DOE ER EM-60 Program Manager and supported by an integrated team of Energy Systems and subcontract personnel and the DOE-ORO EM-60 organization. The following discussion provides functional descriptions of the key management and the support organization that makes up HRFDP. See Fig. 4.1 for HRFDP proposed organizational structure.

The ORNL ER Program is responsible for supporting the HRFDP Project Manager with day-to-day technical support, coordination, control, and reporting of project activities identified in this work plan and other assistance as considered necessary by the Project Manager.

The HRFDP Project Manager plans, coordinates, and schedules activities; directly develops budgets and Activity Data Sheets (ADS); directs project execution, including technical direction; develops and administers project criteria; analyzes the baseline system; schedules, budgets; performs configuration management; and reports. The HRFDP Project Manager receives policy guidance and project instructions from the DOE-ORO Project Manager. The HRFDP Project Manager reports status and progress to the ORNL ER Site Program Director on a regular basis through existing reporting programs. The Project Organization is shown in Fig. 4.1.

\subsubsection{Site ER Program Director}

The organization and structure of ORNL HRFDP will be functional in form and limited in terms of the layers of management. The organization and plan guidelines will be laid out accordingly. (See Fig. 4.1.) Overall, the ER EM-60 Program Manager will provide oversight and assistance as necessary to support the program management of the entire HRFDP transfer to an EM-60 project.

The HRFDP Project Manager will provide report status and progress reports to the ER EM-60 Program Manager and ER Program as necessary through existing reporting programs and will meet with the Program Manager on an appropriate basis for a one-on-one discussion concerning how the Program 


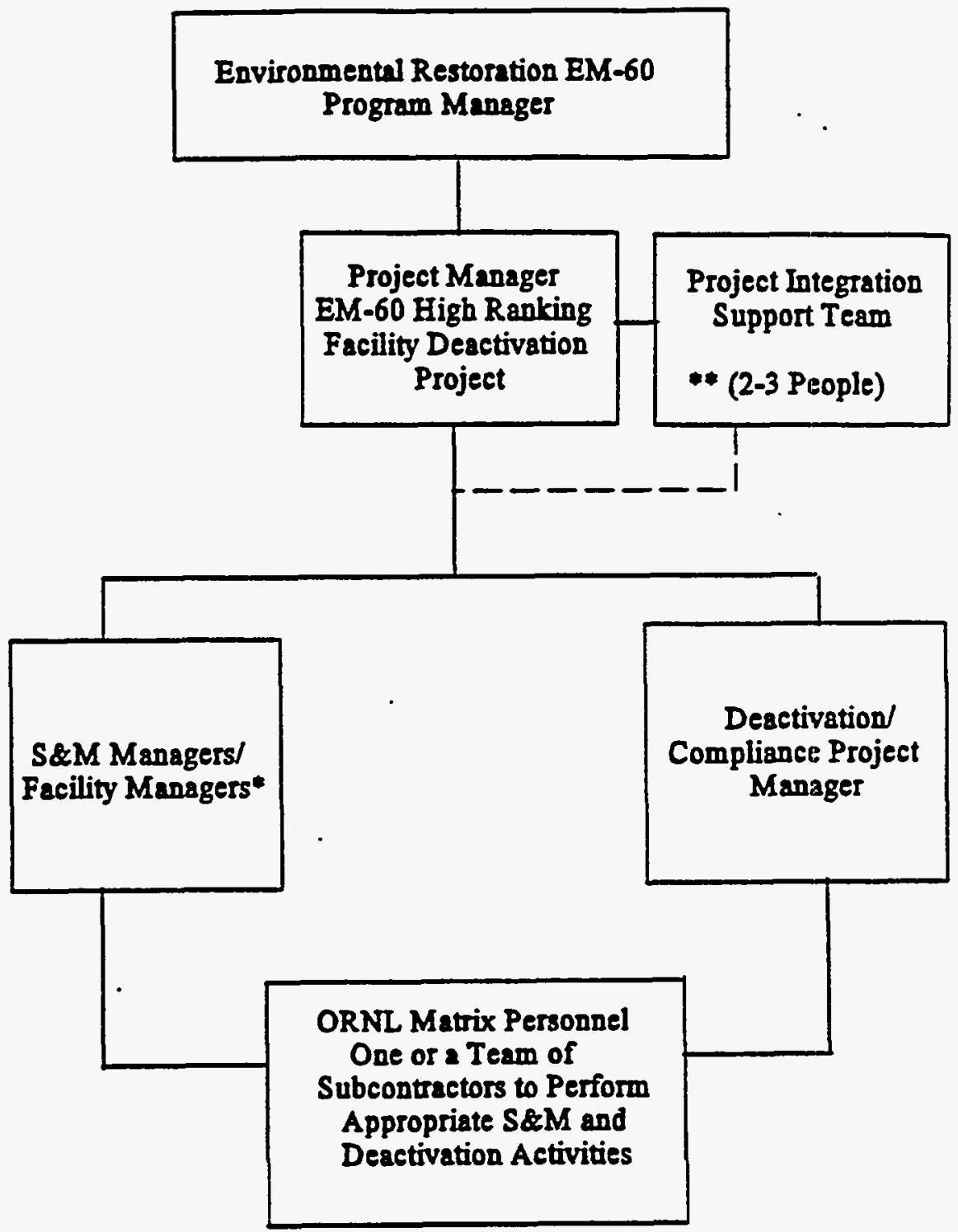

- Will fill dual roles in some cases

- Includes Administrative Support

Fig. 4.1. High Ranking Facilities Deactivation Project-project organization 
Manager can assist the HRFDP Program Manager to meet all of the goals of the client organization (DOE-ORO).

\subsubsection{HRFDP Project Manager}

The ORNL HRFDP Project Manager is responsible for all the project activities and ensuring the project is operated according to all rules and regulations with an ultimate goal to reduce risks to public health and to the environment and to reduce S\&M costs. The project manager is responsible for all deactivation compliance activities, and to turn over all facilities to the EM-40 D\&D program in a timely fashion and as soon as all conditions are met to satisfy transfer. The Project Manager will make all of the day-to-day decisions as to how the project will be conducted (within MOA guidelines). Normal administrative support will be provided to the HRFDP Project Manager, either internally or subcontracted.

The HRFDP Project Manager will also be responsible for integration of the ER Program Central Organization and the appropriate DOE EM-60 Program/Project/Site Managers. The HRFDP Project Manager will act also as a business manager and manage all project activities, including ADS preparation and administration and deactivation cost/benefit analysis and scheduling of activities. All work will be structured more like a business unit with profit and loss responsibilities.

Additional responsibilities will include development of fiscal year work agreements, including development of budgets and prioritizing activities, development of the ADS, funding needs and requirements, prioritizing activities, meeting any and all milestones and reporting monetary variances, and periodic status reports as well as other project activities. The entire program will be directed through and by way of team effort utilizing a time-tested, problem-solving methodology with the project manager as team leader and facilitator. The HRFDP Project Manager will have authority necessary to manage the project effectively and choose any and all personnel transferred or matrixed into HRFDP (in conjunction and agreement with the ER EM-60 Program Manager), both internal and external, who will report directly to the HRFDP Project Manager.

The HRFDP Project Manager is responsible for the following:

- Develop an alternative problem-solving management system utilizing team synergistic effects and cost/benefit analysis to achieve all endpoints.

- Define and administer the technical cost and schedule requirements for the project, including the development and management of the project ADS.

- Assemble key team of Energy Systems and subcontractor personnel. HRFDP will be managed as a team approach to task-based work. The HRFDP Project Manager will have final say in the selection of team members. The team will be composed of competent subcontractors and Energy Systems personnel matrixed or transferred to HRFDP.

- Provide for facility management for all HRFDP facilities. Facility management will include occurrence reporting, safety documentation, maintenance, configuration control, and administrative control of all activities at the appropriate facility manager's facility.

- Identify and recommend S\&M and prioritized deactivation activities based on return of investment and risk reduction and prepare estimates and task duration for activities to meet the HRFDP programmatic objectives in conjunction with the S\&M manager. 
- Assist in planning D\&D activities in these facilities and ensuring the transfer of HRFDP facilities to the EM-40 program in a timely fashion as practical.

- Provide all other direct management and decision making as necessary to ensure both certainties and uncertainties and all associated risks are addressed and managed.

\subsubsection{Project Integration Team (PIT)}

PIT will be composed of the following personnel: an administrative/technical assistant, a technical expert, and one or more engineers. The team will be assigned activities by the HRFDP Project Manager and will address tasks as needed in a multidisciplinary problem-solving environment (see Fig.4.2). The team will be dynamic and interdisciplinary in nature and able to respond to uncertainties and risks and assist the HRFDP Project Manager in successful accomplishment of all activities. The main mission of the team will be to provide options and information upon which the HRFDP Project Manager will base decisions and provide timely assistance as needed to all HRFDP managers. The S\&M manager, deactivation manager, and facility managers, as well as the HRFDP project manager, will comprise the overall team additionally. The function of PIT will include, but not necessarily be limited to, the following.

- Assist the HRFDP Project Manager in planning, coordinating, and prioritizing technical guidance; and budgeting all activities required specifically to accomplish the facility transfer and management (FT\&M) objectives at all HRFDP sites.

- PIT will serve as the focal point for the preparation of fiscal year work agreements as necessary, baselines, and input to the Baseline Environmental Management Report in conjunction with the HRFDP Project Manager's direction. Additionally, it will serve as the focal point for planning and procedures, scheduling, proposals, baseline maintenance, and reporting the on-site FT\&M work to be reported to the ER EM-60 Program Manager, ER Division, and DOE using established reporting structures.

- PIT will ensure consistency in areas such as modeling, risk assessment, applicable or relevant and appropriate requirements, configuration management, data reporting, document control, planning, and conduct of operations.

- The team will also aid in procuring all managers and subcontractors with pertinent information and documents to facilitate and accelerate their respective activities and responsibilities. The focus will be on getting all the necessary buy-offs to getting work initiated and accomplished on time and within budget.

PIT will act as an integral part of the HRFDP team and will play a major role in the success of any and all activities. The majority of PIT will likely be composed of subcontractors. This team method of management will produce a synergistic effect through the open exchange of ideas and the efforts of all team members toward the shared goals of the entire team.

\subsubsection{S\&M Manager}

The S\&M oversight manager/facility manager(s) also will be an integral part of the team. This position is critical in ensuring that all required S\&M activities are accomplished and completed as necessary within the budget developed by the Project Manager in conjunction with DOE. 


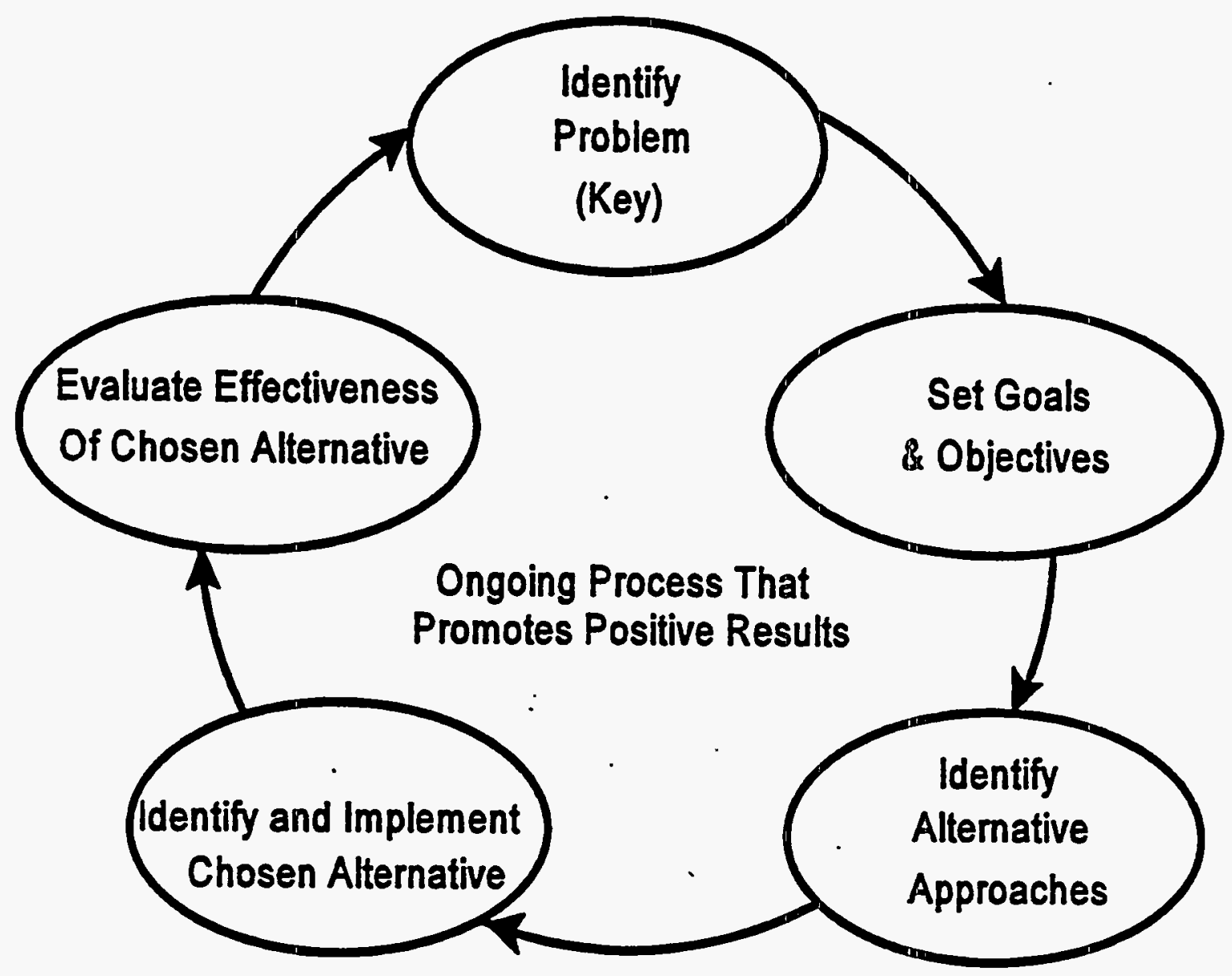

Fig. 4.2. High Ranking Facilities Deactivation Project-problem-solving methodology. 
The S\&M manager(s) will work closely with the HRFDP Project Manager, any facility managers necessary, and PIT as necessary, and will be responsible for completion of all S\&M activities and for developing the final S\&M plan for each facility. Due to the interrelationship between this function and that of a Facility Manager, the S\&M Manager may perform the dual role as Facility Manager, requiring only two persons to act as S\&M Manager and Facility Managers for all buildings. It is envisioned that these individuals will be key individuals and would be capable of assuming the role of facility manager at the reactor facilities.

Therefore, both S\&M managers/facility managers will have to be reactor operators (one backup) as required at TSF due to its status as a stand-by reactor. Building 7602 and 3019B combined will have one facility manager who may also be the S\&M manager, or they may share the role depending on the dynamies and abilities of the individuals involved. The facility manager/S\&M manager will work very closely with the deactivation/compliance manager and the PIT team to ensure work plans are facilitated and assist the team in accomplishing its goals (S\&M and deactivation activities) for less expenditures while ensuring an adequate safety envelope is always maintained. ORNL crafts and trades will be utilized in critical roles and RRD employees will often be necessary to perform reactor shutdown planning and fuel removal work. Subcontractors will be utilized where cost effective.

\subsubsection{Deactivation/Compliance Activities Manager}

The deactivation/compliance activities manager will work closely with PIT and the project manager in formulating creative strategies to ensure the deactivation/compliance activities are accomplished within budget and on time and reduce life cycle S\&M costs and move the program closer to its endpoint. This is a critical position and will possibly be filled by a competent subcontractor or an appropriate employees matrixed to Energy Systems.

\subsubsection{Health Physics Support}

Since primary activities of HRFDP will be S\&M and deactivation, Health Physics support will be necessary to facilitate all work. One or more Energy Systems Health Physics personnel will be matrixed into the project and/or utilized as necessary to support all S\&M and deactivation activities of HRFDP.

\subsubsection{Subcontracting Teams}

Most deactivation work will be contracted out to a subcontractor and/or subcontractor teams. The lead subcontractor of each project will also be part of PIT and as such will actively aid and participate in working out problems and ensuring work is performed on schedule, on time, and within budget. Subcontracts will be task-based with incentives for meeting all of the described task requirements in the time prescribed.

Services of all internal Energy Systems personnel will be procured through agreements negotiated with appropriate ORNL divisions. These working agreements will be task-based at a fixed cost. Any additional costs or activities will require approval by the HRFDP Manager. If negotiated tasks are not performed as agreed, the HRFDP Manager will only authorize payment for activities completed on time. Failure to meet cost and schedule may void the working agreement and stop payments. 


\subsubsection{Initial Startup of Project}

It is expected that a time frame of 3 to 4 months after the initiation of the project will be required to assemble the team of subcontractors and get all required contracts in place. In the interim, all S\&M will be conducted as usual by the personnel currently performing these activities with the exception of some activities that may be reduced or eliminated as determined by the revised S\&M plan. The S\&M plan will be developed by the HRFDP Project Manager based on the information in this document and in concert with identification of drivers for each activity. There will be a brief transition period when the subcontractors will interface with the organizations now performing tasks to properly identify criteria and level of activity. This transition period will ensure an adequate safety envelope is constantly maintained for each facility when subcontractors are utilized.

\subsection{KEY PROJECT ASSUMPTIONS}

A number of key project assumptions have been made in defining the scope of deactivation and in defining the project's estimated costs and schedule. While not all-inclusive, these assumptions are to provide the foundation for the work plan. Therefore, significant changes in assumptions will result in corresponding change in project scope or direction. The assumptions include the following:

- The HRFDP Project Manager and subordinates will have the authority to make field decisions as deemed necessary to get work accomplished within the current system, but always in compliance with appropriate regulations, DOE requirements, and contract agreements.

- Routine S\&M and deactivation activities (excluding fuel removal) will not fall under CERCLA.

- All hazardous materials now located at the transferred facilities will not become RCRA issues.

- Assume asbestos of some type will be present at all facilities. However, asbestos will be removed only when necessary to reduce risk or facilitate other deactivation activities.

- Actual fuel removal will become the responsibility of EM-60 and the HRFDP project manager with the aid of personnel from $R R D$ as deemed necessary.

- Fuel removal schedules developed by RRD will be utilized and followed to the fullest extent possible, practical, and economical.

- The funding for fuel removal and other deactivation activities will be available through a HQ MOA or other source or sources as identified by DOE.

- Project integration costs will continue until the project closeout report is issued.

- "Acts of God" may be subjects of baseline change and will not result in any action that would include punitive actions toward any employee or subcontractor.

- Only those requirements in effect as of October 1,1995 , will be applicable to this project. Additional and/or changed requirements will be subject to a baseline change and may affect life cycle cost and schedule.

- ORNL overhead rate will remain at or near 45 percent.

- No procurement problems or delays from protests will occur.

- Any DOE-requested changes required after a design has been certified for construction will be the basis for a baseline change. 
- Engineering controls will be utilized for contamination control/dust suppression, which will be required during some deactivation activities.

- No delays will be incurred as a result of unforeseen site conditions.

- Adjacent sites and remaining structures will not adversely affect the project.

- Required sampling and analysis efforts will not adversely affect either schedule or cost. Only required sampling will be conducted.

- No project savings have been estimated or expected from the salvage value of materials.

- Plugging and capping penetrations that extend outside of any facility will not require further deactivation actions at any other facility or structure.

- Uranyl nitrate disposition/processing costs have not been included in project cost. Disposal options for Building 7602 will be explored and funding will be requested as necessary.

- Any current building occupants will vacate any used spaces so that the occupants cause no additional burden on EM- 60 .

- Fuel removal will be performed as a CERCLA nontime-critical removal. An Engineering Evaluation and Cost Analysis will be developed as necessary.

- All other activity will be performed as normal S\&M activity and will not require National Environmental Policy Act (NEPA) involvement. All necessary deactivation activity will meet the categorical exclusion clause of NEPA.

- Cost escalation is assumed at $4 \%$ per year.

- The Savannah River Site (SRS) will continue accepting aluminum-clad spent fuel and will accept fuel from BSF and TSF at the time of planned shipment.

- The basket used to hold the TSF reactor fuel in the GE-2000 cast will be approved by the Nuclear Regulatory Commission (NRC) in a timely manner to meet shipment dates, as projected by RRD.

- BSF spent reactor fuel is shipped to SRS in FY 1997 as scheduled and TSR spent reactor fuel will be shipped to SRS in FY 1998 as scheduled (according to RRD schedule). 



\section{SUPPORTING PLANS}

\subsection{SURVEILLANCE AND MAINTENANCE PLAN DEVELOPMENT}

HRFDP will place the facilities in a safe and environmentally sound condition in an economical manner. The S\&M plan will ensure that the facilities are maintained in a safe condition during the post-deactivation surveillance period while awaiting the start of D\&D activities. DOE Order 5820.2A, Radioactive Waste Management, Chap. V, "Decommissioning of Radioactively Contaminated Facilities," requires that an S\&M program be developed and implemented with documented evidence that the checks and inspections are being conducted and the required maintenance is being performed to keep the facility in a safe condition pending the final disposition.

The DOE Policy Memorandum for Acceptance of Facilities for ER Program issued March 15, 1991 , by L. F. Duffy, requires HRFDP facilities to be in a radiologically safe condition following deactivation. The following is the basis for the S\&M plan:

- The S\&M Plan for HRFDP facilities will begin immediately with the transition of these facilities to EM-60.

- The facilities shall be in a physical condition adequate to contain and monitor any radioactive contamination. An "as left" radiation contamination survey of the facilities and surrounding areas will be included in the deactivation records.

- Security systems and procedures shall be adequate to prevent unauthorized entry.

- Special nuclear materials; reactor fuels; and solid and liquid radioactive, hazardous, and mixed waste shall be removed from the facility or the location as soon as practical, and controls shall be documented and approved for those materials for which an end condition cannot be determined. Any exceptions of nuclear and hazardous material remaining in the facility shall be identified and characterized by location, type, and quantity prior to notification to DOE-ORO EM-60.

To meet the S\&M requirements, the HRFDP work plan must ensure that provisions are made to

- ensure reduction of S\&M costs while maintaining and managing risk and providing an adequate safety envelope at all times;

- sustain systems required for monitoring and emission control;

- sustain operation of systems required for protection of surveillance personnel, the general public and environment, and vital equipment;

- sustain systems to respond to emergency conditions expected or likely in the facilities' deactivated state; and

- sustain systems required to prevent structural degradation.

Currently identified S\&M activities for each HRFDP facility are included in Appendix D. The development of detailed deactivation requirements and evaluations of ongoing S\&M activities will result in revisions to the frequencies of performance, need for completion, and scope of each S\&M activity. These enhancements will be incorporated in future revisions to this work plan as necessary. 
This section presents a summary-level description of the expected contents of the plan. The plan will be expanded and detailed as the project proceeds, tasks are identified, and others deleted or reduced in scope as deemed necessary by the S\&M manager in conjunction with the HRFDP Project Manager.

\subsubsection{Deactivated Facility Status}

The facility status expected at the end of the project is described in Sect. 3. The status described is the assumed condition to be used for the final S\&M plan. The status is assumed to allow for minimal life cycle S\&M activities consistent with managing to an acceptable level of remaining risk while still maintaining an adequate safety envelope for the facility before transfer to EM-40.

\subsubsection{Surveillance and Maintenance Costs}

A major objective of HRFDP is to reduce S\&M costs to a minimum during the period between deactivation and D\&D while managing the risk and uncertainty cost for all facilities. Table 5.1 is a conservative estimate of the total $S \& M$ costs based upon currently scheduled $S \& M$ activities through FY 2001. As the detailed postdeactivation S\&M plans are refined, these estimates will be revised. The revised estimates will be reflected in subsequent revisions of this work plan.

Table 5.1. Surveillance and maintenance costs (thousands of dollars)

\begin{tabular}{ccccccc}
\hline Facility & \multicolumn{7}{c}{ Fiscal year } \\
\hline & 1996 & 1997 & 1998 & 1999 & 2000 & 2001 \\
3010 & 1113 & 1158 & 541 & 324 & 227 & 236 \\
3019B & 313 & 245 & 213 & 195 & 165 & 124 \\
7602 & 531 & 372 & 250 & 255 & 260 & 270 \\
7700 & 998 & 1027 & 1069 & 480 & 375 & 390 \\
\hline
\end{tabular}

\subsubsection{Reporting}

Notification and reporting of events will be in accordance with DOE Order 5000.3B, Occurrence Reporting and Processing of Operations Information, as implemented by ORNL facility-specific procedures.

\subsection{SAFETY DOCUMENTATION PLAN}

\subsubsection{Status of Existing Safety Documentation}

All activities in HRFDP facilities are controlled by appropriate safety documentation where necessary. Changes to facility or operations are evaluated by the Unreviewed Safety Question Determination process before being implemented. HRFDP operations are presently governed by the ORNL-approved Safety Analysis Reports (SARs), Safety Assessment (SA), or HSD. The technical safety requirements currently in force were approved by DOE-ORO in 1991. Facilities that do not have technical safety requirements operate under an ORNL-approved LCD. The current technical safety 
requirements or LCDs update the facilities' operational status and identify controls needed for the facilities' limited missions of deactivation activities or storage of excess inventories of radioisotopes and other materials.

As deactivation activities proceed to the point hazards are adequately reduced, SARs and technical safety requirements are retired and replaced with the lower-level safety documentation (HSD and LCD).

Low-risk activities that do not represent significant hazard and are, therefore, not addressed specifically in SARs or SAs are governed by problem safety summaries.

\subsubsection{USQD Determination Process and Status}

The definition and basis for determining the existence of a USQD are contained within DOE Order 5480.21 and implemented at ORNL per procedure ORNL Facility Safety Procedure FS-1.2. All changes to physical or procedural elements within HRFDP facilities may be reviewed to determine what impact, if any, will result from the anticipated change and to ensure that operational restrictions are provided as warranted. The appropriate facility manager will have the authority to make this decision in the field and notify the S\&M manager and HRFDP Project Manager in a timely fashion.

The USQD review process is integrated into all aspects of the organization responsible for design, engineering, maintenance, inspection, operations, and assessment of the facilities and their activities.

The facility technical safety requirements, SARs, LCDs, HSDs, and SAs (as appropriate) provide the "baseline" for procedural and physical elements subject to the USQD process. Any of these elements that are altered to accommodate a project or activity not described in these or other safety analyses, or any changes to the technical safety requirements or LCDs, may require a USQD.

Situations assumed to involve a USQD include

- the probability of occurrence or the consequences of an accident or malfunction of equipment important to safety previously evaluated in a facility safety analysis could be increased,

- the possibility for an accident or malfunction of a different type other than any evaluated previously in the facility safety analyses could be created, and

- that any margin of safety defined in the technical safety requirement/LCD could be reduced.

Changes to facility physical elements, procedural controls, and new project activities or experiments are evaluated by the Facility Manager to determine if the requested change should be subject to the USQD process. The HRFDP Project Manager will make the final decision to any changes.

\subsubsection{Description of Problem Safety (PSS) Summary Report}

PSSs, which are conducted within HRFDP facilities, are prepared for low-risk experiments not specifically discussed in SAR or covered by specific procedures.

The scope and administration of PSSs are described in the Safety Manual for the Radiochemical Technology Section of the Chemical Technology Division. 
Every person (engineer, scientist, technician, and operator) working on a program or experiment within an HRFDP facility is required to have read PSS for that activity. A copy of a PSS is placed in a protective binder and located at the entry/exit to the work area involved.

Appropriate distribution of a PSS is conducted by the Radiochemical Technology Section Document Control Center, where the record copies are retained.

\subsection{QUALITY ASSURANCE}

A Quality Assurance plan for HRFDP will be drafted to be responsive to the requirements of the Quality Program Plan, Y/QD-15, DOE Order 5700.6C, and Title 10 Code of Federal Regulations (CFR) Part 830.120. Implementation of this plan ensures achievement of HRFDP objectives in a safe, reliable, and predictable manner.

To maximize efficiency, the HRFDP QA plan will be based on existing QA plans. The plan will be a working document that requires updating as activity or project needs change.

The QA plan will include requirements for the performance of self-assessments and self-audits that provide assurance to project management that (1) scheduled activities are being performed in accordance with project work plans, schedules, and cost estimates; (2) risks remaining with DOE or Energy Systems are within defined acceptable limits; and (3) an adequate safety envelope is maintained for each HRFDP facility at all times.

The responsibilities and authorities for the QA program are defined in the draft HRFDP Management Plan. The QA program is a management system that reflects management's strategy for accomplishing the objectives of HRFDP.

\subsection{WASTE MANAGEMENT}

Waste generated during HRFDP will be managed in accordance with DOE Orders 5400.1, General Environmental Protection Program; 5400.3, Hazardous and Radioactive Waste Program; and 5820.2A, Radioactive Waste Management, as amended. Waste minimization programs to control waste generation have been established for HRFDP in association with the methods of accomplishment for deactivation activities.

This section describes the handling, treatment, and disposal of project waste and summarizes the techniques that are planned for waste minimization during the project.

Detailed inspections of locations of drains, volumes of anticipated process waste, and routing of disposal lines have not been completed. These inspections should be completed during FY 1996. Any required revisions to this work plan and other project documents will be incorporated following the inspections.

The HRFDP facilities generate two types of nonradioactive wastes: landfill material, such as office or packing trash and personal protection clothing, and hazardous waste. Five types of radioactive waste generated are transuranic (TRU) waste, TRU mixed waste, SLLW, low-level mixed waste, and high-activity waste. High-activity waste must be placed in retrievable storage. In addition, some scrap metal waste will be generated. Some TRU material exists at 7700B and OSSA. 
Landfill materials consist mainly of uncontaminated trash, nonrecyclable waste paper, and other throwaway materials. This waste is transported from ORNL to the sanitary landfill at the Y-12 Plant.

\subsubsection{Waste Minimization}

Waste minimization programs have been implemented in HRFDP facilities. The following are waste minimization objectives for deactivation:

- avoid generating waste by development of work plans for deactivation activities that address waste minimization,

- minimize what is generated,

- recycle what is minimized, and

- treat what cannot be recycled.

These objectives are applied sequentially to all HRFDP work.

Practical waste minimization efforts include eliminating characteristic hazardous waste, segregating wastes into compactible categories, compacting solid waste, and concentrating diluted waste. Key project waste minimization activities are described in the following sections.

\subsection{NATIONAL ENVIRONMENTAL POLICY ACT DOCUMENTATION}

The basis for this document is that all activities in this project will be completed under the existing categorical exclusion CX 2147X. This is the categorical exclusion negotiated by DOE-ORO for activities meeting these exclusions of full NEPA at ORNL. Therefore, no additional NEPA documentation is needed for the successful completion of this project.

\subsection{ENVIRONMENT, SAFETY, AND HEALTH}

ORNL ER Program policy is to provide a safe and healthful workplace for all employees, subcontractors, DOE prime contractors, and visitors, and to protect the environment. The accomplishment of this policy at ORNL is guided by the Health and Safety Plan for the Environmental Restoration Program at Oak Ridge National Laboratory, ORNL/ER-226.

The ORNL ER Program health and safety plan follows the format recommended by EPA for remedial investigation and feasibility studies, as well as 29 CFR 1910.120 and DOE EM-40 guidelines for preparing documentation for performing tasks on hazardous waste sites, treatment, storage, and disposal facilities, and for responding to emergencies on hazardous waste sites. The health and safety plan is also applicable to activities that are not considered to be performed on the Hazardous Waste Operations and Emergency Response sites.

Activities sponsored by the ORNL ER Program may consist of, but are not limited to, remedial action; construction; S\&M; D\&D; environmental sampling; environmental radiological surveys; well installation; well plugging and abandonment; geophysical surveys and mapping; technology development and testing; underground storage tank sampling, removal, or closure; liquid transfer from process holding tanks; and off-site activities. 
Site-specific health and safety plans (SSHASPs) will be prepared on a project-specific basis as necessary to address in greater detail the hazards and controls associated with major particular tasks. SSHASP shall address all site-specific information including, but not limited to, the following: work site location; description of each task; work plan for accomplishing each task; anticipated hazards to health and safety; prescribed methods for controlling hazards; monitoring requirements; personal protective equipment requirements; sanitation, decontamination, training, and medical requirements; and emergency information.

SSHASPs shall be developed for ORNL ER projects involving major activities on sites that fall under the Hazardous Waste Operations and Emergency Response Program (HAZWOPER). An SSHASP or an approved (by ER ES\&H Manager) equivalent document shall also be required for other activities that do not fall under the requirements of the HAZWOPER Program but present hazardous or unsafe conditions for workers or the environment.

\subsection{DOCUMENTATION AND RECORDS}

Data forms, logbooks, and certificates of analysis form part of the documentation pool required for providing objective evidence of quality. All documentation must be legible, retrievable, and in such a format as to be defensible in the ability to accurately reconstruct the performance of work.

Documentation and related objective evidence of quality shall consist of

- the work plan,

- the QA plan,

- the health and safety plan (when required),

- facility surveillance logbooks,

- facility maintenance and calibration logbooks,

- facility logbooks (to be maintained by the Facility Manager or designated representative),

- facility operating procedures, and

- personnel training files.

All documentation must be completed in waterproof black ink, and corrections must be marked through with a single line, dated, and initialed. Handwritten documents must be legible. The information to be provided for each of these documents is described in ESP-102, "Field Quality Control."

\subsubsection{Field Documentation Forms}

Field investigation activities will be documented primarily on field documentation forms. The forms referenced in the procedures (provided in Appendix A) will be used during this investigation. Any information pertinent to the current field activity or field condition that is not requested on the field documentation form should be entered in the "Comments" section of the form and in the field logbook. The forms used at the site will be numbered sequentially. 
All completed field documentation forms will be transferred to a hard cover, three-ring notebook for temporary storage upon completion. In addition, any charts, oversized pages, and other printed material (e.g., lists of sample times) pertinent to current field activities will be securely attached to the corresponding field documentation form and contained in the notebook. The number of the corresponding field documentation form must be written somewhere on the attached material and contained in the notebook.

\subsubsection{Quality Records}

The completed forms will periodically be taken from the notebook and entered into the project's data-management database. As appropriate during the life of the project, completed field forms and related quality-affecting documentation will be copied periodically and transferred to the Camp. Dresser, and McGhee Federal Programs Corporation in Oak Ridge, Tennessee, in accordance with dual-storage requirements for quality records.

Quality records will be authenticated as such by project management in consultation with the project QA coordinator. Quality records will include project documentation such as logbooks, field forms, and calibration records, as identified by this QA project plan. All records generated on this project are subject to the requirements of ESS-QA-17.0, "Quality Assurance Records." 


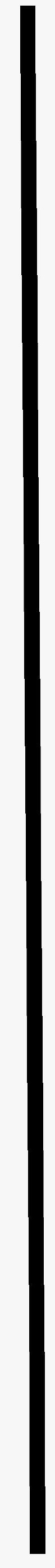




\section{REFERENCES}

BNI (Bechtel National), and Energy Systems (Martin Marietta Energy Systems, Inc.). 1982. "ORNL Observational Approach Workshop on Inactive LLLW Tanks," presented in October 1992 at Oak Ridge National Laboratory, Oak Ridge, Tennessee.

EPA (U.S. Environmental Protection Agency), Office of Underground Storage Tanks. 1990. Standard Test Procedures for Evaluating Leak Detection Methods: Automatic Tank Gauging Systems. EPA/530/UST-90/006, Midwest Research Institute, Falls Church, Virginia.

EPA, DOE (U.S. Department of Energy), and TDEC (Tennessee Department of Environment and Conservation). 1992. Federal Facility Agreement for the Oak Ridge Reservation. DOE/OR-1014, MMES, Oak Ridge, Tennessee.

Fleagle, R. G., and J. A. Businger. 1980. An Introduction to Atmospheric Physics, Academic Press, Orlando, Florida.

Energy Systems and Vista Research. 1995. Detailed Leak Test Plan and Schedule for Oak Ridge National Laboratory Liquid Low-Level Waste Active Tanks. DOE/OR/01-1129\&D2, Oak Ridge, Tennessee. 
Appendix A

\section{DESCRIPTION AND HISTORY OF FACILITIES}




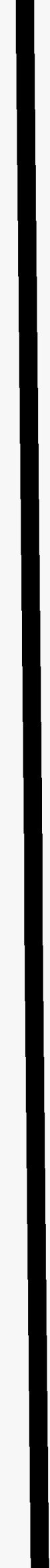




\section{CONTENTS}

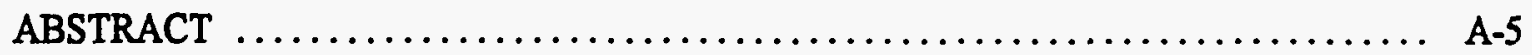

A.1. SITE DESCRIPTION $\ldots \ldots \ldots \ldots \ldots \ldots \ldots \ldots \ldots \ldots \ldots \ldots \ldots \ldots \ldots \ldots \ldots \ldots \ldots \ldots \ldots \ldots$

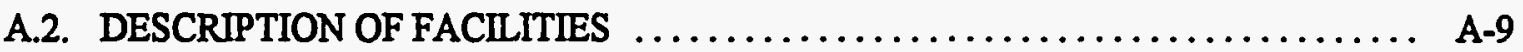

A.2.1. BUILDING 7700-TOWER SHIELDING FACILITY $\ldots \ldots \ldots \ldots \ldots \ldots$ A-9

A.2.1.1. Description ............................. A-9

A.2.1.2. Facility History $\ldots \ldots \ldots \ldots \ldots \ldots \ldots \ldots \ldots \ldots \ldots \ldots \ldots$ A-14

A.2.1.3. General Status ............................ A-15

A.2.2 BUILDING 3019B-HIGH RADIATION LEVEL ANALYTICAL

FACIITY ................................... A-20

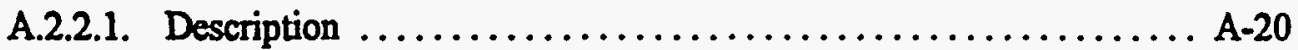

A.2.2.2. Facility History $\ldots \ldots \ldots \ldots \ldots \ldots \ldots \ldots \ldots \ldots \ldots \ldots \ldots \ldots$ A-20

A.2.2.3. General Status ......................... A-22

A.2.3 BUILDING 7602-INTEGRATED PROCESS DEMONSTRATION

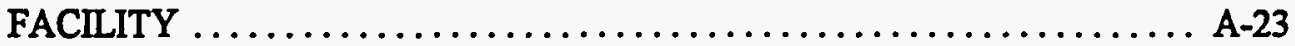

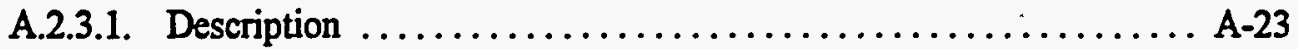

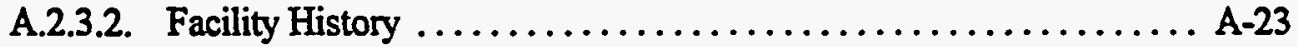

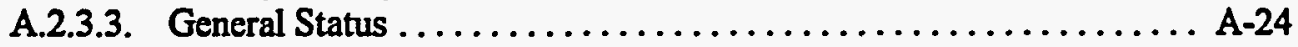

A.2.4 BUILDING 3010-BULK SHIELDING REACTOR FACILITY ......... A-26

A.2.4.1. Description ............................

A.2.4.2. Facility History $\ldots \ldots \ldots \ldots \ldots \ldots \ldots \ldots \ldots \ldots \ldots \ldots \ldots \ldots \ldots \ldots \ldots \ldots$

A.2.4.3. General Status ............................ A

\section{TABLES}

A.1. Radioactive sources at the Tower Shielding Facility $\ldots \ldots \ldots \ldots \ldots \ldots \ldots \ldots \ldots$ A-16

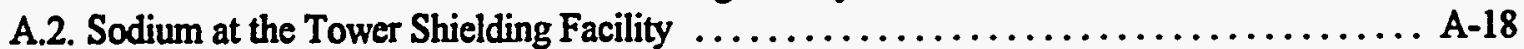

A.3. Lithium hydride at the Tower Shielding Facility $\ldots \ldots \ldots \ldots \ldots \ldots \ldots \ldots \ldots \ldots \ldots$

A.4. Hazardous materials at the Tower Shielding Facility (excluding $\mathrm{Na}$ and $\mathrm{LiH}$ ) ....... A-19

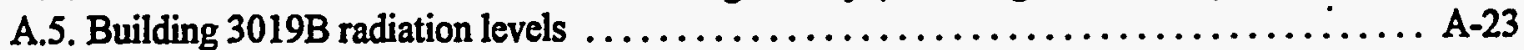

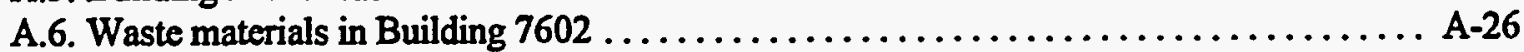

\section{FIGURES}

A.1. Facilities located on the Main Oak Ridge National Laboratory complex

(Bldgs. 7602 and Tower Shielding Facility not on map) ................. A-8

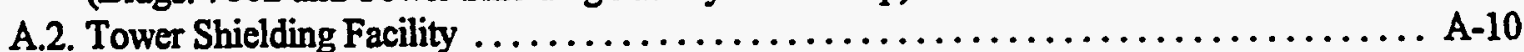

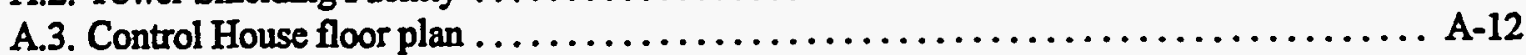

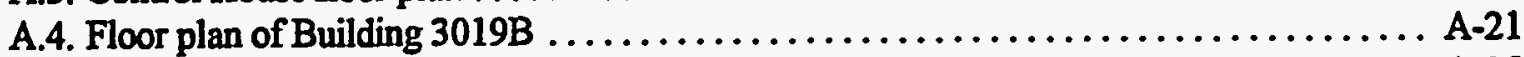

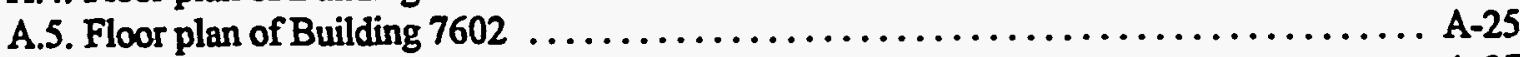

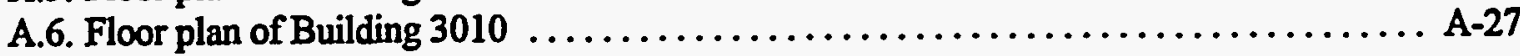




\begin{abstract}
This appendix presents information about the high-risk facilities at ORNL that are to be (1) maintained in a safe condition under the existing maintenance and surveillance plan and (2) prepared for acceptance and transfer into the Nuclear Material and Facility Stabilization Program (EM-60) and ultimately transferred to the Decontamination and Decommissioning Program (D\&D).

The site and the supporting Oak Ridge National Laboratory operational services that interface with the facilities are described briefly in Sect. A.1. A description and brief history of each of the individual facilities included in the High Ranking Facilities Deactivation Program (HRFDP) is presented in Sect. A.2.
\end{abstract}




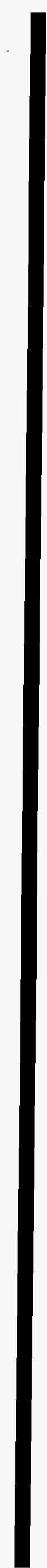




\section{A.1. SITE DESCRIPTION}

Two of the facilities in the High Ranking Facility Deactivation Project (HRFDP), Buildings 3019B and 3010, are located at the central Oak Ridge National Laboratory (ORNL) complex in Bethel Valley. ORNL and the two remaining facilities, 7700 and 7602, are located on the U.S. Department of Energy (DOE) Oak Ridge Reservation approximately $13 \mathrm{~km}$ (8 miles) from the population center of the city of Oak Ridge. The locations of the facilities within ORNL are shown in Fig. A.1.

The Oak Ridge Reservation lies in an area between two mountain ranges. The Cumberland Mountains rise to $910 \mathrm{~m}$ ( $3000 \mathrm{ft}$ ) or more $16 \mathrm{~km}$ (10 miles) northwest, while $113 \mathrm{~km}$ (70 miles) to the southeast the Great Smoky Mountains reach an altitude of some $2010 \mathrm{~m}$ ( $6600 \mathrm{ft}$ ). The area is part of the Valley and Ridge physiographic province. The reservation is a wooded complex dominated by a series of ridges and valleys tending northeast/southeast. It is bounded on three sides by the Clinch River, which is a tributary of the Tennessee River and is part of the water system controlled by the Tennessee Valley Authority.

The mountains on the east and the Cumberland Plateau on the west have a protecting and moderating influence on the region's climate. As a result, it is milder than the more continental climates found just to the west on the Plateau or on the eastern side of the Smoky Mountains. The prevailing winds follow the general topographic trend of the ridges: daytime, up-valley winds come from the southwest; nighttime, down-valley winds come from the northeast. The Smoky Mountains to the southeast provide general sheltering; severe storms such as tornadoes or high-velocity windstorms are rare. Similarly, the mountains divert hot, southerly winds that develop along the southern Atlantic coast. The average monthly temperature ranges from about $3.5^{\circ} \mathrm{C}\left(38^{\circ} \mathrm{F}\right)$ in winter to $25^{\circ} \mathrm{C}\left(77^{\circ} \mathrm{F}\right)$ in summer. The 38-year annual average precipitation (water equivalent) is $1.36 \mathrm{~m}$ (53.5 in.), including approximately $0.25 \mathrm{~m}$ (9.8 in.) of snowfall, with monthly precipitation peaking in January and February.

The population (1980 census) of the city of Oak Ridge is 28,000 . Except for the city of Oak Ridge, the land near the Oak Ridge Reservation is predominantly rural, used largely for residences, small farms, and cattle pasture. Knoxville, the major metropolitan area nearest Oak Ridge, is located about $40 \mathrm{~km}$ (25 miles) to the east and has a population of approximately 183,000 .

The central ORNL site is located in Bethel Valley between Chestnut Ridge on the north and Haw Ridge. Although the valley floor is highly developed within the central site area, the surrounding terrain is wooded. White Oak Creek passes to the south of the developed area and leaves the valley through a gap in Haw Ridge into Melton Valley. Experimental programs that require isolation are located at satellite sites in Melton Valley. 


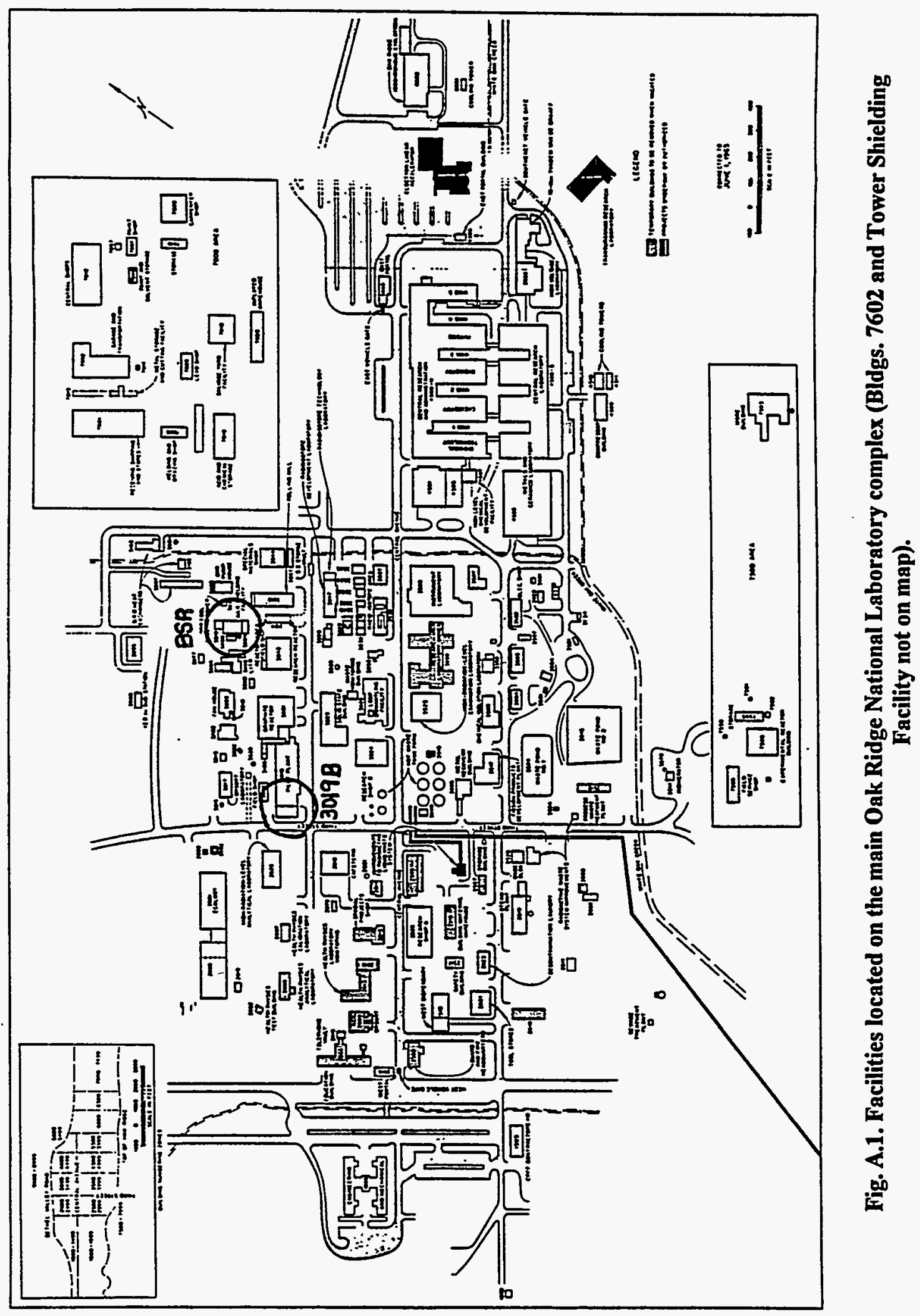




\section{A.2. DESCRIPTION OF FACILITIES}

\section{A.2.1 BUILDING 7700—TOWER SHIELDING FACILITY}

\section{A.2.1.1 Description}

The Tower Shielding Facility (TSF) was built at ORNL in 1953 to enable studies of asymmetric shield configurations for the Aircraft Nuclear Propulsion Project. Operations began in 1954. This research required that the reactor radiation source be located in a region free from ground or structure scattering. Four reactors have been used at the TSF. These include the TSR-I, TSR-II, Aircraft Shield Test Reactor (ASTR), and the Space Nuclear Auxiliary Power (SNAP) reactor. The TSF is located 2.35 miles south-southeast of the main ORNL complex. The facility is situated on a hill with an elevation of $1069 \mathrm{ft}$. Access to the site is provided by two roads, one leading northeast to the Health Physics Research Reactor (HPRR), and one leading west to Highway 95. A map of the TSF is shown in Figure A.2.

The Department of Energy (DOE) has identified the TSF as a high risk ranking facility primarily because of the spent fuel loaded in the reactor and the high cost of surveillance and maintenance (S\&M). The other major concern at the facility is the presence of more than 55 tons of sodium $(\mathrm{Na})$ and more than 3 tons of lithium hydride ( $\mathrm{LiH}$ ) at the site. An old cemetery and a cave are also situated near the TSF site.

The tower structure is a braced and guyed steel frame forming a $100-\mathrm{ft} \times 200-\mathrm{ft} \mathrm{rectangle,} \mathrm{with} \mathrm{a} \mathrm{leg}$ placed at each of the four comers. Each leg is $9 \mathrm{ft}$ square and $315 \mathrm{ft}$ high, and terminates at the lower end in an inverted truncated pyramid. Since the objective of the design was to minimize the scattering of radiation by structural material, the unit weight of the steel in the tower structure was kept below $400 \mathrm{lb} / \mathrm{ft}$. The towers were equipped with hoists capable of lifting loads of up to 55 tons to heights of $200 \mathrm{ft}$. By lifting the reactor and shielding materials to these heights, the shielding characteristics of the materials could be measured without interference from radiation reflected off the ground. Prior to its shutdown, the TSF was the foremost research facility in the world dedicated to the study of radiation shielding.

Maintenance access to the towers is provided by a bridge between legs I and IV of the north tower at the 100-ft level; the bridge is reached by an elevator in leg IV. In 1963, the design calculations of the towers and the reactor support structure were reviewed and found to be in conformity with the "Specifications for the Design, Fabrication, and Erection of Structural Steel for Buildings" of the American Institute of Steel Construction for all operating conditions.

A pair of galvanized plow-steel cables (or sister guys) 2 in. in diameter stretch between leg I of the north tower and leg II of the south tower, and another pair stretches between leg IV of the north tower and leg III of the south tower. Each cable of the pair was designed to be held in 40,000-1b tension by two similarly constructed pairs of guys that extend from the top of the towers to ground anchors in the north-south direction. The towers are guryed in the east-west direction by eight inclined gury cables. Each cable was originally set at a tension of $76,000 \mathrm{lbs}$ and makes an angle of $32^{\circ}$ with the towers.

Twelve ancillary facilities provided support to the Building 7700 tower structure. These facilities and areas are scheduled for transfer to EM-60 along with Building 7700 . 


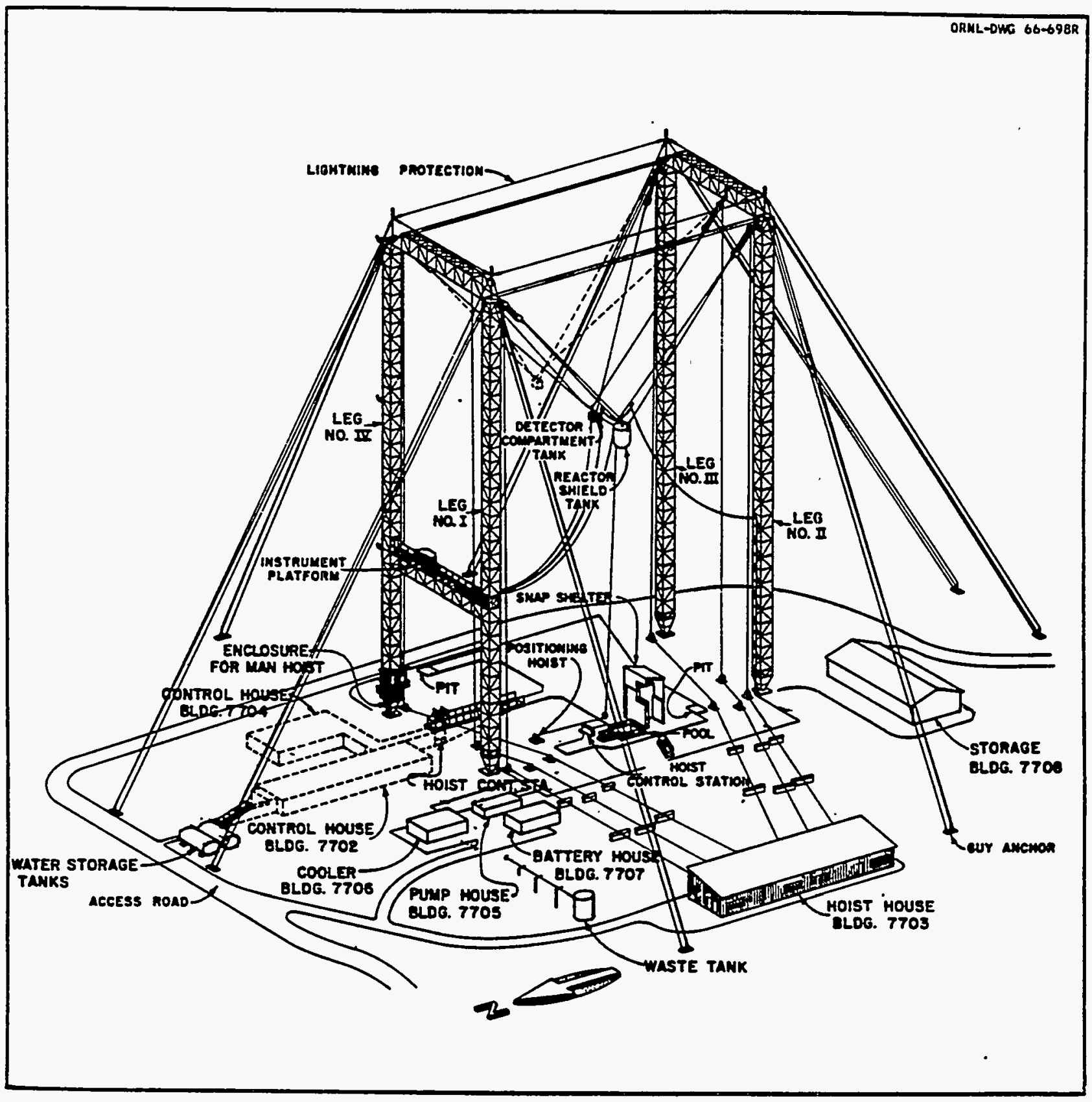

Fig. A.2. Tower Shielding Facility. 


\section{A.2.1.1.1 Building 7700A-Big Beam Shield (Reactor)}

The TSR-II reactor is housed in the center of the Big Beam Shield. The Big Beam Shield is located between the two western tower legs. The shield occupies an area of $196 \mathrm{ft}^{2}$ and has a height of $10 \mathrm{ft}$. The structure is constructed of deep reinforced concrete. The TSR-II fuel remains loaded in the reactor. No nonradiological hazardous materials are contained in the structure. The amount of radioactive contamination in $7700 \mathrm{~A}$ is uncertain.

The TSR-II core consists of 60-mil-thick, curved aluminum-clad uranium/aluminum alloy plates cooled and moderated by water. The fuel plates are shaped so that the assembled core is a spherical fuel ammulus from which radiation symmetrically emits. The neutron-absorbing shim safety control plates for the reactor are contained in the control ball, a fuel-free region centered inside the fuel annulus. Outside the fixel annulus is a reflector region, which may contain aluminum-water, lead-boral-aluminum, or other combinations of materials as experiments demand.

The three regions of the TSR-II core-the internal reflector, the fuel annulus, and the other reflectorare located in the lower section of a cylindrical aluminum tank with a hemispherical bottom inside the Big Beam Shield (7700A). This aluminum tank is $8 \mathrm{ft}$ long. The inside diameter of the tank at the hemispherical end is 37 in., which increases to 40 in. at the open end to facilitate removal of fuel elements, shielding, etc., from the tank.

\section{A.2.1.1.2. Building 7700B—Outside source storage area (OSSA)}

OSSA is an underground site used to store radioactive sources. The sources are stored in eight stainless steel pipes with 2-in. diameters. These pipes are buried $5 \mathrm{ft}$ beneath the ground. A total of 9 grams of transuranic material is stored in $7700 \mathrm{~B}$. This transuranic material consists primarily of americium-241 $\left({ }^{41} \mathrm{Am}\right)$ and plutonium-239 $\left({ }^{29} \mathrm{Pu}\right)$. No radioactive contamination or hazardous materials are located in the 7700B-OSSA.

\section{A.2.1.1.3 Building 7701-TSF pool}

The TSF handling pool is located midway between the two west tower legs. The pool was used to provide shielding during the removal of fuel elements and changing reactor shields. The pool is divided into two sections. The main section has a $20 \mathrm{ft} \times 20 \mathrm{ft}$ area and a depth of $25 \mathrm{ft}$. The smaller section has a $12 \mathrm{ft}$ length, $4 \mathrm{ft}$ width, and a $22 \mathrm{ft}$ depth. Currently, the pool is drained and covered by a large concrete slab. No hazardous materials are stored in the pool, and the pool is not believed to contain radioactive contamination.

\section{A.2.1.1.4 Building 7702-Control House}

Building 7702 is an underground reinforced concrete bunker just to the north of the towers. The interior dimensions are $115 \mathrm{ft} \times 30 \mathrm{ft} \times 10 \mathrm{ft}$. To shield operating personnel from radiation while the reactor was operating, the building has an 18-in. concrete roof covered by $3.5 \mathrm{ft}$ of earth. To ensure that radioactive, airborne particulates could not enter the building, blowers forced the incoming air through a high-efficiency particulate air (HEPA) filter and activated charcoal filters, and the building was maintained at a slight positive pressure to prevent air from leaking into the building. The building houses the reactor controls, a data collecting facility, a counting room, and offices. The floor plan of the Control House is shown in Fig. A.3. 


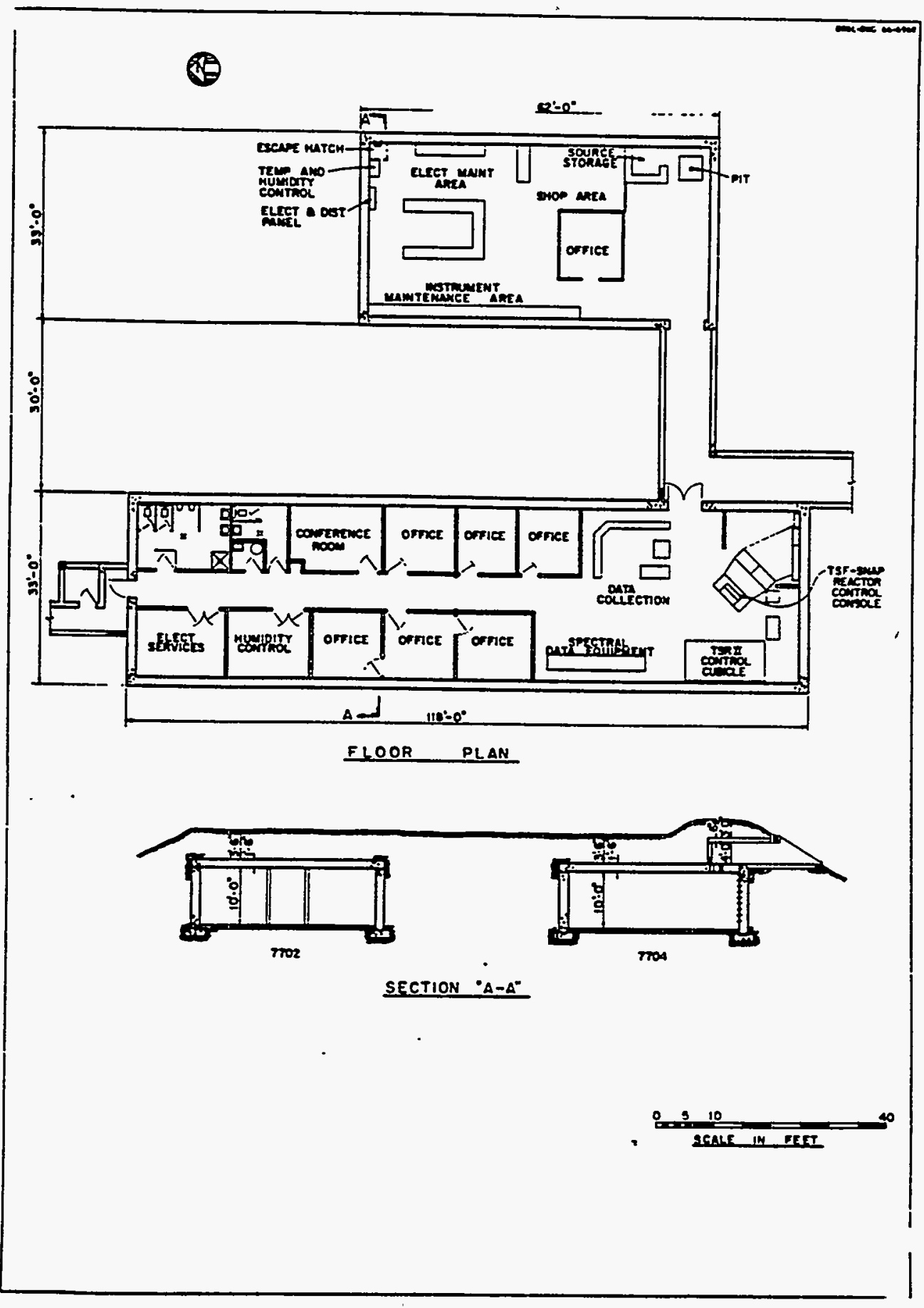

Fig. A.3. Control House floor plan. 
Building 7702 is not believed to contain any radioactive contamination, although radioactive calibration sources are stored in a safe located in the hallway between Buildings 7702 and 7704 . Hazardous materials present include polychlorinated biphenyls (PCBs), chlorofluorocarbons (CFCs), asbestos, and elemental lithium, as well as volatile organic compounds and flammable material.

\section{A.2.1.1.5 Building 7703-Hoist House}

The Hoist House, Building 7703, sits to the west of the TSF towers. It is a one-story, $5236 \mathrm{ft}^{2}$ steel frame building. No radiological material was ever used or stored in this building. The only hazardous materials currently stored in the building are several cans of over-the-counter pesticides. Building 7703 houses the drums and motors used to lift and position the reactor and shields. These hoists will be needed to remove the fuel, so they must be maintained in working condition. There are six major hoists. The first pair of hoists, which were used to lift the reactor, are capable of lifting 55 tons to a height of $200 \mathrm{ft}$. The second pair is able to lift a load of 40 tons to a height of $200 \mathrm{ft}$, while the third pair of hoists can lift 30 tons. The controls to the hoist are not located in Building 7703. The two hoist control stations are located at the south entrance to Building 7702 and by the reactor handling pool. No portions of this building are contaminated, and no radioactive material has ever been brought into the building. The only hazardous substances stored in the building are cans of commercial wasp spray and potentially hazardous used motor oil.

\section{A.2.1.1.6 Building 7704-Control House 2}

Control House 2 is an underground reinforced concrete bunker to the east of Building 7702. It has interior dimensions of $59 \mathrm{ft} \times 30 \mathrm{ft} \times 10 \mathrm{ft}$. An 8-ft wide walkway connects it to the larger control house, Building 7702. There is no normal entrance to Building 7704 except through the walkway to Building 7702, although there is an escape hatch in the northwest corner that can be used in an emergency. Building 7704 shares the ventilation system of Building 7702. An 18-in. concrete roof covered by $3.5 \mathrm{ft}$ of earth protected workers from radiation while the reactor was operating. Control House 2 was used primarily as a service and shop area. Radioactive calibration sources are present in a safe in the hallway between Buildings 7702 and 7704, but no areas of radioactive contamination have been found. Hazardous materials present include PCBs, CFCs, $5700 \mathrm{lbs}$ of lead bricks, and volatile organic compounds. Asbestos is assumed to be present in all facilities.

\section{A.2.1.1.7. Building 7705-Pumphouse}

Building 7705, the TSF Pumphouse, is a $663 \mathrm{ft}^{2}$ reinforced concrete facility. This facility is used to circulate reactor cooling water. The building contains pumps, piping, filters, a demineralizer, and a level control tank. No measurable external contamination has been found in the facility. The resin in the demineralizer and the interior of the pipes may contain some radioactive contamination and will require further characterization at some point. The only hazardous substance present is the silica in the demineralizer.

\section{A.2.1.1.8 Building 7706-Cooler}

The TSF heat exchanger is housed in Building 7706. The building is a $600 \mathrm{ft}^{2}$ steel framed structure. No external radioactive contamination has been detected, although some activated minerals in the cooling water may have scaled onto the interior of the piping. Hazardous materials at the cooler are limited to asbestos insulation on the pipes and lubricants. 


\section{A.2.1.1.9 Building 7707-Battery House}

Building 7707 is a $375 \mathrm{ft}^{2}$ concrete/masonry structure that houses rectifiers and lead acid batteries that can provide emergency backup power for the TSF. The building contains no radioactive contamination. The lead acid batteries are the only potentially hazardous materials in the building.

\section{A.2.1.1.10 Building 7708-shielding storage facility (Butler Building)}

The TSF Shielding Storage Facility is a $3444 \mathrm{ft}^{2}$ steel frame building. The building is used to store miscellaneous material and equipment, with the large sodium and $\mathrm{LiH}$ shields occupying the majority of the space. Other hazardous substances present, in addition to the sodium and $\mathrm{LiH}$, include PCBs, asbestos, and volatile organic compounds. The building is in reasonably good condition, although there are some leaks in the roof. Less than $10 \%$ of the building is posted as rad areas.

The TSF Boneyard/Scrapyard is an outdoor scrapyard with an area of approximately $20,000 \mathrm{ft}^{2}$. Items in the boneyard include six control balls from the reactor sitting in an open tank, and many other metal items that were activated by the neutron flux from the reactor. Most of the boneyard will require cleanup while potentially recycling the steel and iron scrap. A tank remover exists at the TSF site. The tank remover was used to move tanks during armored vehicle shielding experiments in the early 1960s. The tank remover is not known to be contaminated and contains large amounts of potentially useful scrap metal.

\section{A.2.1.1.11. Building 7716-Filter Pumphouse main pool}

The Filter Pumphouse is a $100 \mathrm{ft}^{2}$ steel frame and reinforced concrete building. It houses the pump and filters required to maintain the quality of the demineralized water in the 7701 handling pool. The facility is currently shut down because the handling pool has been drained. This facility contains no hazardous materials or radioactive contamination. This facility will be needed to remove the fuel.

\section{A.2.1.1.12 Civil Defense facility}

The Civil Defense facility is an underground bunker built into the side of a hill. It was used in the early 1960 s to study the levels of protection such structures could provide from the radiation from nuclear weapons. Nothing is stored in this bunker, and radiation surveys have discovered no contamination in the interior, although some activated reinforced concrete shielding blocks are located just outside the bunker.

\section{A.2.1.2 Facility history}

The original Tower Shielding Reactor (TSR-1) was a box-shaped, 500-kW Materials Test Reactor (MTR)-type reactor that operated from 1954 to 1960. During this period, the reactor was used in experiments for the Aircraft Nuclear Propulsion (ANP) Project. The ANP Project was sponsored by the Atomic Energy Commission (AEC), the Department of Defense, the National Advisory Committee for Aeronautics, Pratt and Whitney, and Atomics International. During 1956, the TSR-I was also used in the J-57 Engine Exposure Project, sponsored by AEC and Pratt and Whitney. The TSR-I fuel has since been reprocessed.

The spherically symmetric TSR-II replaced the TSR-I in 1960. The TSR-II has been operated at powers levels up to $100 \mathrm{~kW}$ and for a variety of experiments, both at ground level and at elevated positions. The TSR-II instrumentation system was first used to operate the reactor at the Tower 
Shielding Facility on March 30, 1960. After several months of critical experiments, the reactor was disassembled for modifications. After reassembly, the reactor was first operated with full cooling water flow on December 22, 1960. On February 6, 1961, it was operated at a maximum authorized power of $100 \mathrm{~kW}$, and it has been in operation at various powers up to $100 \mathrm{~kW}$ since that time. The TSR-II reactor was shut down on October 1,1992 . There are $8.4 \mathrm{~kg}$ of TSR-II fuel remaining at the TSF site.

During its 32 years of operation, the TSR-II reactor has been utilized for a variety of shielding experiments. From 1960 to 1968, the TSR-II was used for nuclear weapons shielding experiments sponsored by AEC, the Defense Atomic Support Agency, and the Naval Radiological Defense Laboratory. In 1961, AEC, the United Kingdom, Ordnance Tank Automotive Command, Army Tank Automotive Center, and General Dynamics performed armored vehicle shielding experiments with the TSR-II. Missile silo shielding tests sponsored by AEC, Civil Defense Agency, and Defense Atomic Support Agency were performed from 1961 to 1962. From 1971 to 1974, AEC and Westinghouse conducted experiments with the TSR-II for the Liquid Metal Fast Breeder Reactor Program. The Energy Research and Development Administration (ERDA) performed experiments for the Clinch River Breeder Reactor Program from 1974 to 1977. DOE's nuclear energy division carried out experiments for the Gas-Cooled Fast Reactor Program from 1977 to 1980, for the High-Temperature Gas-Cooled Reactor from 1983 to 1984, and for the Alternate Shielding Materials Experiment in 1985. The final program using the TSR-II reactor was the Japanese-American Shielding Program of Experimental Research Program. This program was sponsored by the DOE Office of Nuclear Energy (DOE-NE), the Nuclear Fuel Development Corporation, and the Japanese. This program was conducted from 1986 to 1992.

From 1958 to 1959, the Aircraft Shield Test Reactor (ASTR), an MTR-type reactor used for shielding research in an operating aircraft, was under test at the TSF. This program was sponsored by AEC and Convair. The ASTR was operated at a power level of $1 \mathrm{MW}$. After completion of its mission, the ASTR fuel was returned to Convair.

The Space Nuclear Auxiliary Power (SNAP) reactor was installed in 1967 to be used for shielding studies in conjunction with the TSR-II. This program was sponsored by AEC and Atomics International. The TSF-SNAP reactor was approved for power levels up to $10 \mathrm{~kW}$. The SNAP reactor ceased operation in 1971. In 1973, the SNAP reactor and its fuel were sent to Y-12.

\section{A.2.1.3 General status}

The physical conditions of the TSF facilities are generally good. Because the TSR-II fuel has remained loaded in the reactor core, it has been necessary to keep most of the reactor's systems operational. Radioactive decays in the fuel are no longer generating enough thermal energy to require forced cooling. Nevertheless, the cooling water circulation system has been maintained and still operates so that the quality of the water in the reactor can be controlled. This is necessary to maintain the electrical resistivity of the water and prevent corrosion of reactor parts.

Some repairs will be required before the facility can be deactivated. The 7701 handling pool will be needed to provide shielding during fuel removal operations. The handling pool is currently drained and covered. The pool will need to be thoroughly cleaned, inspected, and filled before it can support the fuel removal operations. One of the hoists in Building 7703 is broken. The broken hoist will be needed to lift the reactor and place it in the 7701 pool; therefore, the hoist must be repaired before the fuel can be removed. The roof in the 7708 Butler building has some leaks. These leaks represent no immediate threat but could pose a problem if any of the sodium or $\mathrm{LiH}$ shields began to leak. 


\section{A.2.1.3.1 Inventories}

In addition to the facilities themselves, responsibility for the materials stored at the TSF will also transfer to EM-60 in October 1995. These materials include both radioactive substances and potential hazardous (RCRA and/or Toxic Substances Control Act) materials.

\section{A.2.1.3.2 Spent fuel}

The fuel at the TSF remains loaded in the TSR-II reactor core, which is housed in the center of the 7700A Big Beam Shield. The fuel is composed of a uranium/aluminum alloy, clad in aluminum. The spent fuel has a mass of $8.4 \mathrm{~kg}$, with a ${ }^{25} \mathrm{U}$ enrichment of 93 percent. The fuel is approximately 35 years old. The reactor has not operated since September 1992, so many of the short-lived fission products have had time to decay to trace levels. Besides the fuel loaded in the TSR-II core, four lune plates are stored in a concrete silo next to the Big Beam Shield. These lune plates contain 233 grams of ${ }^{235} U$.

\section{A.2.1.3.3 Radioactive sources}

Nine grams of transuranic material, composed mostly of ${ }^{241} \mathrm{Am}$ and ${ }^{239 \mathrm{Pu}}$, are stored in the underground 7700B-OSSA area. These sources are stored in 2-in.-diam stainless steel pipes buried $5 \mathrm{ft}$ below the surface.

A fission chamber and smaller sources used for calibrations are stored in a safe in the hallway between Buildings 7702 and 7704 . The composition, activity, and locations of these sources are presented in Table A.1.

Table A.1. Radioactive sources at the Tower Shielding Facility

\begin{tabular}{|c|c|c|}
\hline Isotopes & Activity & Location \\
\hline Americium-Beryllium & $1.9 \mathrm{Ci}$ & $7700 \mathrm{~A}$ \\
\hline Americium-Beryllium & $3.04 \mathrm{Ci}$ & $7700 \mathrm{~B}$ \\
\hline Americium-Beryllium & $2.86 \mathrm{Ci}$ & $7700 \mathrm{~B}$ \\
\hline Americium-Beryllium & $6.03 \times 10^{6}$ neutrons/second & $7700 \mathrm{~B}$ \\
\hline Cobalt-60 & $65.3 \mu \mathrm{Ci}$ & $7702 / 7704$ \\
\hline Cobalt-60 & $65 \mu \mathrm{Ci}$ & $7702 / 7704$ \\
\hline Cesium-137 & $1.8 \mathrm{Ci}$ & $7702 / 7704$ \\
\hline Plutonium-Beryllium & $6.28 \times 10^{5}$ neutrons/second & $7700 \mathrm{~B}$ \\
\hline
\end{tabular}

\section{A.2.1.3.4 Depleted uranium}

Depleted uranium is being stored inside six sodium shielding blocks and one $\mathrm{LiH}$ shielding block. All six of the sodium shielding blocks are housed inside the Building 7708 butler building, while the $\mathrm{LiH}$ 


\section{A-17}

shield is stored outside, south of the TSF pad. The mass and characterization of the depleted uranium in these blocks have not been determined.

\section{A.2.1.3.5 Hazardous materials}

Of the nonradiological hazardous materials being stored at the TSF, the large sodium and LiH shielding blocks cause the greatest concern. If the shielding blocks were to leak, the sodium and $\mathrm{LiH}$ could represent serious fire hazards because these materials react violently with water. Other hazardous materials do not represent an immediate danger but will need to be removed in most cases before the facilities can be turned over to EM-40.

\section{A.2.1.3.6 Sodium}

There are 45 shielding blocks containing approximately 55 tons of sodium stored at the TSF. Most of these are housed in the 7708 butler building. However, the four largest blocks, containing 80 percent of the sodium, are located outdoors. Eighteen shielding blocks, holding 19 tons of sodium, contain no radioactive contamination. Eleven shields contain 33 tons of sodium contaminated with sodium-22 $\left({ }^{2} \mathrm{Na}\right)$. The half life of ${ }^{2} \mathrm{Na}$ is $2 \frac{1}{2}$ years. The activity levels of the contaminated sodium are on the order of $10^{-3} \mathrm{~Bq} / \mathrm{cm}^{3}$. The remaining 16 shields are in activated cans and contain 2 tons of sodium. A final six shields contain sodium and depleted uranium. The contents of shields containing uranium have not yet been characterized. The shapes, conditions, contents, and locations of the sodium shields are summarized in Table A.2.

\section{A.2.1.3.7 Lithium hydride}

Nine aluminum shields containing 6 tons of $\mathrm{LiH}$ are stored in the Building 7708 butler building. Seven of these shields, holding 5 tons of the $\mathrm{LiH}$, contain no radioactive contamination. The aluminum shields of the remaining two shielding blocks have been activated. The I ton of $\mathrm{LiH}$ inside these two blocks may be contaminated with tritium. One final $\mathrm{LiH}$ shielding block located outside the 7708 butler building contains depleted uranium. This shielding block has not yet been characterized. The shapes, conditions, contents, and locations of the LiH shields are summarized in Table A.3.

\section{A.2.1.3.8 Other hazardous materials}

Most of the other hazardous materials at the TSF are stored outdoors. The lithium is stored in the 7702 control house, and 5700 lbs of lead bricks are stored in the 7704 control house. Most of the rest of the materials are stored on the south side of the perimeter road, near the 7708 butler building and leg III of the tower structure. The quantities and storage mode of hazardous substances other than the sodium and $\mathrm{LiH}$ are summarized in Table A.4. 
Table A.2. Sodium at the Tower Shielding Facility

\begin{tabular}{|c|c|c|c|c|c|}
\hline Shields & Dimensions & Condition & Location & Na volume & Mass \\
\hline 1 & $11^{\prime} \mathrm{OD} \times 5^{\prime}$ & Clean & Outdoors & $475.2 \mathrm{ft}^{3}$ & $13052 \mathrm{~kg}$ \\
\hline 4 & $5^{\prime} \times 5^{\prime} \times 1^{\prime}$ & Clean & Building 7708 & $100 \mathrm{ft}^{3}$ & $2747 \mathrm{~kg}$ \\
\hline 3 & $18^{n} \times 18^{n} \times 1^{\prime}$ & Clean & Building 7708 & $6.8 \mathrm{ft}^{3}$ & $187 \mathrm{~kg}$ \\
\hline 1 & $4^{\prime} \times 4^{\prime} \times 3^{\prime}$ & Clean & Outdoors & $48.0 \mathrm{ft}^{3}$ & $1318 \mathrm{~kg}$ \\
\hline 1 & $4^{\prime \prime} \mathrm{OD} \times 2^{\prime}$ & Clean & Building 7708 & $0.2 \mathrm{ft}^{3}$ & $6 \mathrm{~kg}$ \\
\hline 3 & $6^{n} \mathrm{OD} \times 27^{n}$ & Clean & Building 7708 & $1.3 \mathrm{ft}^{3}$ & $36 \mathrm{~kg}$ \\
\hline 2 & $6^{\prime \prime O D} \times 2^{\prime}$ & Clean & Building 7708 & $0.8 \mathrm{ft}^{3}$ & $22 \mathrm{~kg}$ \\
\hline 1 & $6^{\prime \prime} \mathrm{OD} \times 7^{\prime \prime}$ & Clean & Building 7708 & $0.1 \mathrm{ft}^{3}$ & $3 \mathrm{~kg}$ \\
\hline 1 & $11^{\prime}$ OD $\times 5^{\prime}$ & Activated & Outdoors & $475.2 \mathrm{ft}^{3}$ & $13052 \mathrm{~kg}$ \\
\hline 2 & $11^{\prime} \mathrm{OD} \times 2.5^{\prime}$ & Activated & Outdoors & $475.2 \mathrm{f}^{3}$ & $13052 \mathrm{~kg}$ \\
\hline 5 & $5^{\prime} \times 5^{\prime} \times 1^{\prime}$ & Activated & Building 7708 & $125.0 \mathrm{ft}^{3}$ & $3433 \mathrm{~kg}$ \\
\hline 1 & $5^{\prime} \times 5^{\prime} \times 6^{\prime \prime}$ & Activated & Building 7708 & $12.5 \mathrm{ft}^{3}$ & $343 \mathrm{~kg}$ \\
\hline 2 & $5^{\prime} \times 5^{\prime} \times 3^{n}$ & Activated & Building 7708 & $12.5 \mathrm{ft}^{3}$ & $343 \mathrm{~kg}$ \\
\hline 1 & $5^{\prime} \times 5^{\prime} \times 1^{\prime}$ & Activated can & Building 7708 & $25.0 \mathrm{ft}^{3}$ & $687 \mathrm{~kg}$ \\
\hline 2 & $5^{\prime} \times 5^{\prime} \times 6^{n}$ & Activated can & Building 7708 & $25.0 \mathrm{ft}^{3}$ & $687 \mathrm{~kg}$ \\
\hline 1 & $1^{\prime} O D \times 4^{\prime}$ & Activated can & Building 7708 & $3.1 \mathrm{ft}^{3}$ & $85 \mathrm{~kg}$ \\
\hline 2 & $5^{\prime} \times 5^{\prime} \times 4^{n}$ & Activated can & Building 7708 & $16.7 \mathrm{ft}^{3}$ & $459 \mathrm{~kg}$ \\
\hline 2 & $6^{\prime \prime} \mathrm{OD} \times 1^{\prime}$ & Activated can & Building 7708 & $0.4 \mathrm{ft}^{3}$ & $11 \mathrm{~kg}$ \\
\hline 1 & $6^{\prime \prime} \mathrm{OD} \times 27^{n}$ & Activated can & Building 7708 & $0.4 \mathrm{ft}^{3}$ & $11 \mathrm{~kg}$ \\
\hline 1 & $5^{n} \mathrm{OD} \times 7^{n}$ & Activated can & Building 7708 & $0.1 \mathrm{ft}^{3}$ & $3 \mathrm{~kg}$ \\
\hline 6 & $2^{n} \mathrm{OD} \times 30^{n}$ & Activated can & Building 7708 & $0.3 \mathrm{ft}^{3}$ & $8 \mathrm{~kg}$ \\
\hline 2 & $6^{n} \mathrm{OD} \times 28^{n}$ & Contains $U$ & Building 7708 & Unknown & Unknown \\
\hline 1 & $6^{n} \mathrm{OD} \times 23^{n}$ & Contains U & Building 7708 & Unknown & Unknown \\
\hline 3 & $5^{\prime} \times 5^{\prime} \times 18^{\prime \prime}$ & Contains $U$ & Building 7708 & Unknown & Unknown \\
\hline
\end{tabular}




\section{A-19}

Table A.3. Lithium hydride at the Tower Shielding Facility

\begin{tabular}{|r|c|c|c|c|c|}
\hline Shields & Dimensions & Condition & Location & LiH volume & Mass \\
\hline 2 & $5^{\prime} \times 5^{\prime} \times 1^{\prime}$ & Clean & Building 7708 & $50 \mathrm{f}^{3}$ & $1161 \mathrm{~kg}$ \\
\hline 2 & $5^{\prime} \times 5^{\prime} \times 3^{\prime \prime}$ & Clean & Building 7708 & $12.5 \mathrm{ft}^{3}$ & $290 \mathrm{~kg}$ \\
\hline 1 & $5^{\prime} \times 5^{\prime} \times 6^{\prime \prime}$ & Clean & Building 7708 & $12.5 \mathrm{ft}^{3}$ & $290 \mathrm{~kg}$ \\
\hline 2 & $25^{\prime \prime}$ OD $\times 4^{\prime \prime}$ & Clean & Building 7708 & $2.3 \mathrm{ft}^{3}$ & $53 \mathrm{~kg}$ \\
\hline 1 & $10^{\prime \prime}$ OD $\times 2^{\prime \prime}$ & Activated can & Building 7708 & $1.0 \mathrm{ft}^{3}$ & $23 \mathrm{~kg}$ \\
\hline 1 & $3^{\prime}$ OD $\times 3^{\prime}$ & Activated can & Building 7708 & $21.2 \mathrm{f}^{3}$ & $492 \mathrm{~kg}$ \\
\hline 1 & Ellipsoidal & Contains U & Outdoors & Unknown & Unknown \\
\hline
\end{tabular}

Table A.4 . Hazardous materials at the Tower Shielding Facility (excluding Na and LiH)

\begin{tabular}{|c|c|c|}
\hline Material & Quantity & Mode of Storage \\
\hline Asbestos & Undetermined & Pipe Insulation \\
\hline Copper & 1.1 Tons & Slabs \\
\hline Lead & 100 Tons & Slabs, Bricks, Shot, Shapes \\
\hline Hevimet & 2.6 Tons & Slab \\
\hline Bismuth & 1.0 Tons & Slabs \\
\hline Boron Carbide & 6 Tons & Shields \\
\hline Boral & $500 \mathrm{lbs}$ & Sheet \\
\hline Zirconium & $880 \mathrm{lbs}$ & Slab \\
\hline Lithium & $1.53 \mathrm{lbs}$ & In 3 Metal Containers \\
\hline Thorium Oxide & 8.8 Tons & In Shields \\
\hline Cadmium & $500 \mathrm{lbs}$ & In Shields \\
\hline
\end{tabular}

\section{A.2.2 BUILDING 3019B-HIGH RADIATION LEVEL ANALYTICAL FACILITY}

\section{A.2.2.1 Description}

Building 3019B is the High Radiation Level Analytical Facility (HRLAF). The building is attached to Buildings 3019A and 3135. Building 3019B is accessed from and shares a wall and some utilities 
with Building 3019A. Building 3019B shares a wall, but no utilities with Building 3135 . Building 3135 was a guard shack for the complex, but is now being used only for storage and is not known to be contaminated Buildings 3019A, 3019B, and 3135 are part of the Radiochemical Development Facility (RDF), otherwise referred to as the Building 3019 Complex. All three buildings are located inside the ORNL security area on the northern end of Third Avenue where it intersects with Hillside Avenue. Building 3019B is currently inactive and unoccupied except for S\&M activities.

HRLAF (3019B) is a 3,000- $\mathrm{ft}^{3}$ concrete and masonry block building containing a hot cell bank with seven cells, equipped with master-slave manipulators, and a central storage cell from and to which materials were transferred for storage. The floor plan of Building 3019B is shown in Fig. A.4. On the west end of the building is a loading dock that appears as a small appendage with red doors to the outside. This dock was used to load and unload carriers to and from the charging area. The dock was cleaned out in 1990 and has been used within the last five years to transport materials from the building. The cells are also serviced by a rear access area providing entry to the back of the cells.

Ventilation is provided by the 3019 laboratory off-gas ventilation system. This system maintains a continuous flow of air from the office areas to the hot cells and out of the building via roughing and HEPA filters to the permitted 3020 stack. This ventilation system is essential to maintaining the safety envelope of the building because it ensures that negative pressure is maintained. A breach in the ventilation exhaust header could result in the release of alpha contamination throughout Buildings 3019A and 3019B.

\section{A.2.2.2 Facility history}

Building 3019B was constructed in 1952 and was operating until its mission ended in 1984. HRLAF was used for separating, processing, and analyzing highly radioactive samples from many ORNL programs, including all those operated in Building 3019A. The samples handled in Building 3019B included fission products, activation products, uranium, plutonium, and other transuranic materials.

From 1954 to 1958, the analytical facilities of Building 3019B were used in support of the Thorium Extraction (THOREX) Program.

From 1958 to 1960, the analytical capabilities of the HRLAF supported many programs from several ORNL divisions. These included the development of the Plutonium Uranium Extraction (PUREX) Process for the separation of plutonium from spent fuel, and the development of the Materials Testing Reactor (MTR) at ORNL.

From 1960 through 1964, Building 3019B was used for analytical support in the Volatility Program.

From 1960 through 1964, the Kilorod Program was supported by Building 3019B analytical capabilities. 


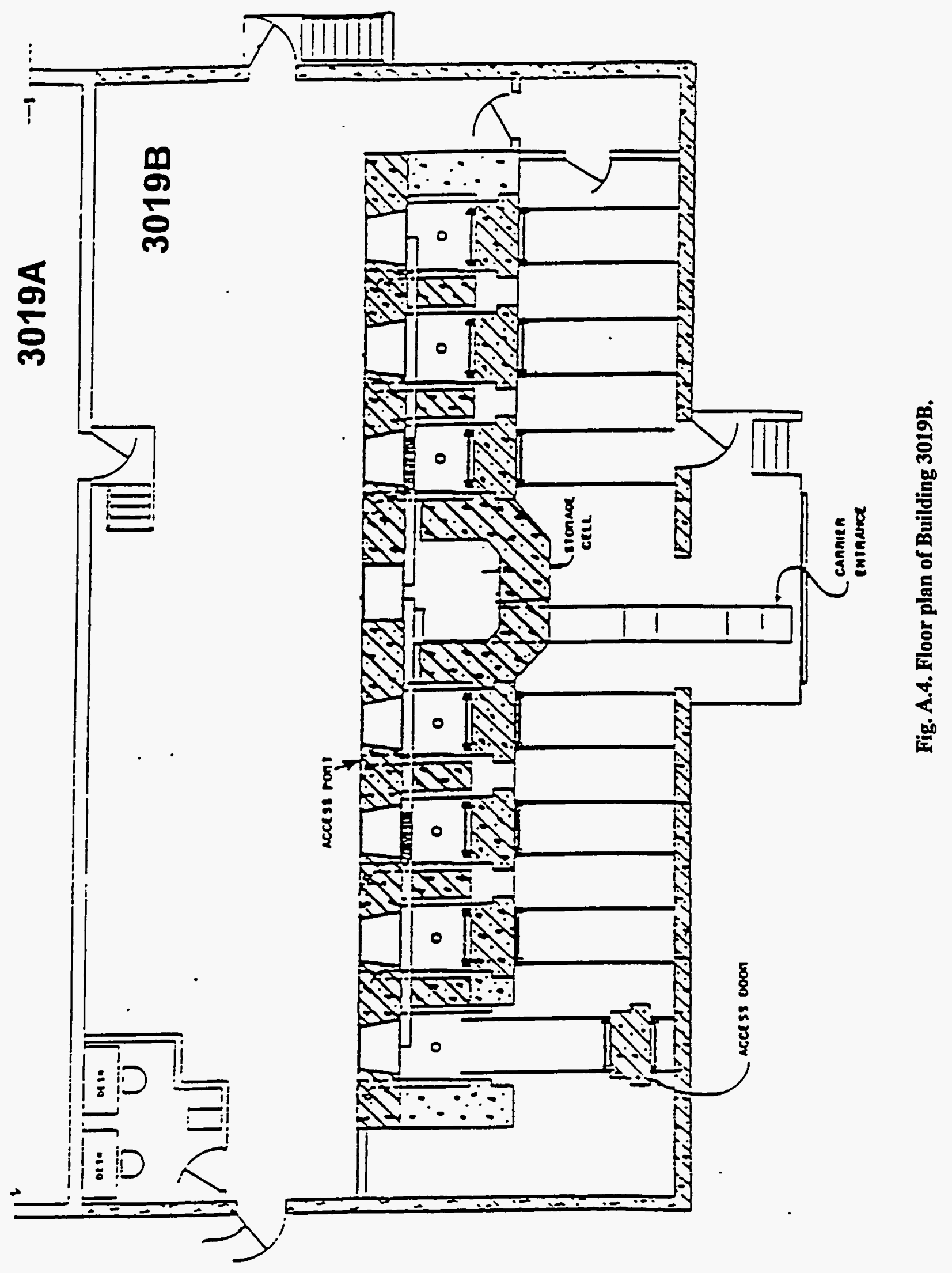


The last program supported by the analytical facility in Building 3019B was the Light Water Breeder Reactor (LWBR) Program, which was conducted between 1969 and 1976.

After the mission of Building 3019B ended in 1980, some improvements were made to ensure the safety envelope remained intact and to decrease the surveillance required. The exhaust duct, which is part of the ventilation system so vital to the safety envelope, was replaced in the mid-1980s. In FY 1994, all equipment in the cells was transferred to a Solid Waste Storage Area (SWSA), leaving the work tables and any debris that may have been under the work tables in place. The viewing windows of all except one of the cells were drained of their zinc bromide shielding liquid, and a lead shield was placed over each window after the zinc bromide was drained. The middle cell window never contained zinc bromide because it was made of lead glass. The lead glass still remains in place. All waste materials and transferrable contamination were removed from the operation room (Room 15), and the face of the cells, the walls, and the floor were bonded to cover the fixed contamination.

\section{A.2.2.3 General status}

The facility has become degraded significantly in the years following its retirement from service. The vinyl lining of the cells' interior is spalling and allowing contamination to pervade the concrete block walls.

The exterior of the hot cell exhaust ventilation header shows signs of deterioration. Because negative ventilation is required to maintain a safety envelope, some attention to the hot cell exhaust is warranted. An inspection of the interior of the ventilation would clarify whether the deterioration extends completely through the header and whether patching or complete replacement is needed.

The hot cell drain system was purposefully shut down because the collection tank to which the drains run is breached, and the integrity of the lines leading from the drains to the collection tank is suspect. Should leakage into the hot cells occur, the water could pick up and carry contamination under the door and outside the building, causing environmental insult. The Building 3019B roof leaks because settling since the construction of the building has caused some portions of the roof to sag such that the roof drains are no longer in recessed areas. Some of the leaks are over the hot cells area, and the water from the roof leaks has been traced to the outside of the cell walls. Whether the water has penetrated the cells themselves is unknown.

\section{A.2.2.3.1 Inventories}

The current inventory of nuclear material in Building 3019B consists of radiological contamination in and around the cells. The area within the cells is grossly contaminated with both beta-gamma and alpha-emitting radioisotopes, but the amount of contamination is unknown because no radiological surveys of the cells have been completed. Table A.5 summarizes the radiation levels detected during surveys of room 14, the cell access area, in Building 3019B. Funding for 3019B has been very difficult to obtain in past years; therefore, little was done to reduce risks.

Some RCRA material is probably present in the hot cells; however, the area is too highly radioactive to test. The materials listed below may have been used in the construction of the hot cells, or they may have migrated to the hot cells from some other part of 3019A or 3019B:

- residual lead oxide powder from the use of the lead shielding,

- mercury from mercury vapor lamps used inside the hot cells, 
- PCB from light ballasts, and

- asbestos in insulation.

Table A.5. Building 3019B radiation levels

\begin{tabular}{|c|c|c|c|c|}
\hline Area & Subarea & $\begin{array}{c}\text { Highest } \alpha \\
\text { radiation level } \\
\left(\mathbf{d p m} / 100 \mathbf{c m}^{2}\right)\end{array}$ & $\begin{array}{c}\text { Highest } \beta / \gamma \\
\text { radiation level } \\
\left(\mathbf{d p m} / 100 \mathrm{~cm}^{2}\right)\end{array}$ & $\begin{array}{c}\text { Survey } \\
\text { date }\end{array}$ \\
\hline Above cells & N/A & 950 & 90,000 & $2 / 17 / 94$ \\
\hline Behind cells & $\begin{array}{c}\text { Back cell } \\
\text { walls }\end{array}$ & 111,000 & Not measured & $2 / 13 / 94$ \\
\hline Behind cells & Floor & 20 & 1,522 & $5 / 1 / 95$ \\
\hline $\begin{array}{c}6 \text { shielded carriers } \\
\text { behind cells }\end{array}$ & Carrier No. 3 & 35 & 2,200 & $5 / 5 / 94$ \\
\hline $\begin{array}{c}6 \text { shielded carriers } \\
\text { behind cells }\end{array}$ & Carrier No. 5 & 20 & 6,300 & $5 / 5 / 94$ \\
\hline
\end{tabular}

\section{A.2.3 BUILDING 7602-INTEGRATED PROCESS DEMONSTRATION FACILITY}

\section{A.2.3.1 Description}

Building 7602 is the Integrated Process Demonstration Facility. The building is attached to Building 7603, the Remote Operations and Maintenance Demonstration Facility, which is active. The two buildings are separated only by a block wall, which does not extend completely to the ceiling of the high bay area. The floor plan of Building 7602 is shown in Fig. A.5.

Building 7602 is a $15,841 \mathrm{ft}^{2}$ concrete block and steel frame building. The building has three floors. Three pits that could collect any liquids coming from leaks are included as part of building 7602 . Those pits are the F14 pit, the solvent extraction pit, and the dissolver pit. The F14 pit is on the mezzanine level of the building and contains tanks for collecting any liquid flowing from drains. The solvent extraction pit was once used for special equipment tests, and extends downward from the main floor to the basement level. The dissolver pit is the largest feature in the building and is visible just at the left of the building entrance on the main floor.

An additional pit is being used for storage of waste that originated at Building 7602 . This pit is next to the domed reactor building (Building 7600) and has a sloped enclosure roof. The pit was originally intended as a reactor cell but was never used for that purpose. Some encapsulated dummy fuel pins originating from Building 7602 are being stored there.

Building 7602 is currently inactive and unoccupied except for S\&M activities. The building is currently owned by the Robotics and Process Systems Division (RPSD) and funded by the NE. 


\section{A.2.3.2 Facility history}

Building 7602 was constructed in 1963 as a reactor fueling building for the Experimental Gas-Cooled Reactor, which was never fueled or operated. Because the reactor was never fueled, no fuel was ever handled in Building 7602.

The building was idle until 1974, when the original Liquid Metal Fast Breeder Reactor Fuel Cycle Program moved into the Building 7602 offices. The sponsor of the program was AEC. Until approximately 1981, the building was used as part of that program, which developed technology and equipment to reprocess fuel in connection with the Clinch River Breeder Reactor. During those 5 years, the program name was changed to the Consolidated Fuel Reprocessing Program, and subsequently to RPSD.

From 1981 through 1983, Building 7602 additions, modifications, and process/remote equipment installation were accomplished via a $\$ 16 \mathrm{M}$ line item project sponsored by DOE-NE in preparation for a collaborative program with Japan in fuel reprocessing technology. Half of the funding for this program was supplied by Japan. The collaborative program involved separations process development and testing, and was conducted from 1984 through 1994. The principle technology employed was PUREX with centrifugal contactors, which used depleted and natural uranium. Building 7602 was declared surplus effective September 30, 1994, and consequently declared a High Risk Ranking Facility by the DOE.

\section{A.2.3.3 General status}

Building 7602 is currently shut down and deactivated. When the roof was patched in early 1995 , the P\&E craftsman determined that the older sections of the roof needed replacement. Funding has been obtained from NE to replace the old sections of the Building 7602 roof, and this action is scheduled for completion prior to transfer of the facility to EM-60 on October 1, 1995. Although the facility is considered surplus, the following systems continue to be in operation for its maintenance:

The fire protection system, which includes sprinkler systems and related sensors and alarms, is operational. This provides protection against fire damage that could cause an environmental release of contamination.

The heating system is in operation because it is necessary to prevent the sprinkler system (part of the fire protection system) from freezing and bursting during the winter. The cooling water headers are also protected by the building heating system. The cooling water headers pass through Building 7602 to service other buildings in the complex. Because the heating system uses the same steam boiler to heat Buildings 7601, 7602, and 7603, there is no substantial achievement of cost savings in eliminating the need for heating Building 7603.

The facility ventilation system and related alarms are in operation. This system maintains continuous flow of air from Building 7603 through Building 7602 to a high-efficiency particulate air (HEPA) filter bank in an enclosure on the Building 7602 roof, from which the air is discharged to a permitted stack. The alarm at the supervisory alarm panel would indicate low ventilation flow. This ventilation flow is an important component of the safety envelope around Building 7602 because it ensures unidirectional air flow into the facility such that all airborne contamination is carried to the filter bank and not released into the environment. Over the past year, sampling with continuous air monitors has confirmed that dried surface contamination is being released inside Building 7602 as particulate matter. 
The sump high level alarms on the F14 pit, the solvent extraction pit, and the dissolver pit are operational because the pits are the low points in Building 7602 that collect any liquid that might come from leaks. The high level alarms at the supervisory alarm panel would indicate leaks from the roof, the cooling water headers, or other sources.

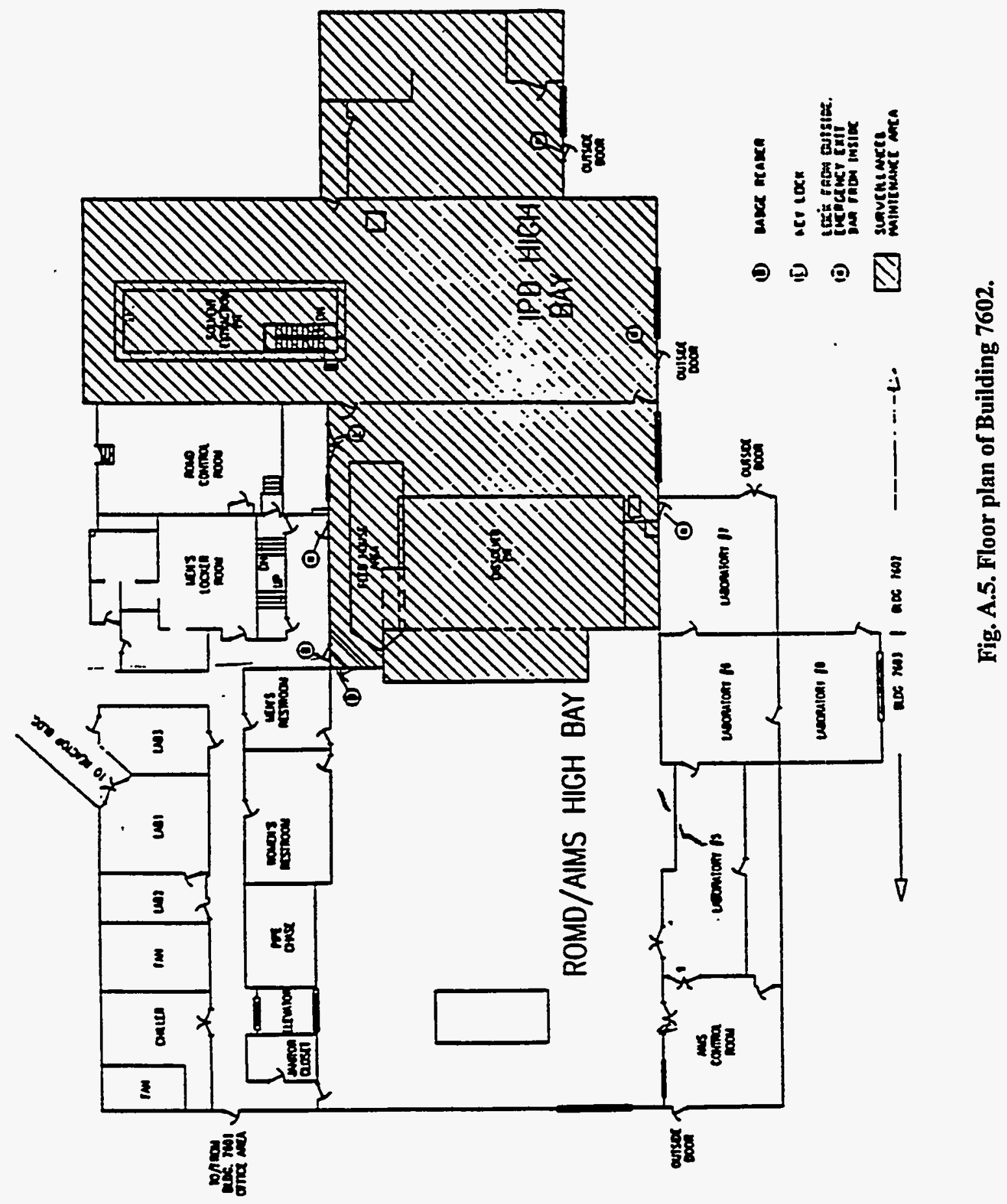


Since Building 7602 was declared surplus, process chemicals and uranium have been removed from the process systems, and all have been disposed of except 2,774 gal of concentrated uranyl nitrate solution.

The process tanks have been flushed, and the resulting chemicals and uranium are currently being transferred to dispositioning organizations.

\section{A.2.3.3.1. Inventories}

No special nuclear materials, other transuranics, or irradiated material/spent fuel are present in the building. Table A.6 summarizes the inventory of radioactive waste materials remaining in Building 7602 .

Table A.6. Waste materials in Building 7602

\begin{tabular}{|l|l|c|c|}
\hline \multicolumn{1}{|c|}{ Waste material } & \multicolumn{1}{|c|}{ Location } & $\begin{array}{c}\text { Inventory } \\
\text { (gal) }\end{array}$ & $\begin{array}{c}\text { U inventory } \\
\text { (kg) }\end{array}$ \\
\hline Concentrated uranyl nitrate solution & Inside building & 2,774 & 4,400 \\
\hline Uranium contamination & $\begin{array}{l}\text { On surfaces and inside } \\
\text { process equipment }\end{array}$ & N/A & 10 \\
\hline $\begin{array}{l}\text { Encapsulated dummy fuel pins and } \\
\text { assemblies }\end{array}$ & $\begin{array}{l}\text { Storage pit adjacent to } \\
\text { domed reactor building }\end{array}$ & N/A & 1,697 \\
\hline
\end{tabular}

\section{A.2.4 BUILDING 3010-BULK SHIELDING REACTOR FACILITY}

\section{A.2.4.1 Description}

The Bulk Shielding Facility (BSF), which houses the Bulk Shielding Reactor (BSR) and the Pool Critical Assembly (PCA), is in the north-central area of the main ORNL site. The facility is a two-story steel framed building with corrugated metal siding. Building 3010 covers an overall area of $77 \mathrm{ft} \times 51 \mathrm{ft}$. The portion of the facility containing the pool and the 35-ft-high reactor bay occupies an area $32 \mathrm{ft}$ wide $\times 74 \mathrm{ft}$ long. The remainder of the building contains offices, instruments rooms, experiment rooms, and a small shop. The three experiment rooms are located on the main level, on the west, northwest, and northeast sides of the facility. These experiment rooms are operated by the Solid State Division. The floor plan of Building 3010 is shown in Fig. A.6.

The reactor pool is constructed from reinforced, ordinary concrete. The pool rests, at least in part, on bedrock. The interior of the pool is lined with concrete filler blocks. The inner surfaces of the pool are coated with thermosetting plastic paint to improve water tightness, aid in cleaning, enhance visibility, and minimize corrosion of the reactor components by isolating the pool from corrosive agents present in concrete. The pool has internal dimensions of $40 \mathrm{ft}$ long $\times 20 \mathrm{ft}$ wide and varies in depth from 21.5 to $27 \mathrm{ft}$. The pool holds approximately $130,000 \mathrm{gal}$ of water. Steel rails are mounted in the east and west walls of the pool for a traveling bridge that spans the width of the pool to support the reactor. An additional traveling bridge, called the instrument bridge, is used to provide a working platform and space for special equipment. 


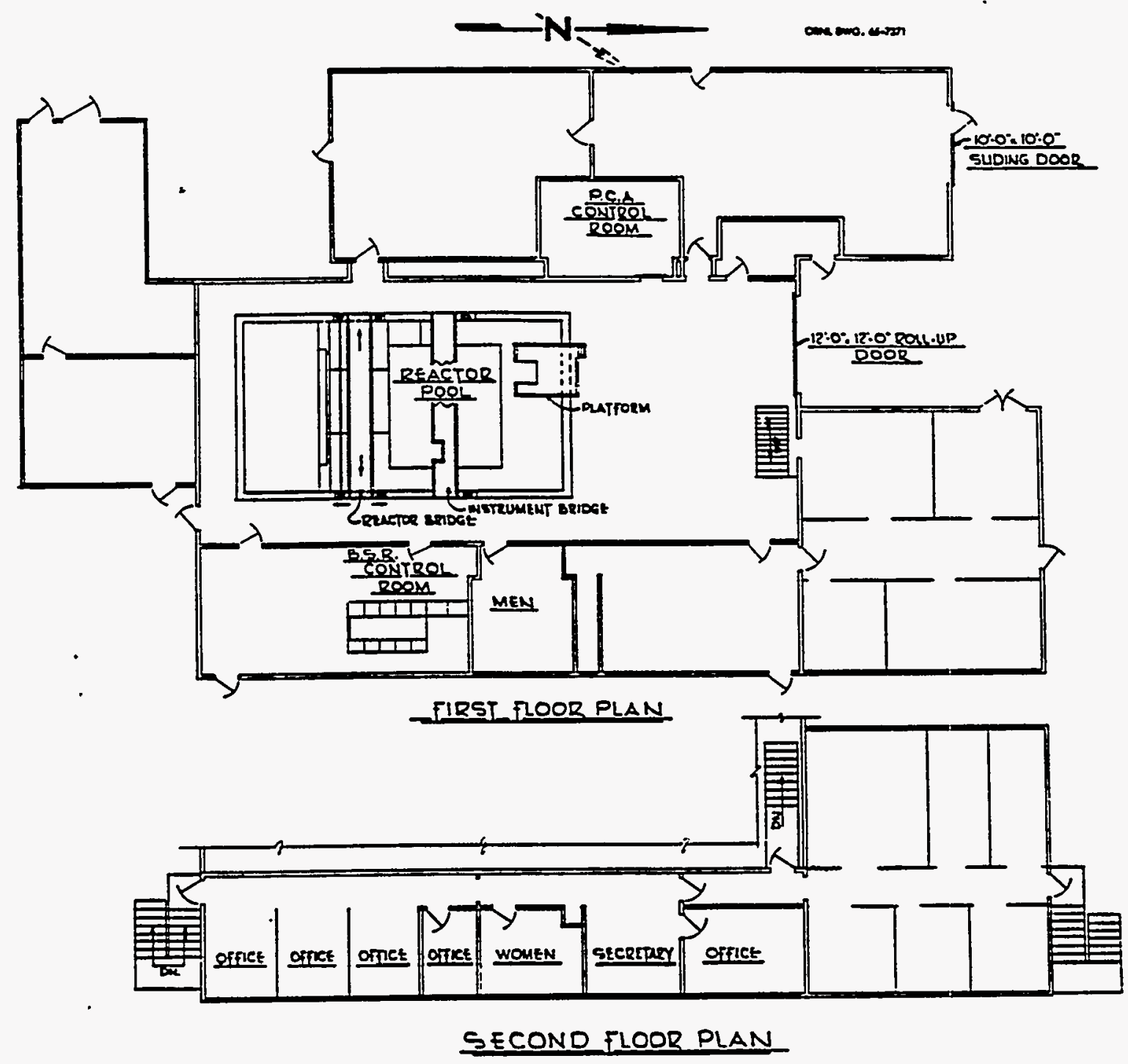

Fig. A.6. Floor plan of Building 3010. 
The PCA is a zero-power critical assembly and is very similar in construction to the BSR. It is located in a fixed position in the northwest comer of the pool. The principal modification of the facility from the BSR design is that the grid plate is arranged to accommodate both Oak Ridge Research Reactor and BSR fuel elements. The principal function of the assembly is for training and performing special tests that do not require any appreciable power level. The assembly is limited to a maximum power of $10 \mathrm{~kW}$ and is designed to duplicate the nuclear characteristics of the BSR and to provide properties similar to the Oak Ridge Research Reactor when the latter operates under conditions of low power and natural convection water cooling.

The Low Temperature Neutron Irradiation Facility (LTNIF) and associated equipment are located in the BSF pool. The south annex of the BSF consisted of a refrigeration unit and control room for LTNIF experiments. The refrigerants employed were liquid nitrogen and liquid helium. The facility was used with heavy water $\left(\mathrm{D}_{2} \mathrm{O}\right)$ for thermal neutron effects and without heavy water for fast flux effects. These experiments were sponsored by Energy Research. All of the LTNIF equipment housed in the south annex has been removed from the BSF.

The reactor assemblies, pool, instrumentation and control, utility, waste disposal, and cooling water systems are housed in the BSF. Other facility structures providing direct support to the BSF are described in the following sections.

\section{A.2.4.1.1 Building 3004-Water demineralizer facility}

Building 3004 is a $2000-\mathrm{ft}^{3}$ four-story wooden structure located west of the BSF. This facility provides pure water to Buildings 3010, 7702, 3001, 3002, and 3042. The first floor houses water treatment process equipment (i.e., caustic and acid tanks, ion columns, etc.) that are no longer in use. This system was replaced by vendor-supplied mixed resin beds also located on the first floor. Treated water is pumped to a 10,000-gal holding tank located on the top floor of the building. Rooms on the upper floors were used to support laboratory operations. These rooms are no longer in service, and the equipment has been removed from them. The building has some fixed and transferrable radioactive contamination areas. Building 3004 is protected by automatic sprinklers and monitored by the ORNL Fire Department.

\section{A.2.4.1.2 Building 3004A-Caustic tank}

Building 3004A is a 500-gal, single-lining carbon steel tank within Building 3004. This tank is used to mix sodium hydroxide solutions during the water treatment process. The tank is empty and believed to be clean.

\section{A.2.4.1.3 Building 3004B — Caustic tank}

Building 3004B is a 780-gal, single-lining carbon steel tank placed in a diked area within Building 3004. This tank provided sodium hydroxide to the water treatment process. The tank is empty and clean.

\section{A.2.4.1.4 Building 3004C-Caustic tank}

Building $3004 \mathrm{C}$ is a 500-gal, single-lining carbon steel tank within Building 3004 . This tank is used to mix sodium hydroxide solutions during the water treatment process. The tank is empty and believed to be clean. 


\section{A.2.4.1.5 Building 3004D—Nitric acid tank}

Building 3004D is an aboveground, 500-gal, single-lining stainless steel tank in a diked area adjacent to Building 3004 . This tank provided nitric acid to the water treatment process. The tank is empty and believed to be clean.

\section{A.2.4.1.6 Building 3004F-Nitric acid tank}

Building 3004F is an aboveground, 1,500-gal, single-lining stainless steel tank situated in a diked area next to Building 3004. This tank was used to mix nitric acid during the water treatment process. The tank is empty and believed to be clean.

\section{A.2.4.1.7 Building 3004H-Nitric acid tank}

Building $3004 \mathrm{H}$ is a 60 -gal, single-lining, stainless steel tank located in Building 3004. This tank provided nitric acid to the water treatment process. The tank is empty and believed to be clean.

\section{A.2.4.1.8 Building 3009 Pumphouse}

Building 3009 is a single-story, 156- $\mathrm{ft}^{3}$. concrete block structure located southwest of the BSF. This facility supported the cooling system of the reactor bay when the reactor operated at a power level of 1 $M W$. When the BSF was upgraded to a power level of $2 \mathrm{MW}$, a new system was installed and the 3009 facility was shut down. The pumps have been disconnected and removed from the facility, but the piping inside the facility is tied to the BSF reactor bay pool. The building contains eight bags of low-level waste and is scheduled for removal in the near future. More than $\mathbf{7 5}$ percent of the facility is posted as a radioactive contaminated area.

\section{A.2.4.1.9 Building 3117 Cooling tower}

Building 3117 is a single-story, $1059 \mathrm{ft}^{2}$ wood structure located east of the BSF. The cooling tower is part of the cooling system used to support the reactor bay pool. It also provided cooling water to air conditioning units in the laboratories and offices on the first and second floor east of the reactor bay. The cooling tower is no longer needed to support the reactor bay pool. However, the cooling tower continues to provide cooling water to air conditioning units. The siding on the cooling tower and pipe insulation is covered with asbestos. The redwood in the cooling tower is treated with chromate. Chromates have the potential to cause kidney damage in humans if ingested and are carcinogens if inhaled.

\section{A.2.4.1.10 Sulfuric acid tank cooling tower 3117A}

Building 3117A is an aboveground, 1,000-gal, single-lining stainless steel tank located in a diked area next to the cooling tower. The tank is empty and believed to be clean.

\section{A.2.4.1.11 Building 3119 Heat exchanger and pumphouse}

Building 3119 is a one-story, 667- $\mathrm{ft}^{2}$ concrete block structure located east of the BSF. This facility houses the heat exchanger and the pumps that supported the cooling system for the reactor bay pool. The facility and equipment contain radioactive contamination. There is a 100-gal single lining carbon steel caustic tank and a 100-gal single lining stainless steel nitric acid tank inside Building 3119. Both tanks are empty and clean. 
A.2.4.1.12. Building 3101 Storage shed

Building 3101 is a single-story, 200- $\mathrm{ft}^{2}$ reinforced concrete block structure located west of the BSF. Contaminated waste is stored inside the facility. Seventy-five percent of the building is a posted radiation area.

\section{A.2.4.1.13 Building 3088 Storage BSF}

Building 3088 is a one-story, 129- $\mathrm{ft}^{2}$ steel framed metal siding structure located northeast of the 3004 demineralizer. The facility is empty and has no radioactive contaminated areas.

\section{A.2.4.1.14 Building 3098 Filter facility BSF}

Building 3098 is a one-story, 1231- $\mathrm{ft}^{2}$ steel framed corrugated siding structure located south of the BSF. This facility houses three banks of filters that filter exhaust air from the BSF before being released to the atmosphere through a 250-ft stack. More than 75 percent of the facility contains high levels of radioactive contamination.

\section{A.2.4.1.15 Liquid nitrogen tank A-1204}

The liquid nitrogen tank is a 500-gal, aboveground cryogenic tank located west of the BSF. This tank provided liquid nitrogen to the LTNIF. The tank is empty and believed to be clean.

\section{A.2.4.1.16 Liquid helium tank 13822}

The helium tank is a 700-gal, aboveground cryogenic tank located west of the BSF. This tank supplied helium to the LTNIF. The tank is empty and believed to be clean.

\section{A.2.4.2 Facility history}

-The BSF was operated from 1951-1984 by the Union Carbide Nuclear Corporation under contract initially to the Atomic Energy Commission, then the U.S. Energy Research and Development Administration, and finally the U.S. Department of Energy (DOE). Martin Marietta Energy Systems, Inc., operated the BSF from 1984-1987, under contract to the DOE. Throughout its history, under the cognizance of the applicable federal agency and operating contractor, the BSF was used by ORNL and several other domestic, international, government, academic, and commercial personnel and organizations for isotope production, materials irradiation, radiation shielding experiments, and training for reactor operators and nuclear engineering students. Contamination at the facility is the cumulative consequence of approximately 36 years of operation and cannot be attributed to any particular individual or organization.

The BSF was originally constructed to support the Aircraft Nuclear Propulsion (ANP) Project. Conventional lead and concrete shielding were too heavy for use in aircraft, so the BSF was used to test the radiation shielding properties of other materials. After the demise of the ANP Project, the BSF continued to be used for other material shielding studies, including projects for the space program. The Mercury space capsules were submerged in the BSF Pool to determine the effects of radiation on its components.

In the early 1960s, the focus of the BSF shifted from shielding studies to experiments run by the Solid State Division examining the effects of radiation on metals and other materials at low temperatures. The 
Low Temperature Radiation Damage Studies examined the effects of irradiation on metals at liquid helium temperatures. In 1960, the original Low-Temperature Irradiation Facility (LTI) was installed at the BSF. The LTI studied the effects of thermal neutrons on the materials. Over the life of the LTI, two liquid helium cryostats were used. The cryostats were fixed to the bottom of the pool, while the reactor core was moved to adjust the distance required for particular experiments. $\mathrm{D}_{2} \mathrm{O}$ was used to moderate the neutrons. In 1985, the LTI was replaced with a third cryostat, the LTNIF, which is still in place. Unlike the original LTI, the LTNIF employed fast neutrons. The LTNIF was intended to be used as an international user research facility, but only a few test runs were performed before the BSR was put into standby. Other radiation damage experiments performed by the Solid State Division employed a liquid nitrogen cryostat or were carried out under a helium atmosphere at room temperature. Toward the end of the lifetime of the facility, the effects of radiation damage on nonmetals were examined. These materials included insulators and epoxies needed to build the superconducting magnets for fusion generators.

Another research project carried out at the BSF, performed by the Chemistry Division, was the development of a new method of constructing rectifiers for the electrical power industry. Silicon crystals were irradiated with thermal neutrons to dope the silicon with small, but uniform, concentrations of phosphorus. Production work with this process was later performed at the University of Missouri.

The Bulk Shielding Facility was placed in temporary shutdown mode in March 1987 following the shutdown of the High Flux Isotope Reactor (HFIR) because of technical and management concerns. On September 10, 1991, DOE directed ORNL to permanently shutdown the BSF. This decision was based on the limited funds available to provide financial support required for continued operation.

\section{A.2.4.3 General status}

The facilities at the BSF are generally in sound condition as conveyed by visual inspection and assurance of RRD facility managers and other RRD and ORNL Chemical Technology Division personnel. Maintaining the structure in such a condition was required to sustain the safety envelope of the BSF. The fuel stored in the reactor pool bay is the basis for maintaining the facility in that condition. Examples of maintaining the BSF in a safe configuration include, but are not limited to, the following: the reactor bay is maintained at a negative pressure because of the potential for airborne radioactive contamination, and the $\mathrm{pH}$ and resistivity of the demineralized water are maintained to provide adequate shielding in the pool and to prevent corrosion of the fuel-handling equipment and fuel storage racks. The BSF roof has some leaks. These leaks represent no immediate threat but could pose problems over the facility life cycle and before transfer to D\&D.

\section{A.2.4.3.1 Spent fuel}

The BSF houses the BSR and Oak Ridge Reactor fuel in the reactor bay pool. The fuel consists of standard MTR-type fuel elements with aluminum cladding. The spent fuel has a mass of $58.9 \mathrm{~kg}$, with a uranium-235 enrichment of 93 percent for BSR fuel, and 19 percent for Oak Ridge Research Reactor fivel. The Oak Ridge Research Reactor fuel is approximately 10 years old, while the age of the BSR fuel ranges from 12 to 25 years.

\section{A.2.4.3.2 Radioactive Sources}

There are radioactive sources stored in two locked aluminum cans in the reactor bay pool. These sources include $2000 \mathrm{Ci}$ of cobalt-60, $10 \mathrm{Ci}$ of radium, and 1.5E-4 $\mathrm{Ci}$ of antimony-124. Also, there are 
10 fission chambers used for calibration stored in a locked storage cabinet at the BSF. The reactor bay holds three aluminum tanks containing $907 \mathrm{~kg}$ of heavy water contaminated with tritium.

\section{A.2.4.3.3 Hazardous materials}

All materials potentially subject to RCRA/TSCA requirements have been removed from the BSF. 
Appendix B

SUBPROJECT SCHEDULES 
B-3

Subproject Schedules will be developed after the start of FY 1996. 


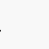


Appendix C

PROJECT COST ESTIMATES 


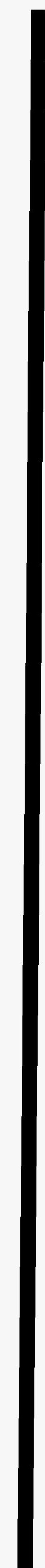




\section{C-3}

Project Cost Estimates are now in development and will be completed after the start of FY 1996 in preparation for the Life Cycle Baseline. Cost estimates are available for FY 1996 activities (See Table 4.3). 


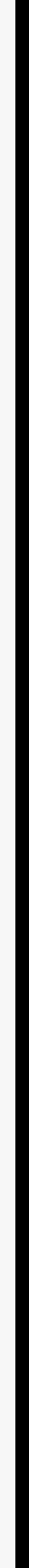


Appendix D

PROJECT SURVEILLANCE AND MAINTENANCE ACTIVITIES 


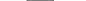




\section{CONTENTS}

D.1. INTRODUCTION TO IDENTIFIED SURVEILLANCE AND MAINTENANCE ACTIVITIES

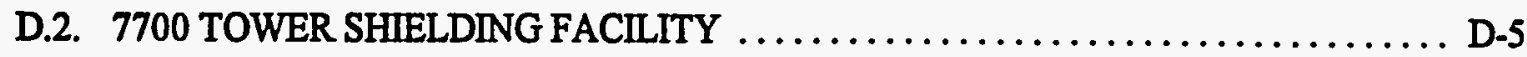

D.2.1 BUILDING 7700 TOWER SHIELDING FACILITY AND SITE CURRENT S\&M ACTIVITIES $\ldots \ldots \ldots \ldots \ldots \ldots \ldots \ldots \ldots \ldots \ldots, D-5$

D.2.2. 7700A BIG BEAM SHIELD .......................... D-11

D.2.3. 7700B OUTSIDE SOURCE STORAGE AREA $\ldots \ldots \ldots \ldots \ldots \ldots \ldots \ldots$ D-12

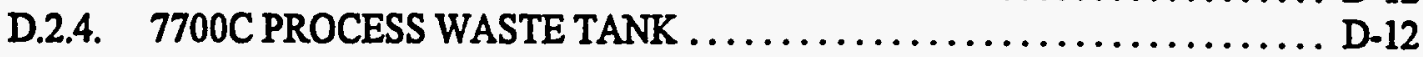

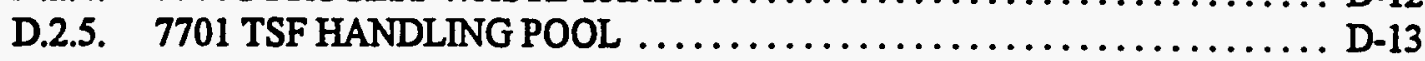

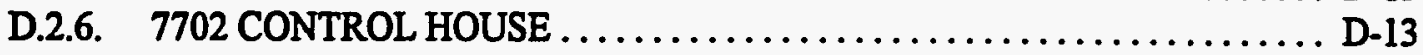

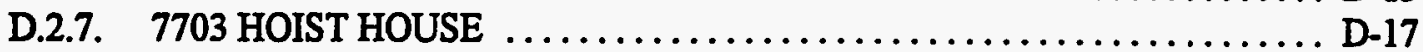

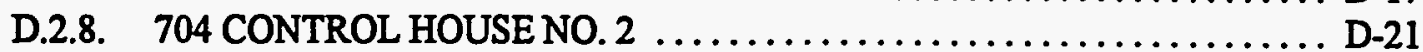

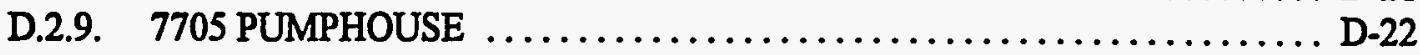

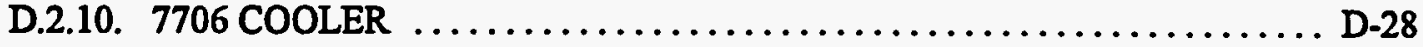

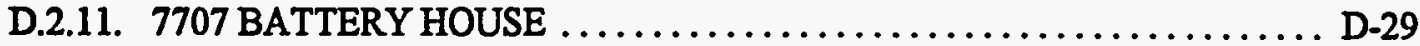

D.2.12. 7708 SHIELDING STORAGE (BUTLER BUILDING) $\ldots \ldots \ldots \ldots \ldots \ldots$ D-31

D.2.13. 7716 FILTER HOUSE - MAIN POOL $\ldots \ldots \ldots \ldots \ldots \ldots \ldots \ldots \ldots$ D-32

D.2.15. BONEYARD $\ldots \ldots \ldots \ldots \ldots \ldots \ldots \ldots \ldots \ldots \ldots \ldots \ldots \ldots \ldots \ldots \ldots \ldots$, D-33

D.3. 3010 BULK SHIELDING REACTOR FACILITY $\ldots \ldots \ldots \ldots \ldots \ldots \ldots \ldots \ldots \ldots \ldots \ldots$

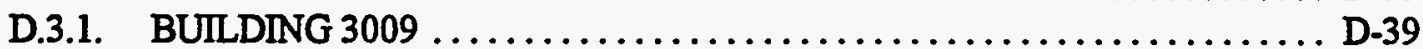

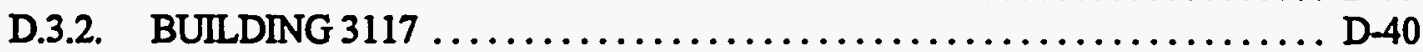

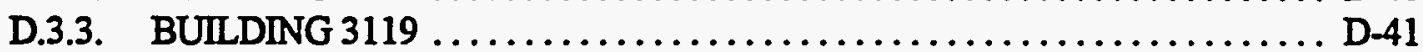

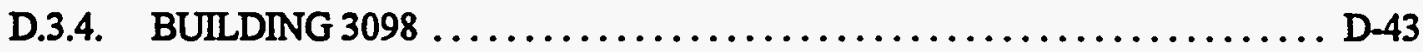

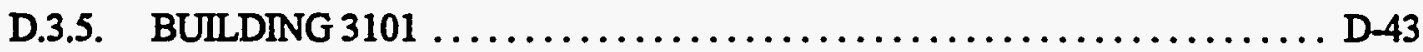

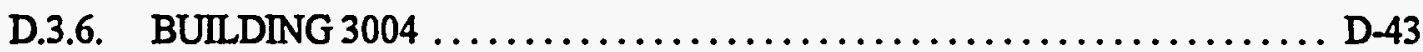

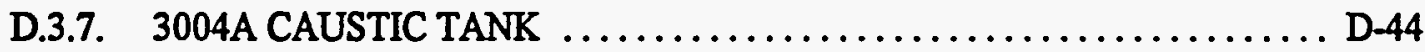

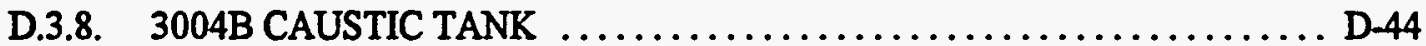

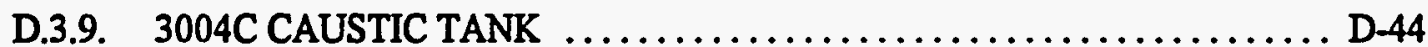

D.3.10. 3004D NITRIC ACID TANK $\ldots \ldots \ldots \ldots \ldots \ldots \ldots \ldots \ldots \ldots \ldots \ldots \ldots \ldots \ldots \ldots$, D-45

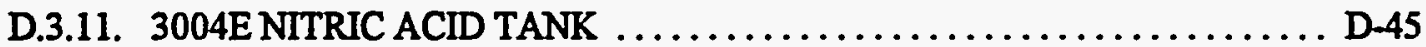

D.3.12. 3004F NITRIC ACID TANK $\ldots \ldots \ldots \ldots \ldots \ldots \ldots \ldots \ldots \ldots \ldots \ldots \ldots \ldots \ldots, \mathrm{D}-45$

D.3.13. 3004H NITRIC ACID TANK $\ldots \ldots \ldots \ldots \ldots \ldots \ldots \ldots \ldots \ldots \ldots \ldots \ldots \ldots$, D-45

D.3.14. 3117A SULFURIC ACID TANK $\ldots \ldots \ldots \ldots \ldots \ldots \ldots \ldots \ldots \ldots \ldots \ldots \ldots \ldots \ldots$

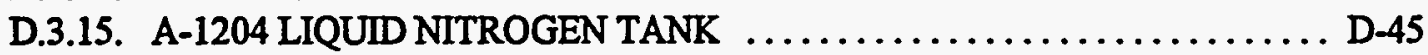

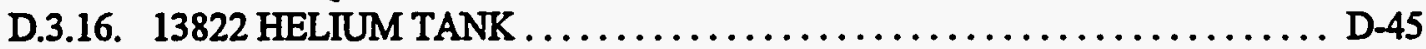

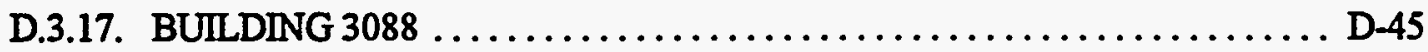

D.4. 3019B HIGH RADIATION LEVEL ANALYTICAL FACILITY $\ldots \ldots \ldots \ldots \ldots$ D-46

D.5. 7602 INTEGRATED PROCESS DEMONSTRATION FACILITY ............ D-49 
. 


\section{D.1. INTRODUCTION TO IDENTIFIED SURVEILLANCE AND MAINTENANCE ACTIVITIES}

Following is a list of current surveillance and maintenance (S\&M) activities as identified by the High Ranking Facilities Deactivation Project (HRFDP) staff and will provide the foundation for the S\&M plan. As the program evolves, activities may be added, deleted, or modified to meet current drivers. This list by facility should not be seen as final, but as a best attempt by the HRFDP team to identify all activities. All information will be input into a database and work-hour costs may be elicited by Oak Ridge National Laboratory (ORNL) divisions standard value files to perform a cost breakdown per participant and total cost per facility.

\section{D.2. 7700 TOWER SHIELDING FACILITY}

\section{D.2.1 BUILDING 7700 TOWER SHIELDING FACILITY AND SITE CURRENT S\&M ACTIVITIES}

Eacility Manager's Walk-through

- Outside air temperature-Daily

The ambient temperature is measured and recorded on the daily check list.

- Demineralized water temperature-Daily

The temperature of the demineralized water in the coolant circulation system is read and recorded on the daily check list. The minimum acceptable temperature is $40^{\circ} \mathrm{F}$.

- Check demineralized water tanks' pump-Daily

The pumps for the demineralized water tanks are checked to verify that they are in working condition. If the temperature is below $50^{\circ} \mathrm{F}$ and there is a danger of the water freezing, the pumps must be turned on.

- Pad conditions-Daily

A visual inspection of the TSF pad is made to verify that everything seems to be operating within normal parameters.

- Check demineralized water tanks' heaters-Daily (if temperature $<40^{\circ} \mathrm{F}$ )

The heaters for each of the two demineralized water tanks are checked to verify that they are turned on and operating. This check is unnecessary in warm weather when there is no danger of the water in the tanks freezing. 
- Demineralized tank water level-Daily

The water levels in the demineralized water tanks are read and recorded on the daily check list.

- Reactor weekly tests-Weekly

Reactor operational checks, as indicated in ORNL/RRD/INT - 88, are performed weekly. These include reactor operational checks, fast scram tests, personnel protection operational checks, and remote checks.

Health Physics Surveillance

- Grounds radiation survey-Annually

Radiological surveys of the outdoor areas around the Tower Shielding Facility (TSF) are conducted annually to identify any contaminated areas not identified previously.

Resource Requirement: 79 work-hours

- Tower shielding pad survey-Monthly

Radiological surveys are conducted to identify which areas in the building are safe to enter without protective clothing and which contain radioactive contamination. The radiological surveys are done in accordance with RPP-110, the ORNL Radiological Control Policy, the ORNL Radiological Protection Procedure Manual, and 10 CFR Part 835, "Occupational Radiation Protection." Resource Requirement: 95 work-hours.

\section{Plant and Equipment (P\&E) Division Programmed Maintenance}

- Facility inspection-Annually

An annual inspection of the TSF is performed by P\&E personnel. This activity includes checking the alignment of the towers, the tower base, the gury anchor pin, and the elevations.

Resource Requirement: 96 work-hours

- Lightning protection-Annually

An annual lightning protection inspection of the TSF is performed by P\&E personnel. This activity includes measuring and recording the lightning protection resistance to the ground and checking the condition of the system.

Resource Requirement: 6 work-hours

- Tower shielding fire reservoir tank-Annually

An annual inspection of the Valve TSF fire reservoir tank is performed by P\&E personnel. This activity includes checking the float operation control, valve operation, diaphragm, gasket, electric heater, and hilo alarm.

Resource Requirement: 6 work-hours 
- 600-ft perimeter fence gate-Annually

An annual inspection of the TSF electric operating gate 600-ft fence is performed by P\&E personnel. This activity includes checking belt wear, tension and alignment, brake parts, and lubricating moving parts.

Resource Requirement: 4 work-hours

- 600 -ft perimeter fence gate No. 2-Annually

An annual inspection of the TSF electric operating gate 2 (600-ft fence) is performed by P\&E personnel. This activity includes lubricating motor bearings and other moving parts and checking belt wear, tension, and alignment and brake parts.

Resource Requirement: 4 work-hours

- Fence inspection-Annually

An annual inspection of fences for Health Physics Research Reactor (HPRR) \& TSF is performed by P\&E personnel. This activity includes inspecting TSF $600-\mathrm{ft}$ fence and HPRR \& TSF fence.

Resource Requirement: 4 work-hours

- Forklift inspection-Semiannually

A semiannual inspection of the gas lift includes checking crankcase oil, filter, and breather, and inspecting and maintaining transmission, brake, steering hydraulics clutch, radiator, and belts.

Resource Requirement: 10 work-hours

- Galion crane inspection-Quarterly

The Galion 8-ton 17-6709 crane is inspected once every 3 months by P\&E personnel. This activity includes cleaning and maintaining fluids and filters of major systems and the crane boom table.

Resource Requirement: 9 work-hours

- Cable guide rollers-Annually

An annual inspection of the cable guide rollers (12) includes cleaning and lubricating rollers and bearings.

Resource Requirement: 6.5 work-hours

- Cable idler sheaves-Annually

An annual inspection of the cable idler sheaves (4) includes lubricating sheave shaft bearings and lubricating the sheaves.

Resource Requirement: 2 work-hours

- Ground hoist sheaves

An amnual inspection of the ground hoist sheaves (6) includes lubricating sheave shaft and bearings and cleaning the hoist sheave and housing.

Resource Requirement: 4 work-hours 
- Condenser inspection-Semiannually

A semiannual inspection of the condenser air-cooler carrier includes lubricating motor and fan shaft bearings and checking belts, switches, and controls.

Resource Requirement: 1 work-hour

- Fan supply dryer inspection-Semiannually

A semiannual inspection of the fan supply dryer dynamics includes lubricating motor bearings, cleaning motor and fan, disconnecting switch, and changing filters.

Resource Requirement: 0.75 work-hour

- Condenser air-cooled carrier-Semiannually

A semiannual inspection of the condenser air-cooler carrier includes lubricating motor and fan shaft bearings, and checking belts, switches, and controls.

Resource Requirement: 0.75 work-hour

- Cable guide roller-Annually

An annual inspection of the cable guide roller includes cleaning and lubricating the roller and shaft. Resource Requirement: 0.75 work-hour

- Hoist for aircraft waming lights north-Annually

An annual inspection of the hoist for the north aircraft warning lights includes lubricating gears, cables, and all moving parts; checking handbrakes; and cleaning all controls and switches.

Resource Requirement: 12 work-hours

\section{- Otis TSF elevator-Quarterly}

A quarterly inspection of the Otis TSF elevator includes lubricating bearings, cables, doors, shafts, etc.; maintaining gearcase and brakes; and checking electrical components.

Resource Requirement: 60 work-hours

- Cable guide roller-Annually

An annual inspection of the cable guide roller includes cleaning and lubrication of the roller and shaft. Resource Requirement: 0.75 work-hour

- Boston gear reducer-Semiannually

A semiannual inspection of the Boston gear reducer includes inspecting seal bearings; lubricating the shaf, chain, and other moving parts; checking electrical components; and cleaning the motor and gear unit.

Resource Requirement: 2 work-hours 
- Trane air-cooled condenser by ramp-Annually

Annual inspection of the Trane Air-Cooled Condenser includes cleaning fan, fins, and motor, and checking conditions of fan blades.

Resource Requirement: 0.5 work-hour

- TSF leg No. 1-Annually

Annual inspection includes lubricating travel block sheath and hoistings and checking for completion of cable lubrication.

Resource Requirement: 2 work-hours

- TSF hoist B-Annually

Annual inspection includes lubricating all sheave pins and hoisting sling and checking for cable lubrication.

Resource Requirement: 12 work-hours

- TSF leg No. 4-Annually

Annual inspection includes lubricating travel block sheath and hoistings and checking for completion of cable lubrication.

Resource Requirement: 2 work-hours

- TSF leg No. 3-Annually

Annual inspection includes lubricating travel block sheath and hoistings and checking for completion of cable lubrication.

Resource Requirement: 2 work-hours

- TSF hoist D-Annually

Annual inspection includes lubricating travel block sheath and hoistings and checking for completion of cable lubrication.

Resource Requirement: 12 work-hours

- TSF leg No. 2-Annually

Annual inspection includes lubricating travel block sheath and hoistings and checking for completion of cable lubrication.

Resource Requirement: 2 work-hours

- Hoist for aircraft warning light south-Annually

An annual inspection of the hoist for the south aircraft warning lights includes lubricating gears, cables, and all moving parts; checking handbrakes; and cleaning all controls and switches.

Resource Requirement: 12 work-hours 
- Tower anchor screws-Annually

Annual inspection of Tower anchor screws includes lubricating anchor screws with a brush.

Resource Requirement: 12 work-hours

- Allis Chalmers Demineralized Water Circulation Pump-Annually

Annual inspections of the Allis Chalmers Demineralized Water Circulation Pump includes lubricating valve stems and motor bearings; checking bearing oil, shaft couplings; and packaging; and replacing motor oil.

Resource Requirement: 1.25 work-hours

- Corded equipment 7700 Area-Every 2 years

Once every 2 years, inspect and replace all electrical power cords as needed.

Resource Requirement: 3 work-hours

- Transformer 1, 167KVA Station 234-23 PCB-Every 2 years

Once every 2 years, visually inspect the transformer and report observations; check the oil level; look for signs of overheating, voltage creep, loose connections, and corrosion; and measure winding, contact, and insulation resistance.

Resource Requirement: 4 work-hours

- Transformer 2, 167KVA Station 234-23 PCB-Every 2 years

Once every 2 years, visually inspect transformer and report observations; check oil level; look for signs of overheating, voltage creep, loose connections, and corrosion; and measure winding; contact, and insulation resistance.

Resource Requirement: 4 work-hours

- Transformer 3, 167KVA Station 234-23 PCB-Every 2 years

Once every 2 years, visually inspect transformer and report observations; check oil level; look for signs of overheating, voltage creep, loose connections, and corrosion; and measure winding; contact, and insulation resistance. Resource Requirement: 4 work-hours

- Floor tile inspection-Annually

A visual inspection assesses the condition and rate of deterioration of the floor tiles. Resource Requirement: 0.5 work-hour

\section{P\&E Division Non-routine Maintenance}

Non-routine maintenance activities are not scheduled but performed on an as-needed basis. Non-routine activities and their associated resource requirements performed in FY 1994 will be used to predict the levels of funding that should be set aside for such activities in the future.

In FY 1994, the largest nonroutine maintenance tasks include testing and greasing of the tower gury cables and the testing of the tower bases. Other tasks consisted of relamping, installing heat traces, 
insulating water lines, replacing GFIs, inspecting ladders, dismantling frames, coupling hoses, cleaning up the facility, etc.

Resource Requirement: 1833 work-hours

Instrument and Controls (I\&C) Division surveillance and maintenance

The I\&C Division has no routine surveillance activities scheduled at this facility.

\section{Quality assurance}

- Safety Inspection-Annually

QA performs annual safety inspections on all ORNL facilities.

Resource Requirement: 20 work-hours

\section{D.2.2. 7700A BIG BEAM SHIELD}

Eacility Manager's walk-through

- Turret conditions-Daily

This is a general check to see that nothing unusual is occurring in the reactor control turret.

- Temperature-Daily

The temperature in the big beam shield is read and recorded in the daily check list. The minimum acceptable temperature is $40^{\circ} \mathrm{F}$.

- Reactor turret temperature-Daily

The temperature in the reactor core is measured and recorded in the daily check list. The minimum acceptable temperature is $40^{\circ} \mathrm{F}$.

- Shim line temperature-Daily

The temperature in the shim line bringing cooling water from the shim pump in Building 7705 to the reactor is measured and recorded on the daily check list. The minimum acceptable temperature is $40^{\circ} \mathrm{F}$.

- Core inlet pressure-Daily

The pressure of the cooling water entering the reactor core is measured and recorded on the daily check list.

- Heater-Daily (if temperature $<50^{\circ}$ )

The heater of the big beam shield is checked to verify that it is turned on and operating. This activity is unnecessary during warm weather when there is no danger of coolant freezing. 


\section{D-12}

Health Physics Surveillance

The Health Physics Division has no routine surveillance on the facility.

\section{P\&EDivision Programmed Maintenance}

No routine maintenance activities by the P\&E Division are scheduled at this facility.

\section{P\&E Division Non-routine Maintenance}

The P\&E Division conducted no nonroutine maintenance at the facility in FY 1994.

Resource Requirement: 0 work-hours

I\&C Division Surveillance and Maintenance

The I\&C Division has no routine surveillance activities scheduled at this facility.

\section{D.2.3. 7700B OUTSIDE SOURCE STORAGE AREA}

\section{Facility Manager's Walk-through}

No routine surveillance by the facility manager is scheduled at this facility.

\section{Health Physics Surveillance}

The Health Physics Division has no routine surveillance on the facility.

\section{P\&E Division Programmed Maintenance}

No routine maintenance activities by the P\&E Division are scheduled for this facility.

\section{P\&E Division Non-routine Maintenance}

The P\&E Division performed no nonroutine maintenance at this facility in FY 1994.

I\&CDivision Surveillance and Maintenance

The I\&C Division has no routine surveillance activities scheduled at this facility.

\section{D.2.4. 7700C PROCESS WASTE TANK}

\section{Eacility Manager's Walk-through}

- Water level-Daily

The water level in the tank is measured and recorded on the daily check list. 
Health Physics Surveillance

The Health Physics Division has no routine surveillance on the facility.

P\&EDivision Programmed Maintenance

No routine maintenance activities by the $P \& E$ Division are scheduled at this facility.

\section{P\&E Division Non-routine Maintenance}

The P\&E Division conducted no nonroutine maintenance at this facility in FY 1994.

I\&C Division Surveillance and Maintenance

The I\&C Division has no routine surveillance activities scheduled at this facility.

\section{D.2.5. 7701 TSF HANDLING POOL}

\section{Eacility Manager's Walk-through}

No routine surveillance by the facility manager is scheduled at this facility.

Health Physics Surveillance

The Health Physics Division has no routine surveillance on the facility.

\section{P\&E Division Programmed Maintenance}

No routine maintenance activities by the P\&E Division are scheduled at this facility.

\section{P\&EDivision Nonroutine Maintenance}

The P\&E Division performed no nonroutine maintenance at this facility in FY 1994.

I\&C Division Surveillance and Maintenance

The I\&C Division has no routine surveillance activities scheduled at this facility.

\section{D.2.6. 7702 CONTROL HOUSE}

\section{Eacility Manager's Walk-through}

- AC fan-Daily

The alternating current fan is checked to verify that it is turned on and operating. 
- Exit routes-Daily

The exit routes to the north and south ramps are checked to verify that they are clear and can be used in an emergency.

- Exit and emergency lights-Daily

The exit light at the north exit, the two exit lights at the south ramp, and all emergency lights are checked to verify that they are working properly.

- Monitrons-Daily

The continuous air monitrons at the north exit, the south ramp, and in the hall connecting Buildings $\mathbf{7 7 0 2}$ and 7704 are checked to verify that they are turned on and operating properly.

- Fire protection-Daily

The fire protection system is checked to verify that it is operating properly.

- Potable water pressure-Daily

The pressure of the potable water supply of the TSF is measured and recorded on the daily check list. The minimum acceptable pressure is $70 \mathrm{psig}$.

- Air pressure-Daily

The air pressure in the control room is read and recorded on the daily check list. The minimum acceptable air pressure is $42 \mathrm{psig}$.

- Electrometers - Daily

The electrometer on the south exit ramp and the electrometer on the experiment pad are checked to verify that they are turned on and are operating correctly.

Health Physics Surveillance

- Radiological surveys-Weekly

Radiological surveys are conducted to identify which areas in the building are safe to enter without protective clothing and which contain radioactive contamination. The radiological surveys are done in accordance with RPP-110, the ORNL Radiological Control Policy, the ORNL Radiological Protection Procedure Manual, and 10 CFR Part 835, "Occupational Radiation Protection." Resource Requirement: 285 work-hours. 


\section{P\&E Division Programmed Maintenance}

- Fan supplier dryer dynamics-Quarterly

A quarterty fan supplier dryer inspection includes lubricating motor bearings, checking belts, filters and switches, and cleaning motor and fan.

Resource Requirement: 4 work-hours

- Electrical distribution controls-Every 4 months

Inspect, clean, and check panels, breakers, transformers, switches, contacts, and terminals once every 4 months.

Resource Requirement: 9 work-hours

- Circuit breaker-Every 4 months

Inspect, clean, and calibrate all mechanical and electrical components and replace as needed every 4 months.

Resource Requirement: 9 work-hours

- Dayton air compressor-Quarterly

Check crankcase oil level, check and clean air filter, drain receiver tank, and clean motor and compressor unit.

Resource Requirement: 6 work-hours

- Copelamatic Freon $12 \mathrm{~A} / \mathrm{C}$ compressor-Semiannually

Lubricate motor bearings; check couplings, pins, crankcase oil level, controls, gauges, and inventory of spare parts; and flush and refill crankcase twice a year.

Resource Requirement: 0.75 work-hour

- Trane climate changer-Semiannually

Lubricate motor bearings; check belts; lubricate fan shaft; clean fan, pan, coils, and plenum; and change filters twice a year.

Resource Requirement: 1 work-hour

- Electrical distribution controls-Annually

Inspect, clean, and check operation of panels, switches, controls, contacts, and terminals every year. Resource Requirement: 3 work-hours

\section{- Carrier Weathermaker A/C No. 1-Semiannually}

Twice a year lubricate fan drive motor bearings; check belts, filters, compressor oil level, controls, and gauges; and clean fan pan coils and plenum.

Resource Requirement: 6.5 work-hours 
- Joy air compressor-Quarterly

Every 3 months lubricate motor bearings; check belts, crankcase oil level, controls, and gauges; drain receiver air tank; and clean air filters, motor, and compressor unit.

Resource Requirement: 8 work-hours

- Carrier Weathermaker A/C No. 2-Semiannually

Twice a year lubricate all bearings; check belt, filters, compressor oil level, controls, and gauges; and clean fan pan, coils, and plenum.

Resource Requirement: 6.5 work-hours

- Building exhaust damper-Quarterly

Four times a year evaluate the operation of the building exhaust damper.

Resource Requirement: 2.9 work-hours

- Lathe 12.5" Cincinnati-Annually

Every year lubricate gears and all moving parts, and clean filters, pumps, lathe, and electrical components.

Resource Requirement: 0.33 work-hour

- Brake D1 Acro No. 3-Annually

Lubricate all bearings and pins, and check and clean the brake annually.

Resource Requirement: 0.17 work-hour

- Grinder Bench Walker Turner-Annually

Check and clean electrical and mechanical components; check safety shields and dress stones annually. Resource Requirement: 0.25 work-hour

- Drill Press Walker Turner -Annually

Lubricate spindle parts, lock plugs, rack and pinion gear, and table column; clean electrical and mechanical components.

Resource Requirement: 0.17 work-hour

- Saw Band Vertical Powermatic-Annually

Lubricate bearings and moving parts, check belt wear, maintain crankcase, and clean welder parts, electrical components, motor, and operation of unit.

Resource Requirement: 0.33 work-hour

\section{P\&EDivision Nonroutine Maintenance}

Non-routine maintenance activities are not scheduled, but performed on an as-needed basis. Non-routine activities and their associated resource requirements performed in FY 1994 will be used to predict the levels of funding that should be set aside for such activities in the future. 
In FY 1994, major nonroutine maintenance tasks consisted of the installation of insulation panels, the replacement of sprinkler heads, the repositioning of the ventilation system motor, and miscellaneous electrical work.

Resource Requirement: 115 work-hours

\section{I\&C Division Suryeillance and Maintenance}

- Biannual calibrations-Every 2 years

The PE-10A and PE-10C transducer presses are calibrated once every 2 years.

Resource Requirement: 2 work-hours

- Annual calibrations-Annually

The FR-103 and TR-101 pneumatic roll recorders are recalibrated annually. The $\mathrm{pH}$ and electrical resistivity meters are also annually calibrated, along with the FI-104, PI-10C, and PI-104 digital meters Resource Requirements: 14 work-hours

- Semiannual calibrations-Semiannually

The PDI-106 pressure gauge and the PDS-106B switch pressure gauge are recalibrated every 6 months by the I\&C Division. The TR-1600, RR-1000, and air temperature programmable recorders are also calibrated twice per year.

Resource Requirement: 20 work-hours

- Preventive maintenance-Semiannually

Preventive maintenance is performed on the anemograph recorder every 6 months.

Resource Requirement: 6 work-hours

\section{I\&C Nonroutine Maintenance}

Non-routine maintenance activities are not scheduled, but performed on an as-needed basis. Non-routine activities and their associated resource requirements performed in the past will be used to predict the levels of funding that should be set aside for such activities in the future.

Between April 1994 and April 1993, the I\&C Division carried out numerous nonroutine maintenance tasks in the 7702 Control House.

Resource Requirement: 191.5 hours

\section{D.2.7. 7703 HOIST HOUSE}

\section{Facility Manager's Walk-through}

No routine surveillance by the facility manager is scheduled at this facility. 


\section{Health Physics Surveillance}

- Radiation surveys-Annually

Radiological surveys are conducted to identify which areas in the building are safe to enter without protective clothing and which contain radioactive contamination. The radiological surveys are done in accordance with RPP-110, the ORNL Radiological Control Policy, the ORNL Radiological Protection Procedure Manual, and 10 CFR Part 835, “Occupational Radiation Protection." Resource Requirement: 8 work-hours.

\section{P\&E Division Programmed Maintenance}

- 4403-Phase hoist disconnect switch inspection-Annually

An annual 4403-phase hoist disconnect switch inspection is conducted by P\&E personnel. This activity includes cleaning, checking the operation, and adjusting the hoist disconnect switch.

Resource Requirement: 3 work-hours

- Hoist control circuit panel inspection-Annually

An amual hoist control circuit panel inspection is performed by $P \& E$ personnel. This activity includes cleaning, checking the operation, and adjusting the wiring system, bell relay, GE transformer CAT $76 \mathrm{G} 129$, and light and reception panel.

Resource Requirement: 3 work-hours

- Whiting hoist No. $1(12,000 \mathrm{lbs}$, series 7376$)$ inspection-Annually

An annual Whiting hoist No. 1 (12,000 lbs, series 7376) inspection is performed by P\&E personnel. This activity includes lubricating the main drive meter bearings; checking the slip rings and brushes on the meter; lubricating the DC generator bearings; checking the commutator and brushes on the generator; checking the couplings and shaft pins, lubricating the field brake shaft bearing; inspecting and checking the operating field brake; inspecting and checking the operating magnetic brakes; checking the brake drums and linings; lubricating the main drive shaft bearings; checking and cleaning the centrifugal switch; checking the gearcase oil level; draining, flushing, and refilling the gearcase; lubricating the drum bull gear and pinion shaft bearings; lubricating the hoisting cable; lubricating the footings on the cable guide roller; checking the electrical components; and lubricating the cable grooves.

Resource Requirement: 12 work-hours

- General Electric control unit No. 1 inspection-Annually

An annual General Electric control unit No. 1 inspection is performed by P\&E personnel. This activity includes inspecting; cleaning; checking the operation; adjusting the wiring, insulation, and connections; tightening screws; vacuuming the cabinet area; and checking and cleaning the resistor bank. Resource Requirement: 3 work-hours

- Whiting hoist $\mathrm{B}(11,000 \mathrm{lbs}$, series 7380$)$ inspection-Annually

An annual Whiting hoist B (11,000 lbs, series 7380$)$ inspection is performed annually by P\&E persomel. This activity includes lubricating the main drive meter bearings; checking the slip rings and 
brushes on the meter; lubricating the DC generator bearings; checking the couplings and shaft pins; lubricating the field brake shaft bearings; checking and cleaning the centrifugal switch; checking the gear case oil level; draining, flushing, and refilling the gear case; lubricating the drum bull gear and pinion; lubricating the drive pinion shaft bearing; lubricating the drum shaft bearings; lubricating the hoisting cable; lubricating the footing on the cable guide roller; checking all the electrical components; and lubricating the drum cable and grooves.

Resource Requirement: 12 work-hours

\section{- General Electric control unit B inspection-Annually}

An annual General Electric control unit B inspection is performed annually by P\&E personnel. This activity includes inspecting; cleaning; checking the operation; adjusting the wiring, insulation, and connections; tightening screws; vacuruming the cabinet area; and checking and cleaning the resistor bank. Resource Requirement: 12 work-hours

- Whiting hoist No. 4 (11,000 lbs, series 7379) inspection-Annually

An annual Whiting hoist No. 4 (11,000 lbs, series 7379) inspection is performed by P\&E personnel. This activity includes lubricating the main drive meter bearings; checking the slip rings and brushes on the meter, lubricating the DC generator bearings; checking the couplings and shaft pins; lubricating the field brake shaft bearings; checking and cleaning the centrifugal switch; checking the gear case oil level; driving, flushing, and refilling the gear case; lubricating the drum bull gear and pinion; lubricating the drive pinion shaft bearing; lubricating the drum shaft bearings; lubricating the hoisting cable; lubricating the footing on the cable guide roller; checking all the electrical components; and lubricating the drum cable and grooves.

Resource Requirement: 12 work-hours

\section{- General Electric control unit No. 4 inspection-Annually}

An annual General Electric control unit No. 4 inspection is performed annually by P\&E personnel. This activity includes inspecting; cleaning; checking the operation; adjusting the wiring, insulation, and connections; tightening screws; vacuuming the cabinet area; and checking and cleaning the resistor bank. Resource Requirement: 3 work-hours

- Positioning hoist electrical control panel inspection-Annually

An annual positioning hoist electrical control panel inspection is performed annually by $P \& E$ personnel. This activity includes inspecting; cleaning; checking the operation; adjusting the wiring, insulation, and connections; tightening screws; vacuuming the cabinet area; and checking and cleaning the resistor bank. Resource Requirement: 1 work-hour

- Whiting hoist No. 3 (11,000 lbs, series 7831) inspection-Annually

An annual Whiting hoist No. 3 (11,000 lbs, series 7831) inspection is performed by P\&E personnel. This activity includes lubricating the main drive meter bearings; checking the slip rings and brushes on the meter, lubricating the DC generator bearings; checking the couplings and shaft pins; lubricating the field brake shaft bearings; checking and cleaning the centrifugal switch; checking the gear case oil level; driving, flushing, and refilling the gear case; lubricating the drum bull gear and pinion; lubricating the drive pinion shaft bearing; lubricating the drum shaft bearings; lubricating the hoisting cable; lubricating 
the footing on the cable guide roller; checking all the electrical components; and lubricating the drum cable and grooves.

Resource Requirement: 12 work-hours

- General Electric control unit inspection-Annually

An annual General Electric control unit No. 3 inspection is performed annually by P\&E personnel. This activity includes inspecting; cleaning; checking the operation; and adjusting the wiring, insulation, and connections; tightening screws; vacuuming the cabinet area; and checking and cleaning the resistor bank. Resource Requirement: 3 work-hours

- Whiting hoist $\mathrm{D}(11,000 \mathrm{lbs}$, series 7378$)$ inspection-Annually

An annual Whiting hoist D (11,000 lbs, series 7378$)$ inspection is performed by $P \& E$ personnel. This activity includes lubricating the main drive meter bearings; checking the slip rings and brushes on the meter; lubricating the DC generator bearings; checking the couplings and shaft pins; lubricating the field brake shaft bearings; checking and cleaning the centrifugal switch; checking the gear case oil level; driving, flushing, and refilling the gear case; lubricating the drum bull gear and pinion; lubricating the drive pinion shaft bearing; lubricating the drum shaft bearings; lubricating the hoisting cable; lubricating the footing on the cable guide roller; checking all the electrical components; and lubricating the drum cable and grooves.

Resource Requirement: 12 work-hours

- General Electric control unit D inspection-Annually

An annual General Electric control unit $D$ inspection is performed annually by P\&E personnel. This activity includes inspecting, cleaning, checking the operation, and adjusting the wiring, insulation and connections, tighten screws, vacuum the cabinet area, check and clean the resistor bank.

Resource Requirement: 3 work-hours

- Whiting hoist No. 2 (12,000 lbs, series 7377) inspection-Annually

An annual Whiting hoist No. 2 (12,000 lbs, series 7377) inspection is performed by P\&E personnel. This activity includes lubricating the main drive meter bearings; checking the slip rings and brushes on the meter; lubricating the DC generator bearings; checking the couplings and shaft pins; lubricating the field brake shaft bearings; checking and cleaning the centrifugal switch; checking the gearcase oil level; driving, flushing, and refilling the gearcase; lubricating the drum bull gear and pinion; lubricating the drive pinion shaft bearing; lubricating the dnum shaft bearings; lubricating the hoisting cable; lubricating the footing on the cable guide roller; checking all the electrical components; and lubricating the drum cable and grooves.

Resource Requirement: 12 work-hours

- General Electric control unit No. 2 inspection-Annually

An amnual General Electric control unit No. 2 inspection is performed by P\&E personnel. This activity includes inspecting; cleaning; checking the operation; adjusting the wiring, insulation, and connections; tightening screws; vacuuming the cabinet area; and checking and cleaning the resistor bank.

Resource Requirement: 3 work-hours 
- Maintenance of roofs inspection-Annually

An annual inspection of the maintenance of the roofs is performed by P\&E personnel. This includes following guidelines of inspection as stated in the UCN 8953 form.

Resource Requirement: 4 work-hours

\section{R\&EDivision Nonroutine Maintenance}

Non-routine maintenance activities are not scheduled, but performed on an as-needed basis. Non-routine activities and their associated resource requirements performed in FY 1994 will be used to predict the levels of funding that should be set aside for such activities in the future.

In FY 1994, the major nonroutine maintenance task was the testing and repairing of one of the hoists. Resource Requirement: 24 work-hours

\section{I\&C Division Surveillance and Maintenance}

The I\&C Division has no routine surveillance activities scheduled at this facility.

\section{D.2.8. 7704 CONTROL HOUSE NO. 2}

\section{Eacility Manager's Walk-through}

- DC fan-Daily

The direct current fan is checked to verifty that it is turned on and operating.

- Exit routes-Daily

The exit routes to the escape hatch are checked to verify they are clear and can be used in an emergency.

- Exit and emergency lights-Daily

The exits light at the escape hatch and all emergency lights are checked to verify that they are working properly.

- Monitron-Daily

The continuous air monitrons at the escape hatch is checked to verify that it is turned on and operating properly.

\section{Health Physics Surveillance}

- Radiation and contamination survey-Weekly

Radiological surveys are conducted to identify which areas in the building are safe to enter without protective clothing and which contain radioactive contamination. The Radiological surveys are conducted to identify which areas in the building are safe to enter without protective clothing and which contain 
radioactive contamination. The radiological surveys are done in accordance with RPP-110; the ORNL Radiological Control Policy, the ORNL Radiological Protection Procedure Manual, and 10 CFR Part 835, “Occupational Radiation Protection." Resource Requirement: 146 work-hours.

\section{P\&E Division Programmed Maintenance}

No routine maintenance activities by the P\&E Division are scheduled at this facility.

\section{P\&E Division Nonroutine Maintenance}

Non-routine maintenance activities are not scheduled but performed on an as-needed basis. Non-routine activities and their associated resource requirements performed in FY 1994 will be used to predict the levels of funding that should be set aside for such activities in the future.

Non-routine activities in FY 1994 consisted of moving equipment and materials into and out of the building.

Resource Requirement: 8 work-hours

I\&C Division Surveillance and Maintenance

The I\&C Division has no routine surveillance activities scheduled at this facility.

\section{D.2.9. 7705 PUMPHOUSE}

\section{Eacility Manager's Walk-through}

- Nash air compressor-Daily

The Nash air compressor is checked to verify that it is turned on and operating. The air pressures in the receiver, separator, and seal are measured and recorded on the daily check lists. The maximum acceptable pressures for these measurements are $85 \mathrm{psig}, 95 \mathrm{psig}$, and $50 \mathrm{psig}$, respectively.

\section{- Air dryer-Daily}

The air flow rate through the dryer is checked and recorded on the daily check list. The pressures in both the right and left chamber of the dryer are also checked and recorded. The minimum acceptable pressures are 45 psig in both chambers.

- Water activity-Daily

The flowrate of cooling water through the system is measured and recorded on the daily check list. The minimum acceptable flowrate is $0.1 \mathrm{gal} /$ minute.

- System base and reference pressures

The base and reference pressures of the coolant circulation system is measured and recorded on the daily check list. 
- Demineralizer flow rate-Daily

The flow rate through the demineralizer is read and recorded on the daily check list.

- Demineralizer inlet pressure—Daily

The pressure of the water entering the demineralizer is read and recorded on the daily check list.

- Demineralizer outlet pressure-Daily

The pressure of the water leaving the demineralizer is read and recorded on the daily check list.

- Coolant water resistivity-Daily

The electrical resistivity of the cooling water is measured at both the inlet to the demineralizer and the outlet. These values are recorded on the daily check list. Minimum acceptable electrical resistivity of the water exiting the demineralizer is $5 \times 10^{5} \mathrm{Ohm}-\mathrm{cm}$.

- Check demineralizer pump-Daily

This demineralizer pump is checked to verify that it is turned on and operating.

- Demineralizer pump inlet pressure - Daily

The inlet pressure to the demineralizer pump is read and recorded on the daily check sheet. The minimum acceptable pressure is 5 psig.

- Demineralizer pump outlet pressure-Daily

The outlet pressure to the demineralizer pump is read and recorded on the daily check sheet.

8 Filter press upstream inlet pressure-Daily

The inlet pressure upstream of the filter press is read and recorded on the daily check list.

- Filter press upstream outlet pressure-Daily

The outlet pressure upstream of the filter pressure is read and recorded on the daily check list.

- Filter Press Downstream Inlet Pressure-Daily

The inlet pressure downstream of the filter press is read and recorded on the daily check list.

- Check main pump-Daily

The main pump is checked to verify that it is turned on and operating.

- Main pump outlet pressure-Daily 
The outlet pressure of the main coolant circulation pump is read and recorded on the daily check list.

- Check DC pump-Daily

The battery-powered DC pump is checked to verify that it is turned on and operating.

- DC pump outlet pressure-Daily

The outlet pressure of the DC pump is read and recorded on the daily check list.

- Check shim pump-Daily

The shim pump, which delivers cooling water to the reactor control turret, is checked to verify that it is turned on and operating.

- Shim pump drip rate-Daily

The shim pump is checked to verify that the drip rate is satisfactory. It is not necessary to record the drip rate on the daily check list.

- Shim pump inlet pressure-Daily

The inlet pressure to the shim pump is read and recorded on the daily check list.

- Shim pump outlet pressure-Daily

The outlet pressure from the shim pump is read and recorded on the daily check list.

- Exhaust fans-Daily

The exhaust fan in the demineralizer room and the exhaust fan in the pump room are checked to verify that they are turned on and operating.

- Check heater tapes (if temperature $<50^{\circ} \mathrm{F}$ )

The wraparound insulated resistance wire heaters supplied by the distribution panel in the pumphouse are checked to verify that they are turned on and operating properly. This is not necessary during warm weather when there is no danger of the coolant freezing.

\section{Health Physics Surveillance}

- Radiation and contamination survey-Weekly

Radiological surveys are conducted to identify which areas in the building are safe to enter without protective clothing and which contain radioactive contamination. The radiological surveys are done in accordance with RPP-110, the ORNL Radiological Control Policy, the ORNL Radiological Protection Procedure Manual, and 10 CFR Part 835 Occupational Radiation Protection.

Resource Requirement: 55 work-hours 
P\&E Division Programmed Maintenance

- Valve inspection-Every 2 years

Every 2 years, a valve inspection (at the SE comer of the building) is performed by P\&E personnel. This activity includes lubricating valve systems.

Rescurce Requirement: 1 work-hour

- GE exhaust fan inspection-Semiannually

A semiannual GE exhaust fan inspection is performed by P\&E personnel. This includes lubricating motor bearings, cleaning the motor housing, blades, and louvers.

Resource Requirement: 2 work-hours

- Nash-Hytor compressor inspection-Semiannually

A semiannual Nash-Hytor compressor inspection is performed by P\&E personnel. This activity includes lubricating the motor bearings; checking the shaft coupling and pin; lubricating the compressor shaft bearing; checking the packing for leaks; disassembling and cleaning Fisher valve; checking the mechanical seals for leaks; checking the Fisher valve A-78; checking the Fisher regulator A-3051; checking and cleaning the strainer; checking the orifice at the separator; and checking and adjusting the rotor cone clearance.

Resource Requirement: 2.75 work-hours

- Dryer Trinity Heat-Les N-unit inspection-Semiannually

A semiannual Dryer Trinity Heat-Les N-unit inspection is performed by P\&E personnel. This activity includes checking and cleaning the pilot solenoid valves, checking and cleaning the check-valves, checking and cleaning the pilot OPT inlet and purge, checking the pilot air in-line filter, checking the purge flow indicator, checking the chamber pressure gage, checking the moisture indicator, checking the condition and amount of desiccant, and checking the electrical components.

Resource Requirement: 2 work-hours

- Aurora pump—fill \& pressure pump inspection—Semiannually

A semiannual Aurora pump-fill \& pressure pump inspection is performed by P\&E personnel. This activity includes checking that the motor bearings are sealed, lubricating the pump shaft bearings, lubricating the valve stems, and checking the shaft coupling and pin.

Resource Requirement: 1.3 work-hours

- Electrical transformers and control units inspection - Every 4 months

An electrical transformers and control units inspection is performed every 4 months by $P \& E$ personnel. This activity includes inspecting, cleaning, checking operation, and adjusting the controls, switches, and transformers.

Resource Requirement: 6 work-hours 
- Aurora pump-shim pump inspection-Quarterly

Every 3 months, an Aurora pump-shim pump inspection is performed by P\&E personnel. This activity includes checking to ensure that the bearings are sealed, checking the shaft coupling and pin, lubricating the pump shaft bearings, checking and adjusting the packing, lubricating the valve stems, checking the Cuno Auto-Klean filter, turning the filter handle a full turn, and checking the Foxboro regulator.

Resource Requirement: 2.4 work-hours

- Aurora pump-emergency pump inspection-Semiannually

A semiannual Aurora pump-emergency pump inspection is performed by $P \& E$ personnel. This activity includes checking that the motor bearings are sealed, checking the shaft coupling and pin, lubricating the pump shaft bearings, lubricating the valve stems, and inspecting and replacing the brushes.

Resource Requirement: 1.2 work-hours

- Aurora pump-main circulating pump inspection-Quarterly

An Aurora pump - main circulating pump inspection is performed every 3 months by P\&E personnel. This activity includes checking to ensure that the motor bearings are sealed; lubricating the shaft coupling; lubricating the pump shaft bearings; checking the mechanical seals for leaks; lubricating the valve stems; checking the diaphragm valve and packing; checking the gauges, SWS, solenoid valves, and Moore valve; positioning the link; and checking the Black, Sivallas, and Bryson valves.

Resource Requirement: 8 work-hours

- Cold water level control tank inspection-Annually

An annual cold water level control tank inspection is performed by P\&E personnel. This activity includes checking the component gauges, valves, and the Magnetrol water level switches.

Resource Requirement: 0.5 work-hour

- Chromalox heater inspection-Annually

An annual Chromalox heater inspection is performed by P\&E personnel. This activity includes lubricating the motor bearings; checking the hangers, supports, hardware, and electrical components; and cleaning the fan, coil, louvers, and motor.

Resource Requirement: 2 work-hours

- Sliding hanger-type doors inspection-Every 5 Years

Every 5 years, a sliding hanger-type doors inspection is performed by P\&E personnel. This activity includes lubricating the track and the rollers.

Resource Requirement: 0.2 work-hour

- Aurora pump-demineralizer unit inspection-Quarterly

Every 3 months, an Aurora pump-demineralizer unit inspection is performed by P\&E personnel. This activity includes checking that the motor bearings are sealed, coating the coupling with oil, lubricating the pump shaft bearings, checking the mechanical seals for leaks, checking the Kates regulator, draining the Fulflo filter, checking the Honeycomb filter tubes, and changing when the pressure drop is $40 \mathrm{psi}$. 
Resource Requirement: 3 work-hours

- Chromalox heater inspection-Annually

An annual Chromalox heater inspection is performed by P\&E personnel. This activity includes lubricating the motor bearings; checking the hangers, supports, and hardware; checking the electrical components; and cleaning the fan, coil, louvers, and motor.

Resource Requirement: 2 work-hours

- Maintenance of roofs inspection-Annually

An annual inspection of the maintenance of the roofs is performed by P\&E personnel. This includes following guidelines of inspection as stated in the UCN 8953 form.

Resource Requirement: 1 work-hour

- Safety shower inspection-Monthly

A monthly safety shower inspection is performed by P\&E personnel. This activity includes checking the operation condition, reporting burned out lights, reporting the condition of the symbol, activating the eyewash, flushing the line a minimum of 3 minutes, and activating the shower to flush the line.

Resource Requirement: 12 work-hours

P\&E Division Nonroutine Maintenance

Non-routine maintenance activities are not scheduled but performed on an as-needed basis. Non-routine activities and their associated resource requirements performed in FY 1994 will be used to predict the levels of funding that should be set aside for such activities in the future.

Non-routine maintenance activities conducted by P\&E at the pumphouse in FY 1994 included various piping jobs, roof repairs, and the replacement of a glass door.

Resource Requirement: 120 work-hours

I\&C Division Surveillance and Maintenance

- Biannual calibrations-Every 2 years

The I\&C Division recalibrates the PT-137 and PT-138 pump pressure transmitters every 24 months. The TT-101 pump temperature monitor is also calibrated every 2 years.

Resource Requirement: 5 work-hours

- Annual calibrations-Annually

Calibrations are done on the FT-103 DP Transmitter and the PT-113 transmitter pressure monitor annually. The ACIM-128-1 and ACIM-128-2 analyzer resistivity meters, which measure the electrical resistivity of the water entering and leaving the demineralizer, are also annually recalibrated.

Resource Requirement: 8 work-hours 


\section{D.2.10. 7706 COOLER}

\section{Eacility Manager's Walk-through}

- Heaters-daily (if temperature $<50^{\circ}$ )

Each of the four heaters are checked to verify that they are turned on and operating. This check is unnecessary during warm weather when there is no danger of the water in the cooler freezing.

\section{Health Physics Surveillance}

- Radiation surveys-Annually

Radiological surveys are conducted to identify which areas in the building are safe to enter without protective clothing and which contain radioactive contamination. The radiological surveys are done in accordance with RPP-110, the ORNL Radiological Control Policy, the ORNL Radiological Protection Procedure Manual, and 10 CFR Part 835 Occupational Radiation Protection. Resource Requirement: 1 work-hour.

\section{P\&E Division Programmed Maintenance}

- Electrical switchgear units inspection-Every 4 years

An electrical switchgear units inspection is performed every 4 years by P\&E personnel. This activity includes inspecting, cleaning, checking the operation, and adjusting the motor control switchgear, fan-heat exchanger No. 1, and fan-heat exchanger No. 2.

Resource Requirement: 3 work-hours

- Heat exchanger Trane No. 1, Phil Drive inspection-Semiannually

A heat exchanger Trane No. 1, Phil Drive inspection is performed semiannually by P\&E personnel. This activity includes lubricating the motor bearings, checking the couplings and pins, checking the gearcase oil level, draining, flushing, and refilling the gearcase, lubricating the main drive shaft bearings, and lubricating the fan blade bearings. For Blades Hartzell, this activity includes checking the fan nuts, bolts, and screws; checking the blade pitch and controls; checking the air lines for leaks; checking the motor, fan, and gears for unusual noises and oil leaks; disassembling the power cylinder; cleaning and oiling the felt wiper ring on the piston; and cleaning and oiling the interior of the cylinder.

Resource Requirement: 6.9 work-hours

- Heat exchanger Trane No. 2, Phil Drive inspection-Semiannually

A heat exchanger Trane No. 2, Phil Drive inspection is performed semiannually by P\&E personnel. This activity includes lubricating the motor bearings; checking the couplings and pins; checking the gearcase oil level; draining, flushing, and refilling the gearcase; lubricating the main drive shaft bearings; and lubricating the fan blade bearings. For Blades Hartzell, this activity includes checking the fan nuts, bolts, and screws; checking the blade pitch and controls; checking the air lines for leaks; checking the motor, fan, and gears for unusual noises and oil leaks; disassembling the power cylinder; cleaning and oiling the felt wiper ring on the piston; and cleaning and oiling the interior of the cylinder.

Resource Requirement: 6.9 work-hours 
- Chromalox heaters inspection-Annually

An annual Chromalox heater inspection is performed by P\&E personnel. This activity includes lubricating the motor bearings; checking the hangers, supports, and hardware; checking the electrical components; and cleaning the fan, coil, louvers, and motor.

Resource Requirement: 4 work-hours

- Inspection of damper assembly inside cooling tower-Semiannually

A semiannual damper assembly inside the cooling tower inspection is performed by P\&E personnel. This activity includes lubricating the linkage and damper bearings, checking the operation of the air cylinders, inspecting the bellows, and checking for air line leaks.

Resource Requirement: 0.75 work-hour

- Damper assembly on top of the cooling tower inspection-Semiannually

A semiannual damper assembly inside the cooling tower inspection is performed by P\&E personnel. This activity includes lubricating the linkage and damper bearings, checking the operation of the air cylinders, and checking the Grinnell spring hangers.

Resource Requirement: 0.75 work-hour

\section{P\&EDivision Nonroutine Maintenance}

Non-routine maintenance activities are not scheduled but performed on an as-needed basis. Non-routine activities and their associated resource requirements performed in FY 1994 will be used to predict the levels of funding that should be set aside for such activities in the future.

Non-routine maintenance items in FY 1994 included the installation of a new hasp on the south door for locking purposes and repairs to the south heat exchanger.

Resource Requirement: 8 work-hours

I\&C Division Surveillance and Maintenance

The I\&C Division has no routine surveillance activities scheduled at this facility.

\section{D.2.11. 7707 BATTERY HOUSE}

\section{Eacility Manager's Walk-through}

- 120-volt battery charger fan-Daily

The fan for the battery charger is checked to verify that it is turned on and operating.

- 120-volt battery charger-Daily

The voltage across the battery charger and the current flowing through it are measured. Both of these values are recorded on the daily check list. 
- Control current-Daily

The control current is measured and recorded on the daily check list.

- Lead-acid batteries-Daily

The batteries are examined to verifty that the water level is normal and excessive bubbling is not occuring.

- Exhaust fans-Daily

Both the exhaust fan in the charger room and the exhaust fan in the battery room are checked to verify that they are turned on and operating.

Health Physics Surveillance

- Radiation surveys-Annually

Radiological surveys are conducted to identify which areas in the building are safe to enter without protective clothing and which contain radioactive contamination. The radiological surveys are done in accordance with RPP-110, the ORNL Radiological Control Policy, the ORNL Radiological Protection Procedure Manual, and 10 CFR Part 835 Occupational Radiation Protection. Resource Requirement: 1 work-hour

\section{P\&EDivision Programmed Maintenance}

- Battery TSF backup power supply inspection-Quarterly

A battery TSF backup power supply inspection is performed every 3 months by P\&E personnel. This activity includes cleaning and checking the battery tops and connector, and checking the water level. Resource Requirement: 22 work-hours

- Chromalox heater and IGL exhaust fan inspection - Annually

An annual Chromalox heater and IGL exhaust fan inspection is performed by P\&E personnel. This activity includes lubricating motor bearings, checking the operation, and cleaning the unit.

Resource Requirement: 6 work-hours

- Maintenance of roofs inspection-Annually

An annual inspection of the maintenance of the roofs is performed by P\&E personnel. This includes following guidelines of inspection as stated in the UCN 8953 form.

Resource Requirement: 1 work-hour 
- Safety shower inspection-Monthly

A monthly safety shower inspection is performed by P\&E personnel. This activity includes checking the operation condition, reporting burned out lights, reporting the condition of the symbol, activating the eyewash, flushing the line a minimum of 3 minutes, and activating the shower to flush the line.

Resource Requirement: 12 work-hours

P\&E Division Nonroutine Maintenance

Non-routine maintenance activities are not scheduled but performed on an as-needed basis. Non-routine activities and their associated resource requirements performed in FY 1994 will be used to predict the levels of funding that should be set aside for such activities in the future.

In FY 1994, nonroutine maintenance activities consisted of the replacement and removal of batteries and the reinsulation of water piping.

Resource Requirement: 71 work-hours

I\&C Division Surveillance and Maintenance

The I\&C Division has no routine surveillance activities scheduled at this facility.

\section{D.2.12. 7708 SHIELDING STORAGE (BUTLER BUILDING)}

Eacility Manager's Walk-through

No routine surveillance by the facility manager is scheduled at this facility.

Health Physics Surveillance

- Radiation surveys-Monthly

Radiological surveys are conducted to identify which areas in the building are safe to enter without protective clothing and which contain radioactive contamination. The radiological surveys are done in accordance with RPP-110, the ORNL Radiological Control Policy, the ORNL Radiological Protection Procedure Manual, and 10 CFR Part 835, "Occupational Radiation Protection." Resource Requirement: 65 work-hours.

\section{P\&E Division Programmed Maintenance}

- Maintenance of roofs inspection-Annually

An annual inspection of the maintenance of the roofs is performed by $P \& E$ personnel. This includes following guidelines of inspection as stated in the UCN 8953 form.

Resource Requirement: 4 work-hours 
P\&E Division Nonroutine Maintenance

Non-routine maintenance activities are not scheduled but performed on an as-needed basis. Non-routine activities and their associated resource requirements performed in FY 1994 will be used to predict the levels of funding that should be set aside for such activities in the future.

Non-routine maintenance items in FY 1994 involved setting drums of uranium oxide fuel pellets on pallets, banding the drums, and loading them aboard trucks for shipment to the Y-12 Plant.

Resource Requirement: 67 work-hours

I\&C Division Surveillance and Maintenance

The I\&C Division has no routine surveillance activities scheduled at this facility.

\section{D.2.13. 7716 FILTER HOUSE-MAIN POOL}

Eacility Manager's Walk-through

No routine surveillance by the facility manager is scheduled at this facility.

Health Physics Surveillance

- Radiation surveys-Annually

Radiological surveys are conducted to identify which areas in the building are safe to enter without protective clothing and which contain radioactive contamination. The radiological surveys are done in accordance with RPP-110, the ORNL Radiological Control Policy, the ORNL Radiological Protection Procedure Manual, and 10 CFR Part 835, "Occupational Radiation Protection." Resource Requirement: 1 work-hour.

\section{P\&E Division Programmed Maintenance}

No routine maintenance by the P\&E Division is scheduled at this facility.

R\&EDivision Nonroutine Maintenance

No nonroutine maintenance was performed by the P\&E Division at this facility in FY 1994.

I\&C Division Surveillance and Maintenance

The I\&C Division has no routine surveillance activities scheduled at this facility.

\section{D.2.14. CIVIL DEFENSE FACILITY}

\section{Eacility Manager's Walk-through}

No routine surveillance by the facility manager is scheduled at this facility. 
Health Physics Surveillance

- Radiation surveys-Semiannually

Radiological surveys are conducted to identify which areas in the building are safe to enter without protective clothing and which contain radioactive contamination. The radiological surveys are done in accordance with RPP-110, the ORNL Radiological Control Policy, the ORNL Radiological Protection Procedure Manual, and 10 CFR Part 835 Occupational Radiation Protection. Resource Requirement: 1 work-hour

\section{P\&E Division Programmed Maintenance}

No routine maintenance by the P\&E Division is scheduled at this facility.

\section{P\&EDivision Nonroutine Maintenance}

No nonroutine maintenance was performed by the P\&E Division at this facility in FY 1994.

I\&C Division Surveillance and Maintenance

The I\&C Division has no routine surveillance activities scheduled at this facility.

\section{D.2.15. BONEYARD}

\section{Eacility Manager's Walk-through}

No routine surveillance by the facility manager is scheduled at this facility.

\section{Health Physics Surveillance}

- Radiological surveys-Monthly

Radiological surveys are conducted to identify which areas in the building are safe to enter without protective clothing and which contain radioactive contamination. The radiological surveys are done in accordance with RPP-110, the ORNL Radiological Control Policy, the ORNL Radiological Protection Procedure Manual, and 10 CFR Part 835 Occupational Radiation Protection. Resource requirement: 95 work-hours.

\section{P\&E Division Programmed Maintenance}

No routine maintenance by the P\&E Division is scheduled at this facility.

\section{P\&E Division Nonroutine Maintenance}

Non-routine maintenance activities are not scheduled but performed on an as-needed basis. Non-routine activities and their associated resource requirements performed in FY 1994 will be used to predict the levels of funding that should be set aside for such activities in the future. Non-routine maintenance activites in FY 1994 included cutting, dismantling, and disposing of items in the boneyard. 


\section{D-34}

Resource Requirement: 124 work-hours

I\&C Division Surveillance and Maintenance

The I\&C Division has no routine surveillance activities scheduled at this facility. 


\section{D.3. 3010 BULK SHIELDING REACTOR FACILITY}

The following surveillance and maintenance activities are performed in Building 3010.

- Facility Manager inspection-As needed

Surveillance by the Facility Manager/Maintenance Coordinator is conducted on a level-of-effort basis. This surveillance consists of visual and/or records inspection of the BSF. Also, planning, scheduling and oversight of repair activities is conducted on a level-of-effort basis.

Resource Requirement: 1040 work-hours

- Research Reactor Division (RRD) surveillance-As needed

Facility operational surveillance by RRD personnel is conducted at regular intervals. The daily activities include the following: check special instruction clipboard; check all doors leading to pool area and control room; verify pool level is maintained at 4 to 5 in.; record level on clipboard at southeast comer of pool; verify that the skimmer system and CAM's and monitors are operating properly; verify cutie pie and survey meters are in the proper location; verify that pool room roof fan is off; verify that the hand cranks on reactor carnage, reactor bridge, and instrument bridge are chained and locked; check water level in overflow bottle on east $\mathrm{D}_{2} \mathrm{O}$ tank; inspect the off-gas port holes to ensure that the $\mathrm{D}_{2} \mathrm{O}$ overflow bottle is unobstructed; and check color on $\mathrm{D}_{2} \mathrm{O}$ overflow bottle off-gas hood drienite. If the color is pink, change drienite (weekly); ensure that the air pressure on core DP cell housing is maintained 8 psi-10 psi; verify that the overhead crane and mobile catwalk bridge electrical is locked and in the "off" position when not in use; verify that the fuel-handling tools for the BSR and PCA are located in place; verify that the experiments checked and services are completed; record the pool room negative pressures from the gauges located on the northwest and southeast walls; check control room portable emergency lights; check control room emergency lights "bright" (weekly); check pool room emergency lights (dim); verify that the $\mathrm{N}_{2}$ cylinder for evaction horn is in service with a pressure $>1000$ psi; check, record, and properly disposed of all bagged waste; check evacuation package (weekly), record skimmer filter inlet and exit pressures on a clipboard located at the SW comer of pool (weekly); test the control room smoke detector (weekly); and conduct area inspection that includes core, pumps, fans, motors (log abnormalities).

Resource Requirements: 507 work-hours

Below is a list of equipment and their Preventive Maintenance activities performed by P\&E Division. Also included is a brief description of some of the activities performed on the equipment listed.

- Continuous air monitors-Every 4 months

The motor bearings, blower shaft bearings, etc., are lubricated by $P \& E$ personnel. They also check belts, clean the motor, and check the gearcase and electrical components. These activities are performed once every 4 months.

Resource Requirement: 24 work-hours 


\section{D-36}

- Air-handling units (7)-Annually

The belts' wear, tension, and alignment are checked by personnel. The filters are changed as required. Flexible duct connections and all automatic controls are also checked. The strainer and motorized valve are blown out. The motor, fan, and pan are checked and cleaned of debris.

Resource Requirement: 189 work-hours

- Emergency exit and safety lights-Monthly

The lights are checked and replaced, as required.

Resource Requirement: 8.5 work-hours

- Building electrical switchgear maintenance-Every 4 years

The electrical switch gears are inspected throughout the building. The switch gears are checked for signs of overheating. The operation of access doors, safety latches, and wire connections are inspected to ensure that they are working properly. The panel interior is cleaned and the unused open knockouts are plugged.

Resource Requirement: 6 work-hours

- Exhaust fan-Annually

The motor and fan shaft bearings are lubricated by P\&E. They also checked the belts' wear, tension, and alignment. The belts and the flexible duct connection are checked.

Resource Requirement: 8 work-hours

- Recirculating pump-Every 2 years

The portable recirculating pump is removed and inspected.

Resource Requirement: 0.5 work-hour

- Bridge Trolley Detroit-Annually

The motor bearings, cross shaft bearings, wheel shaft bearings, and track wheel gears are lubricated by P\&E personnel. The motor, brake shaft couplings, and gearcase oil level are also checked. The feed rail connectors, collectors, electrical components, and mechanical components are checked and cleaned if necessary.

Resource Requirement: 10 work-hours

- Industrial 7-1/2 ton crane-Annually

The motor bearings, hoisting cable, blocking pin, drum shaft bearings, gearcase oil level, hoisting brake, track supports, and joints are lubricated by P\&E personnel. The electrical components are also checked and cleaned.

Resource Requirements: 18 work-hours 
- Swinging door-Annually

The control linkage and hinges are lubricated.

Resource Requirement: 1.2 work-hours

- Unit heaters-Every 2 years

The motor bearings, steam trap operation, piping insulation condition, and electrical components are checked. The strainer is blown out. The fan coil, louvers, and motor are cleaned.

Resource Requirement:16 work-hours

- Valve P.R. (supports cooling water system)-Annually

Lubricate valve stems; check for leaks; check insulation, main valve operation, pilot valve operation, and by-pass valve; and clean dirt leg.

Resource Requirement: 4 work-hours

- Pump Allis-Chalmers SW of pool area-Quarterly

The motor bearings are lubricated every 3 months. The pump shaft bearings are lubricated every 6 months. The valve stems are lubricated every 2 years. The shaft couplings are checked every 6 months. The packing is checked and repacked, if required, every 6 months. The oil reservoir is drained, flushed and refilled every 2 years.

Resource Requirement: 3 work-hours

- Reactor pool bridge (N \& S units)-Every 2 years

The hand cranks, wheel bearings and cross shaft bearings are lubricated.

Resource Requirement: 0.5 work-hour

- Corded equipment inspection (lab and shop only)-Every 2 years

The power cords are inspected. Resource Requirement: I work-hour

- Transformer, 750KVA-Annually

Sample oil for dielectric acid and color; check for loose connections and tighten; check for overheating and voltage creep on insulating surfaces; check tank connections and fittings; measure and record winding resistance for each phase; check transformer disconnect contact resistance, insulation resistance and dielectric absorption; and clean exterior of transformer.

Resource Requirement: 4 work-hours

- Inspect floor tile-Annually

The floor tile is inspected once a year. Resource Requirement: 0.20 work-hour

- Maintenance of structures-Annually 


\section{D-38}

The structure is inspected and repaired if any deficiencies are found.

Resource requirement: 1 work-hour

- Maintenance of roof-Annually

The roof is inspected and repaired if any deficiencies are found.

Resource Requirement: 4 work-hours

- Paint interior of building-Every 5 years

The interior of the building is inspected and painted if required.

Resource requirement: 0.5 work-hour

The following activities are performed by I\&C Division.

- Monitoring instrumentation (5)-Quarterly

The control functions and set point alarms of the monitoring instrumentation are tested to support the reactor fuel and low-level radiation sources stored in the pool.

Resource Requirements: 40 work-hours

- Meters (pH and resistivity)—Quarterly

Functional tests are performed on both the $\mathrm{pH}$ meters and the resistivity meter. These tests are performed once every 3 months for $\mathrm{pH}$ meters and once every 6 months for the resistivity meter.

Resource Requirement: 14 work-hours

- Pressure switches-Quarterly

The switches are tested to verify that they are accurately sensing changes in a transmitted signal and initiating an action (operate equipment or sound alarm).

Resource Requirement: 48 work-hours

- Differential pressure pneumatic transmitters-Quarterly

The transmitters are tested to ensure that they transmit a pneumatic signal to a remote location without a detrimental loss of accuracy or response in monitoring and/or controlling a process.

Resource Requirement: 36 work-hours

- Probe liquid level-Quarterly

A functional test is performed on the liquid level to ensure that it accurately measures the water level at the predetermined range.

Resource Requirement: 8 work-hours

- Recorders (electronic and pneumatic)-Quarterly

The recorders are tested to ensure that they accurately record and indicate signals from transmitting devices. 
Resource Requirement: 16 work-hours

\section{Health physics radiological surveillance-Various frequencies}

Radiological surveillance is conducted by RPD personnel. Radiological surveillance includes the following activities: weekly radiation field surveys, daily contamination surveys, level-of-effort surveillance and maintenance support, and level-of -effort radiation work permit support.

Resource Requirement: 380 work-hours

- Sampling and analysis-Weekly

Sampling and analysis of the water in pool is conducted by RRD and Analytical Chemistry.

Resource Requirement: 60 work-hours

- Safety inspection-Quarterly

A safety inspection is conducted by $R R D$ personnel. This inspection consists of a visual inspection to ensure the safety of all personnel working in or visiting the building.

Resource Requirement: 20 work-hours

- Fire inspection-Annually

The BSF fire protection equipment is inspected by Laboratory Protection personnel. This inspection includes several activities with different frequencies. The evacuation horn is tested bimonthly. The following systems or equipment are inspected and tested annually: the alarm system, the fire sprinkler system, and the fire extinguisher pressure. The extinguishers are repressurized as needed.

Resource requirement: Overhead

- High-efficiency particulate air (HEPA) filter inspection-Semiannually

A HEPA filter leak test is conducted semiannually by a combination of Quality Assessment and Inspection (QA\&I) personnel and RRD personnel.

Resource Requirement: 10 work-hours

- Crane inspection-As needed

A overhead crane inspection is conducted as needed by RRD and QA\&I personnel. This inspection is necessary before every use of the crane.

Resource Requirement: 8 work-hours

- HEPA filter replacement-As needed

The HEPA filters are replaced as needed with the help of RRD, P\&E, and CTD personnel. Resource Requirement: 50 work-hours

\section{D.3.1. BUILDING 3009}

- $R R D$ surveillance-Daily 
The sump pump is checked by RRD personnel for proper operation.

Resource Requirement 19.5 work-hours

- Paint exterior structure-Every 5 years

The exterior structure is inspected and painted if required by P\&E personnel.

Resource Requirement: 0.2 work-hour

- Health physics radiological surveillance-Various frequencies

Radiological surveillance is conducted by RPD personnel. Radiological surveillance includes the following activities: weekly contamination surveys, level-of-effort surveillance and maintenance support, and weekly radiation work permit support.

Resource Requirement: 65 work-hours

\section{D.3.2. BUILDING 3117}

- RRD surveillance-Various frequencies

RRD personnel add tower treatment and run secondary system for a minimum of 2 hours .This activity is performed biweekly. Also, if the outside temperature falls below 35 degrees, the steam tracing is turned on. The safety showers are checked weekly.

Resource Requirement: 58.5 work-hours

- Health physics radiological surveillance-Annually

Radiological surveillance is conducted by RPD personnel. Radiological surveillance includes the following activities: annual contamination surveys, level-of-effort surveillance and maintenance support, and level-of -effort radiation work permit support.

Resource Requirement: 8.5 work-hours

- Building electrical switchgear maintenance-Every 4 years

The electrical switch gears are inspected throughout the building by P\&E. The switch gears are checked for signs of overheating. The operation of access door and safety latch and wire connections are inspected to ensure they are working property. The panel interior is clean and the unused open knockouts are plugged.

Resource Requirement: 0.5 work-hours

- Centrifugal pumps south-Semiannually

The upper and lower motor bearings are lubricated once a year. The pump shaft bearings are lubricated every 6 months. The packing is checked and repacked if required every year. The anchor bolts are checked every 6 months. The electrical components are checked once a year.

Resource Requirement: 1.5 work-hours

- Centrifugal pump north-Semiannually 
The motor bearings are lubricated every 3 years. The pump shaft bearings are lubricated every 6 months. The packing is checked and repacked, if required, every year. The anchor bolts are checked every 3 years. Resource Requirement: 1.5 work-hours

- Cooling tower fan north-Annually

The motor bearings, shaft bearings, flow control valves, and stems are lubricated every year. P\&E checked each of the following: shaft couplings; operation of the motor, fan, and gear reducer; water level in basin; basin screens for clogging; blow-down control, float valve operation, and electrical components. They also performed chemical treatment. Half of the fan bolts are removed and inspected.

Resource Requirement: 4 work-hours

\section{- Cooling tower fan south-Every 2 years}

The motor bearings, shaft bearings, and ball float valve are lubricated by P\&E personnel. They also check shaft couplings, gearducer oil level, operation of motor fan gearducer, and electrical components. Resource Requirement: 2 work-hours

- Safety shower-Annually

The operating condition of safety shower is checked. The shower is activated and the line is flushed. Also, P\&E personnel report any burned out lights discovered during this activity.

Resource Requirement: 3.66 work-hours

- Fire inspection-Annually

The BSF fire protection equipment is inspected by Laboratory Protection personnel. These systems include the alarm system and the fire sprinkler system.

Resource Requirement: Overhead

\section{D.3.3. BUILDING 3119}

- RRD surveillance - Various frequencies

RRD personnel $\log$ the $\mathrm{pH}$ and resistance on the demineralizer inlet and exit daily. They also record demineralizer flow rate daily. The water counts on demineralizer inlet are logged weekly. They turn on building heat and the primary flow dp cell hutch heater if outside temperature falls to $35^{\circ} \mathrm{F}$ or below. The safety shower is checked weekly.

Resource Requirement: 97.5 work-hours

- Health physics radiological surveillance-Monthly

Radiological surveillance is conducted by RPD personnel. Radiological surveillance includes the following activities: monthly contamination and radiological field surveys, level-of-effort surveillance and maintenance support, and level-of-effort radiation work permit support.

Resource Requirement: 64 work-hours

- Building electrical switchgear maintenance-Every 4 years 
The electrical switchgears are inspected throughout the Building by P\&E. The switch gears are checked for signs of overheating. The operation of access door and safety latch and wire connections are inspected to ensure they are working properly. The panel interior is clean and the unused open knockouts are plugged.

Resource Requirement: 2 work-hours

- Steam heater-Every 4 years

The motor, fan, coil, and louvers are cleaned by P\&E personnel. They also checked the steam trap operation, piping insulation condition, electrical components and hanger supports.

Resource requirement: 2 work-hours

- Pumps (2)-Every 2 years

The motor bearings, valve stems, and pump shaft bearings are lubricated by P\&E personnel every 6 months. Shaft couplings and motor pump are checked once a year. The pump's motor is cleaned if required.

Resource Requirement: 3 work-hours

- Electrical control panel-Annually

The panel lights and switch handles are checked by P\&E personnel. The switch handles are tightened if they are discovered to be loose.

Resource Requirement: 0.2 work-hour

- Air control valve (controls water flow)-Every 2 years

The valve and air line connection are checked for leaks by P\&E. Also, the valve packing is checked and repacked if required. The valve stem is checked and cleaned if necessary.

Resource Requirement: 2 work-hours

- Corded equipment inspection-Every 2 years

The equipment is checked in accordance with QA-PE- 18/M.3.15, power cords only.

Resource Requirement: 0.1 work-hour

- Maintenance of roof-Annually

The roof is inspected and repaired if the roof is discovered to be defective.

Resource Requirement: 1 work-hour

- Safety shower-Quarterly

The operating condition of safety shower is checked. The shower is activated and the line is flushed. Also, P\&E personnel report any burned out lights discovered during this activity.

Resource Requirement: 2.67 work-hours

- Differential pressure pneumatic transmitters-Quarterly 
The transmitters are tested by I\&C to ensure that they transmit a pneumatic signal to a remote location without a detrimental loss of accuracy or response in monitoring and/or controlling a process.

Resource Requirement:16 work-hours

\section{D.3.4. BUILDING 3098}

- RRD surveillance-Weekly

RRD personnel records the cell ventilation filter dp readings weekly.

Resource Requirement: 19.5 work-hours

- Paint exterior structure-Every 4 years

P\&E personnel inspect exterior structure and paint if required.

Resource Requirement: 0.2 work-hour

- Health physics radiological surveillance-Monthly

Radiological surveillance is conducted by RPD personnel. Radiological surveillance includes the following activities: monthly contamination and radiological field surveys, level-of-effort surveillance and maintenance support, and level-of-effort radiation work permit support.

Resource Requirement: 119 work-hours

- HEPA filter inspection-Semiannually

A HEPA filter leak test is conducted semiannually by a combination of QA\&I personnel and RRD personnel.

Resource Requirement: 5 work-hours

\section{D.3.5. BUILDING 3101}

- Health physics radiological surveillance-Annually

Radiological surveillance is conducted by RPD personnel. Radiological surveillance includes the following activities: annual contamination surveys, level-of-effort surveillance and maintenance support, and level-of-effort radiation work permit support.

Resource Requirement: 2 work-hours

\section{D.3.6. BUILDING 3004}

- RRD surveillance-Daily

RRD personnel record the $\mathrm{pH}$ and resistivity of the demineralizer water daily. They also record demineralized water storage tank level and flow level daily.

Resource Requirement: 78 work-hours 
- Fire inspection-Annually

The BSF fire protection equipment is inspected by Laboratory Protection personnel. This inspection includes several activities with different frequencies. The evacuation hom is tested bimonthly. The following systems or equipment are inspected and tested annually: alarm system, fire sprinkler system, and fire extinguisher pressure. The extinguishers are repressurized as needed.

Resource requirement: Overhead

- Health physics radiological surveillance-Various frequencies

Radiological surveillance is conducted by RPD personnel. Radiological surveillance includes the following activities: weekly radiation field surveys, daily contamination surveys, level-of-effort surveillance and maintenance support, and level-of-effort radiation work permit support.

Resource Requirement: 192 work-hours

- Unit heaters-Every 2 years

The motor bearings, steam trap operation, piping insulation condition, and electrical components are checked. The strainer is blown out and the fan coil, louvers, and motor are cleaned.

Resource Requirement:16 work-hours

- Valve P.R-Annually

Lubricate valve stems; check for leaks; check insulation, main valve operation, pilot valve operation, and by-pass valve; and clean dirt leg.

Resource Requirement: 4 work-hours

- Corded equipment inspection-Every 2 years .

The equipment is checked in accordance with QA-PE-18/M.3.15 (power cords only).

Resource Requirement: 0.5 work-hour

- Maintenance of roof-Annually

The roof is inspected and repaired if the roof is discovered to be defective.

Resource Requirement: 4 work-hours

- Safety shower-Quarterly

The operating condition of safety shower is checked. The shower is activated and the line is flushed. Also, P\&E personnel report any burned out lights discovered during this activity.

Resource Requirement: 2.67 work-hours

\section{D.3.7. 3004A CAUSTIC TANK}

There are no S\&M activities being performed at this location. 


\section{D.3.8. 3004B CAUSTIC TANK}

There are no S\&M activities being performed at this location.

\section{D.3.9. 3004C CAUSTIC TANK}

There are no S\&M activities being performed at this location.

\section{D.3.10. 3004D NITRIC ACID TANK}

There are no S\&M activities being performed at this location.

\section{D.3.11. 3004E NITRIC ACID TANK}

There are no S\&M activities being performed at this location.

\section{D.3.12. 3004F NITRIC ACID TANK}

There are no S\&M activities being performed at this location.

\section{D.3.13. 3004H NITRIC ACID TANK}

There are no S\&M activities being performed at this location.

\section{D.3.14. 3117A SULFURIC ACID TANK}

There are no S\&M activities being performed at this location.

\section{D.3.15. A-1204 LIQUID NITROGEN TANK}

There are no S\&M activities performed at this location.

\section{D.3.16. 13822 HELIUM TANK}

There are no activities being performed at this location.

\section{D.3.17. BUILDING 3088}

There are no S\&M activities being performed at this location. 


\section{D.4. 3019B HIGH RADIATION LEVEL ANALYTICAL FACILITY}

The following surveillance and maintenance activities are performed for the maintenance of an adequate safety envelope around Building 3019B.

- Facility Manager inspection-As needed

Surveillance by the Facility Manager is conducted on a level-of-effort basis. This surveillance consists of a visual and/or records inspection of Building 3019B.

Resource Requirement: 400 work-hours

- Chemical Technology Division (CTD) surveillance-As needed

Facility operational surveillance by CTD personnel is conducted at regular intervals. The length of the intervals depends on the system under surveillance and may vary from daily to quarterly. The following building systems are included in this surveillance: building confinement integrity; cell areas, including the bonds over contaminated surfaces; and the building ventilation system, including the ventilation fans, High-Efficiency Particulate Air (HEPA) filters, and area pressure differentials.

Resource Requirement: 280 work-hours

- Radiological surveillance control-Weekly

Radiological control oversight is performed weekly by CTD personnel. This activity consists of interaction with the Radiation Protection (RP) personnel who monitor the status of radiation protection in the building.

Resource Requirement: 280 work-hours

- Health physics radiological surveillance-Various frequencies

Radiological surveillance is conducted by RP personnel. Radiological surveillance includes the following activities: quarterly radiation field surveys, monthly and quarterly contamination surveys, level-of-effort surveillance and maintenance support, and level-of-effort radiation work permit support.

Resource Requirement: 700 work-hours

- Safety inspection-Annually

A safety inspection is conducted quarterly by CTD personnel. This inspection consists of a visual inspection to ensure the safety of all personnel working in or visiting the building.

Resource Requirement: 20 work-hours

- Fire protection inspection-Annually

The building is inspected for fire safety protection by Laboratory Protection personnel. This inspection includes several activities with different frequencies. The evacuation hom is tested bimonthly, and the structure of the building is examined for fire protection monthly. The following systems or equipment are inspected and tested annually: the alarm system, the fire sprinkler system, and the fire extinguisher 


\section{D-47}

pressure. The extinguishers are repressurized as needed. Because all these activities are performed under laboratory overhead funding, an estimate of the work-hours required was not obtained.

Resource Requirement: Undetermined

- HEPA filter inspection-Semiannually

A HEPA filter leak test is conducted semiannually by a combination of QA\&I personnel and CTD personnel.

Resource Requirement: 4 work-hours

- Crane inspection - As needed

An inspection of the overhead crane is conducted as needed by CTD personnel. This inspection is necessary before every use of the crane.

Resource Requirement: 8 work-hours

- Safeguards and security inspection-Annually

A routine security patrol is conducted in the building daily by Laboratory Protection personnel. Because this activity is funded out of overhead, an estimate of its resource requirement was not obtained.

Resource Requirement: Undetermined

- Alarm inspections-Daily and quarterly

Supervisory alarm panel checks and tests are conducted daily and quarterly by CTD personnel.

Resource Requirement: 8 work-hours

- Emergency lighting inspection-Monthly

The emergency lighting is checked and tested monthly and annually by CTD and P\&E Division personnel. This is programmed maintenance.

Resource Requirement: 4 work-hours

- Oversight of maintenance activities-As needed

The planning, scheduling, and oversight of repair activities is conducted on a level-of-effort basis by CTD personnel.

Resource Requirement: 50 work-hours

- P\&E preventive maintenance-Annually, Semiannually, and Monthly

General maintenance and repair are conducted as required by P\&E personnel.

Resource Requirement: 250 work-hours

- HEPA filter replacement-As needed

The HEPA filters are replaced as needed with the help of CTD, P\&E, and RP personnel.

Resource Requirement: 110 work-hours 
- Radiation monitroing equipment-As needed

The calibration and maintenance of Health Physics equipment is conducted as required by I\&C and P\&E personnel.

Resource Requirement: 20 work-hours

- Instrument calibration-Annually

Instrumentation and controls calibration and maintenance is conducted annually by $I \& C$ personnel. Resource Requirement: 40 work-hours

- Heating system maintenance-As needed

The maintenance of the heating system is performed as required by P\&E personnel.

Resource Requirement: 40 work-hours

- Ventilation system maintenance-Weekly, monthly, and quarterly

The maintenance of the ventilation system is conducted by $P \& E$ and $I \& C$ personnel weekly, monthly, and quarterly, as identified in the programmed maintenance schedule for different activities.

Resource Requirement: 40 work-hours

- Low-level waste disposal-As needed

Radioactive waste disposal from maintenance activities is performed as required by CTD and RP personnel. These activities require approximately 60 work-hours annually.

Resource Requirement: 60 work-hours

- Hazardous material disposal-As needed

RCRA waste accumulation for maintenance activities is conducted by CTD personnel as needed.

Resource Requirement: 10 work-hours

- TSCA material and PCB disposal-As needed

TSCA and PCB waste handling for maintenance activities is conducted as required by CTD personnel. Resource Requirement: 10 work-hours 


\section{D.5. 7602 INTEGRATED PROCESS DEMONSTRATION FACILITY}

The following surveillance and maintenance activities are performed for the maintenance of an adequate safety envelope around Building 7602.

- Facility Manager oversight-Daily

The Facility Manager's time is required for the preparation of an Occurrence Report should that become necessary.

Resource Requirement: 264 work-hours

- Facility surveillance-Daily, biweekly, and weekly

Facility surveillance of Building 7602 is conducted at regular intervals by Robotics and Process Systems Division (RPSD) personnel. The individual activities included in the facility surveillance are the following: a daily visual inspection of the building exterior, biweekly visual inspections of the process area, and weekly inspections of the HEPA filters and the pressure drops.

Resource Requirement: 176 work-hours

- Radiological control oversight-As needed

Radiological control oversight is performed as required by RPSD personnel. This activity consists of interaction with RP personnel who monitor the status of radiation protection in the building.

Resource Requirement: 176 work-hours

- Radiological surveillance-As needed

Radiological surveillance is conducted by RP personnel as required. Radiological surveillance includes the following activities: radiation exposure surveys, contamination surveys, surveillance and maintenance support, and radiation work permit support.

Resource Requirement: 468 work-hours

- Safety inspection-Annually

A safety inspection is conducted semiannually by RPSD personnel. This inspection consists of a visual inspection to ensure the safety of all personnel working in or visiting the building.

Resource Requirement: 12 work-hours

- Fire protection inspection-Various frequencies

The building is inspected for fire safety protection by Laboratory Protection personnel. This inspection includes several activities with different frequencies. The evacuation horn is tested bimonthly. The following systems or equipment are inspected and tested annually: alarm system, fire sprinkler system, and fire extinguisher pressure. The extinguishers are repressurized as needed. Because all of these activities are performed under laboratory overhead funding, an estimate of the person hours required was not obtained.

Resource Requirement: Undetermined 


\section{D-50}

- HEPA filter inspection-Annually

A HEPA filter dioctylphthalate (DOP) test is conducted annually by a combination of RP, QA\&I, and RPSD personnel.

Resource Requirement: 4 work-hours

- Crane inspection-As needed

An inspection of the overhead crane is conducted as needed by RPSD personnel. This inspection is necessary before every use of the crane.

Resource Requirement: 12 work-hours

- Safeguards and security-Daily

A routine security patrol is conducted in the building daily by Laboratory Protection personnel. Because this activity is funded out of overhead, an estimate of its resource requirement was not obtained.

Resource Requirement: Undetermined

- Applied technology security-As needed

Security for applied technology is exercised by RPSD personnel as required.

Resource Requirement: 200 work-hours

- Alarm tests-Quarterly

Supervisory panel high-level alarm tests are conducted quarterly by RPSD personnel. The resource requirement for this activity is approximately 8 work-hours annually.

Resource Requirement: 8 work-hours

- Emergency lighting tests-Semiannually

The emergency lighting is tested semiannually by RPSD and P\&E personnel. This is programmed maintenance.

Resource Requirement: 8 work-hours

- P\&E Division routine maintenance-Monthly, semiannually, and annually

General maintenance and repairs are conducted as required by RPSD and P\&E personnel.

Resource Requirement: 200 work-hours

- HEPA filter replacement-As needed

The HEPA filters are replaced as needed with the help of P\&E and RP personnel.

Resource Requirement: 72 work-hours 
- Radiation protection equipment maintenance-As needed

The calibration, maintenance, and repair of Health Physics instrumentation is conducted by I\&C personnel.

Resource Requirement: 13 work-hours

- Heating system maintenance-As required

The maintenance of the heating system is performed as required by $P \& E$ personnel.

Resource Requirement: 53 work-hours

- Radioactive waste disposal-As required

Radioactive waste disposal from maintenance activities are performed as required by RPSD and RP personnel.

Resource Requirement: 53 work-hours

- Window air conditioning unit-Annually

The window air conditioning unit number 7602-00001 receives the following programmed maintenance by P\&E personnel. Every 3 months, the filter is checked and changed as needed. The operation of the air conditioner is checked annually.

Resource Requirement: 2 work-hours

- Trane air conditioner-Annually

Trane air conditioner No. 7602-00005 receives programmed maintenance by P\&E personnel. The following activities are performed annually: Freon and coils are checked; fan blades are checked; the pan is checked, cleaned, and drained; and electrical components are checked. In addition, filters are checked every 3 months, and the oil in the motor is checked every 6 months.

Resource Requirement: 6 work-hours.

- Singer air conditioner in High Bay West Area-Annually

Singer air conditioner No. 7602-00010 in the High Bay West Unit receives the following programmed maintenance by P\&E employees. The filters are checked and changed if necessary, and the operation is checked every 3 months. The belt is checked and the motor is lubricated every 6 months. The Freon, fan, coils, and drain are checked, and the thermostat and electrical components are checked annually. Resource Requirement: 27 work-hours.

- Singer air conditioner in High Bay East Area-Annually

Singer air conditioner No. 7602-00015 in the High Bay East Unit receives the following programmed maintenance by P\&E employees. The filters are checked and changed if necessary every 3 months. The belt is checked and the motor is lubricated every 6 months. The Freon, fan, coils, and drain are checked, and the thermostat and electrical components are checked annually.

Resource Requirement: 27 work-hours.

- G.E. heat pump-Annually 
The G.E. window-type heat pump number 7602-01005 receives the following programmed maintenance by P\&E personnel: the operation is checked and the filter is changed if necessary every 4 months and the motor is oiled annually

Resource Requirement: 2 work-hours.

- Fire alarms-Every 4 years

Fire alarm No. 7602-01010 receives programmed maintenance from P\&E personnel every 4 years. This maintenance includes checking the battery stock and replacing the rechargeable battery.

Resource Requirement: 1 work-hour.

- 7602 backflow preventer-Semiannually

The 7602 backflow preventer receives a QA\&I inspection by P\&E personnel every 6 months. Resource Requirement: 3 work-hours.

- McQuay air conditioner-Annually

McQuay air conditioner No. 7602-02005 in the Boiler Room receives the following programmed maintenance by P\&E employees: the filters are checked and changed if necessary, and the operation of the unit is checked every 3 months; the belt is checked; the drain pan and line are checked and cleaned; and the bearings and motor are lubricated every 6 months. The electrical components are checked annually.

Resource Requirement: 10 work-hours.

- Ice machine-Quarterly

P\&E employees change the water filter on ice machine No. 7602-02010 every 3 months.

Resource Requirement: 1 work-hour.

- South hot water circulation pump-Semiannually

South hot water circulation pump No. 7602-02100 receives the following programmed maintenance by P\&E personnel at regular intervals: the mechanical seal is checked every 3 months and the shaft coupling is checked every 6 months. The following activities are performed annually: the motor bearings are sealed, the insulation condition is reported, the pump gutter and drain are checked, and the motor, pump, and base are cleaned.

Resource Requirement: 5 work-hours.

- Center hot water circulation pump-Semiannually

Center hot water circulation pump No. 7602-02105 receives the following programmed maintenance by P\&E personnel at regular intervals: the mechanical seal is checked every 3 months and the shaft coupling is checked every 6 months. The following activities are performed annually: the motor bearings are sealed, the insulation condition is reported, the pump gutter and drain are checked, and the motor, pump, and base are cleaned.

Resource Requirement: 5 work-hours.

- North hot water circulation pump - Semiannually 
North hot water circulation pump No. 7602-02110 receives the following programmed maintenance by P\&E personnel at regular intervals: the mechanical seal is checked every 3 months and the shaft coupling is checked every 6 months. The following activities are performed annually: the motor bearings are sealed; the insulation condition is reported; the pump gutter and drain are checked; and the motor, pump, and base are cleaned.

Resource Requirement: 5 work-hours.

\section{- Continental hot water boiler-Every 2 years}

The Continental hot water boiler receives the following programmed maintenance by $P \& E$ personnel at regular intervals: every 6 months, the blower belt is checked and adjusted, the moving parts of the motor are lubricated, the fuel oil filter is drained and turned, and the fuel oil pump and motor are cleaned and inspected; and the blower belts are replaced every 2 years. All other maintenance is done annually and includes the following activities: an internal and external inspection is conducted, the tubes and furnace firesides are cleaned and brushed, the oil burners and ignition probes are removed and cleaned, the burner door gaskets are replaced as needed, the hand caps are removed and washed down, and the relief valves are tested.

Resource Requirement: 42 work-hours.

- Exhaust fan-Annually

The exhaust fan on the South wall of the boiler room receives the following annual maintenance by P\&E personnel: the motor bearings are lubricated. The following components are checked: motor, fan, electrical components, hardware, hangers, and flex duct connectors. The motor, fan, and intake screen are cleaned.

Resource Requirement: 9 work-hours.

- Exhaust fan-Annually

An annual inspection of the exhaust fan on the South wall of the boiler room is performed by P\&E personnel. This activity includes conducting a visual inspection, cleaning the equipment, and replacing the motor.

Resource Requirement: 8 work-hours.

- F-14 waste pump-Semiannually

A biannual inspection of the F-14 waste pump is performed by $P \& E$ personnel. This activity includes checking the pump operation and checking for leaks.

Resource Requirement: 1 work-hour

- F-14 waste tank pit-Semiannually

A biannual inspection of the F-14 waste tank pit is performed by P\&E personnel. This includes cleaning the floor of the tank pit, cleaning the sump basin, and checking the operation of the pit sump pump. Resource Requirement: 4 work-hours

- Trane air conditioner-Annually 
An annual inspection of the Trane air conditioner on mezzanine A/C-002 is performed by P\&E personnel. This activity includes checking the Freon, electrical components, drain line, filters, and belt; replacing filters and belt as required; and blowing the drain line.

Resource Requirement: 9 work-hours

- Truck door-Every 2 years

The truck door on the East side receives an inspection every 2 years by P\&E personnel. This activity includes checking the operating condition, electrical components limit switches, slat guides, brakes, gear box, chain, and curtain to the roller bolts and providing necessary maintenance. Additionally, the motor, gear, guards, and covers are cleaned.

Resource Requirement: 3 work-hours

- West Westinghouse heater AK-9-Annually

The Westinghouse AK-9 heater is inspected annually by P\&E personnel. This activity includes checking for belt wear, tension, alignment, piping leaks, insulation condition, hangers, hardware, electric controls, pneumatic controls, and components. Additionally, moving parts are lubricated; the motor, unit, and louvers are cleaned; and the belt is replaced as needed.

Resource Requirement: 8 work-hours

- Center Westinghouse heater-Annually

The Westinghouse AK-10 heater is inspected annually by P\&E personnel. This activity includes checking for belt wear, tension, alignment, piping leaks, insulation condition, hangers, hardware, electric controls, pneumatic controls, and components. Additionally, moving parts are lubricated; the motor, unit, and louvers are cleaned; and the belt is replaced as needed.

Resource Requirement: 8 work-hours

- West Westinghouse heater AK-11-Annually

The Westinghouse AK-11 heater is inspected annually by P\&E personnel. This activity includes checking for belt wear, tension, alignment, piping leaks, insulation condition, hangers, hardware, electric controls, pneumatic controls, and components. Additionally, moving parts are lubricated; the motor, unit, and louvers are cleaned; and the belt is replaced as needed.

Resource Requirement: 8 work-hours

- Conco bridge crane inspection (Card 2)-Annually

An annual Conco bridge crane inspection is performed by P\&E personnel. This activity includes lubricating the pendant cable swing arm pivot bearings and the bridge, trolley, and hoist brake bearing linkage pins; checking the feedrail hangers; cleaning and checking the collectors and hangers; checking all the electrical components, relays, and connections; cleaning and clearing all the ladder landings and catwalks; wiping all the oil from these surfaces; checking all the guards and handrails; and lubricating and equalizing the sheaves and hood bearings. For the 5-ton auxiliary hoist, this activity includes checking the hoist gearcase oil level; draining, flushing, and refilling the hoist gearcase; checking the operation of the paddle and geared limit switches; lubricating the equalizing, block, and hook bearings; listening for a loud click as an indication of mechanical brake wear when operating at no load; checking 


\section{D-55}

the adjustment and wear of the solenoid brake operation; lubricating the motor bearings; checking and cleaning the brushes; brushing the rigging; and checking the slip rings.

Resource Requirement: 12 hours

\section{- Conco bridge crane inspection (Card 1)-Annually}

An annual Conco bridge crane inspection is performed by P\&E personnel. This activity includes lubricating the bridge wheel bearings, bridge wheel gears, pinion, and cross shaft bearings; cleaning the wheel gear drip pans; checking the cross shaft coupling bolts; lubricating the bridge drive motor; checking and cleaning the brushes and brush rigging; checking the slip rings; lubricating the motor shaft coupling; checking the bridge gearcase oil level; draining, flushing, and refilling the bridge gearcase; checking the gearcase shaft seal leaks; checking the adjustment and wear of the bridge brake operation; and checking the shaft mounting bolts, keys, and set screws. For the trolley, this activity includes lubricating the trolley wheel bearings and the trolley wheel gears and pinion; cleaning the wheel gear drip pans; lubricating the cross shaft bearing; checking the cross shaft coupling bolts; lubricating the trolley drive motor; checking and cleaning the brushes; brushing the rigging; checking the slip rings; lubricating the motor shaft coupling; checking the trolley gearcase oil level; draining, flushing, and refilling the trolley gearcase, checking the gearcase shaft seal leaks; checking the adjustment and wear of the trolley brake operation; checking the shaft mounting bolts and keys; and setting screws. For the 25-ton main hoist, this activity includes lubricating the drum pinion shaft bearings and the pinion and spur gear; cleaning the drum gear oil drip pan; lubricating the drum shaft bearings and main hoist drive motor; checking and cleaning the brushes; brushing the rigging; checking the slip rings; lubricating the motor and gear couplings; checking the hoist gearcase oil level; draining, flushing, and refilling the hoist gearcase; cleaning the magnetic drain plug; checking the hoist gear seal leakage and the adjustment and wear of the hoist brake operation; checking the shaft mounting bolts and keys; setting screws; checking the geared limit switch operation, roller chain, and sprockets; cleaning the roller chain with kerosene and relubing; and checking the operation of the paddle limit switch.

Resource Requirement: 12 hours

\section{- Conco bridge crane inspection-Quarterly}

A Conco bridge crane inspection is performed every 3 months by P\&E personnel. This activity includes visually inspecting the hoist, bridge and trolley.

Resource Requirement: 2 work-hours

- Truck door (east side, south) inspection-Every 2 years

A truck door inspection is performed every 2 years by P\&E personnel. This activity includes checking the slat-guide side clearance, and for loose or bent slat endlocks, tightening the mounting and guide bolts; checking the slat guide width and the curtain to the roller bolts; lubricating the slat guides and the motor bearings; draining, flushing, and refilling the gear box; checking and adjusting the roller chain tension; lubricating the roller chain; cleaning the chain with kerosene only and relubricating; checking the brake operation stroke, and if it is greater than a 7/8-in stroke, readjusting to 3/8-in. stroke; checking the brake lining and replacing it when the lining is wom to $1 / 32$ in.; checking the operational condition, limit switches, and electrical components; and cleaning the motor, gear, guards, and covers.

Resource Requirement: 3 work-hours

- Men's change room heat pump and carrier inspection-Annually 
A men's room heat pump and carrier inspection is performed annually by $P \& E$ personnel. For the change room coil unit, this activity includes cleaning or replacing the filter; lubricating the fan motor; checking the electric heater, cleaning the fan, coil, and pan; checking the operation unit and the operation controls; checking and cleaning the clear pan drain; and checking the hanger and supports. For the outside compressor unit, this activity includes lubricating the fan motor; cleaning the fan, coil, and pan; and checking the operation unit, operation controls, refrigerant charge, piping supports, and insulation. Resource Requirement: 9 work-hours

- Supervisory alarms test locations-Quarterly

P\&E personnel tested supervisory alarms in Building 7602 approximately 4 times per year. Resource Requirement: 2 work-hours

\section{- Exhaust fan AJ-26 (7602 roof)-Every 2 Years}

An exhaust fan AJ-26 inspection is performed every 2 years by P\&E personnel. This activity includes checking to ensure that the motor bearing is sealed; checking the belt wear, tension, and alignment; replacing belts; lubricating the fan shaft bearings; checking the flex duct connector; checking the pre-filter pressure drop, the HEPA filter pressure drop, and the electrical components; cleaning the motor and fan; and inspecting the sheet metal, hangers, braces, supports, paint, door gaskets, and fasteners. Resource Requirement: 4 work-hours

- Service building exhaust fan AJ-26-Semiannually

A semiannual service building exhaust fan inspection is performed by P\&E personnel. This activity includes checking the pneumatic damper operation.

Resource Requirement: 1 work-hour

- Trane package unit-Annually

An annual trane package unit inspection is performed by P\&E personnel. This activity includes checking and changing the filter as required; checking and replacing the belt as required; checking and cleaning the drain pan as required; checking and cleaning the coils, sight glass, and fan; lubricating the motors and bearings; and checking the electrical components.

Resource Requirement: 5 work-hours

- Corded equipment inspection (labs \& shops only)-Annually

A yearly inspection of corded equipment by P\&E personnel includes complete check of power cords in accord with QA procedure.

Resource Requirement: 1 work-hour

- Maintenance of roofs-Annually

A yearly inspection of roofs by P\&E personnel includes complete check for structural deterioration. Resource Requirement: 4 work-hours

- Safety showers-Quarterly 
Inspection by $P \& E$ personnel every 3 months includes checking operating condition of safety shower and eyewash in all locations, reporting condition of symbol, replacing burned out lights, activating eyewash and shower to flush line, and signing log locally.

Resource Requirement: 16 work-hours

\section{S\&M Summary}

All S\&M activities will be re-evaluated according to their current drivers and benefits. Many activities are subject to change in an attempt to reduce costs while always ensuring adequate safety and health issues are addressed and minimized. Additionally, as deactivation activities are performed, many requirements will no longer be necessary as a result of the activity. The overall goal is still to reduce S\&M costs to a minimum while retaining an adequate safety envelope at all times. As deactivation increases, S\&M should decrease. 
Appendix E

FY 1996

PLANNED MAJOR HIGHLIGHTS 
HIGH RANKING FACILITIES DEACTIVATION PROJECT FY 1996 PLANNED MAJOR DEACTIVATION HIGHLIGHTS

\section{Introduction to Planned Major Deactivation Highlights for FY 1996}

The following activities include conceptual estimates and best judgment schedules; they are not based on any detailed engineering analysis. For a summary of activities and projected costs and schedules, see Table 4.

- Patch roof of 3019B, high level analytical lab-End of second quarter

Patching the roof will eliminate cleanup of the facility by maintenance personnel after leakage due to lack of drains. The action also reduces the potential of contamination migration from hot cells as some leaks are adjacent to hot cell areas. This action will result in S\&M savings. Table 4 indicates the FY 1996 activities, conceptual cost estimates, and schedules for FY 1996 activities.

- Life cycle baseline-End of second quarter

The Life Cycle Baseline will provide the detailed schedules with milestones and cost estimates. The baselines will provide a budget plan that will be used to monitor progress and evaluate the project.

- Bulk Shielding Facility (BSF ) nuclear fuel removal alternatives evaluation-End of third quarter

- Tower Shielding Facility ( TSF ) nuclear fuel removal alternatives evaluation-End of fourth quarter

The nuclear fuel alternatives evaluations will review both on-site and off-site alternatives and recommend the best cost and schedule option for each site. This option will be used to project and plan future facility budgets and work plans.

- Uranyl nitrate removal from 7602 Process Demonstration Facility - End third quarter if all assumptions are met

Removal will also facilitate the transfer to EM-40.

- Remove and recycle lead at the TSF-End fourth quarter

The removal and recycle of lead will reduce the hazardous material inventory and reduce Resource Conservation and Recovery Act (RCRA) potential noncompliances at a later date. This will reduce possible future RCRA cost issues and will facilitate transfer to EM-40.

- Survey instrument towers at TSF-End fourth quarter

Surveying the towers in FY 1996 will support the removal of the towers in FY1997. The issue of the towers is the Yellow condition issued for the anchoring system used on similar towers that failed. Addressing the towers will show intent of safety concern and save possible negligent safety violation fines in the future. 
- Routine Deactivation

Routine deactivation activities will be miscellaneous activities such as transferrable contamination removal and fixed contamination bonding resulting from other deactivation or surveillance and maintenance activities.

Note: These activities are prioritized based on the best available information. 


\section{DISTRIBUTION}

1. L. V. Asplund

2. T. M. Bonine

3. T. W. Burwinkle

4. C. Clark, Jr.

5. K. Constant

6. R. B. Cook

7. J. G. Harris

8-13. J. B. Harstin

14. J. R. Lyons II

15. D. M. Matteo

16-17. P. T. Owen

18. T. L. Sams

19. P. A. Schrandt

20. Central Research Library

21. ER Central Document Management Center-RC

22. Office of Scientific and Technical Information, P.O. Box 62, Oak Ridge, TN 37831

23. V. L. Boston, DOE-ORO, P. O. Box 2001, Oak Ridge, TN 37831-8541

24. C. T. Williams, DOE-ORO, P. O. Box 2001, Oak Ridge, TN 37831-8541 